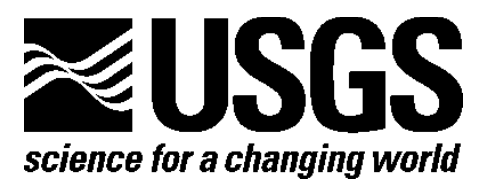

In cooperation with the City of Wichita

Preliminary Simulation of Chloride Transport in the Equus Beds Aquifer and Simulated Effects of Well Pumping and Artificial Recharge on Groundwater Flow and Chloride Transport near the City of Wichita, Kansas, 1990 through 2008

By Brian J. Klager, Brian P. Kelly, and Andrew C. Ziegler

Open-File Report 2014-1162

U.S. Department of the Interior

U.S. Geological Survey 


\section{U.S. Department of the Interior \\ SALLY JEWELL, Secretary}

\section{U.S. Geological Survey \\ Suzette M. Kimball, Acting Director}

U.S. Geological Survey, Reston, Virginia 2014

For product and ordering information:

World Wide Web: http://www.usgs.gov/pubprod

Telephone: 1-888-ASK-USGS

For more information on the USGS-the Federal source for science about the Earth, its natural and living resources, natural hazards, and the environment:

World Wide Web: http://www.usgs.gov

Telephone: 1-888-ASK-USGS

Suggested citation:

Klager, B.J., Kelly, B.P., and Ziegler, A.C., 2014, Preliminary simulation of chloride transport in the Equus Beds aquifer and simulated effects of well pumping and artificial recharge on groundwater flow and chloride transport near the city of Wichita, Kansas, 1990 through 2008: U.S. Geological Survey Open-File Report 2014-1162, 76 p., http://dx.doi.org/10.3133/ofr20141162

Any use of trade, product, or firm names is for descriptive purposes only and does not imply endorsement by the U.S. Government.

Although this report is in the public domain, permission must be secured from the individual copyright owners to reproduce any copyrighted material contained within this report.

ISSN 2331-1258 (online) 


\section{Contents}

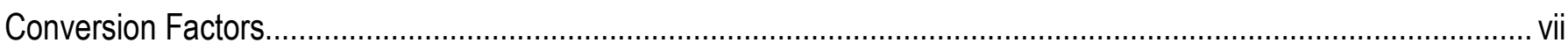

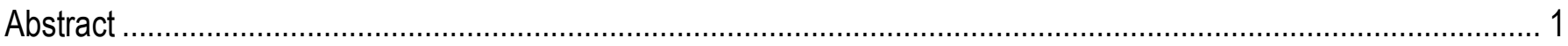

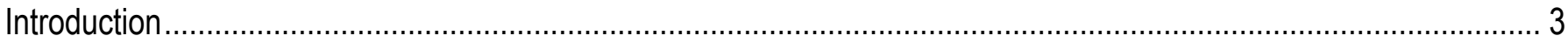

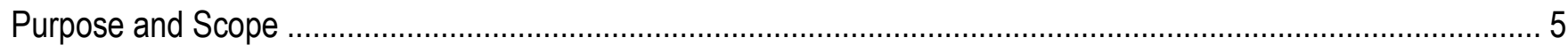

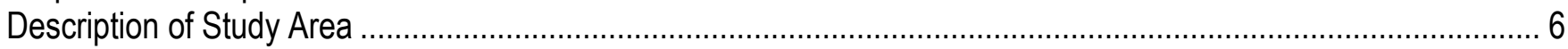

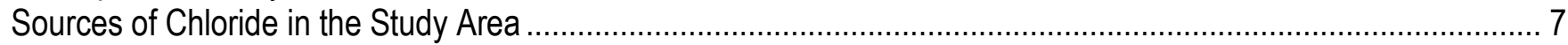

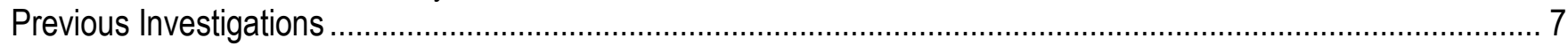

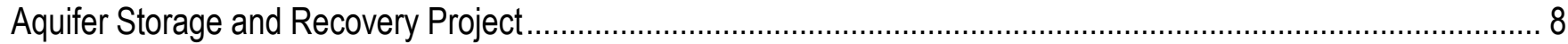

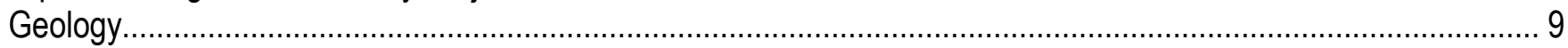

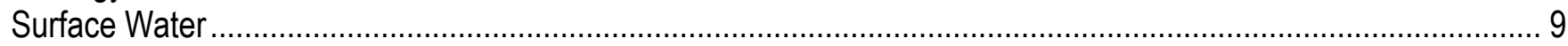

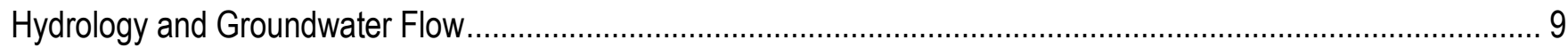

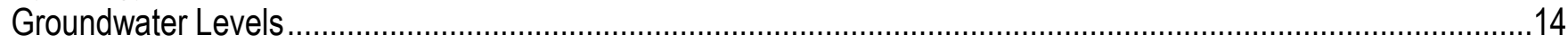

Groundwater-Flow and Chloride-Transport Directions in the Equus Beds Aquifer ...............................................14

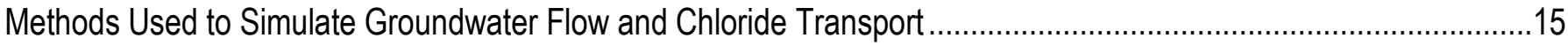

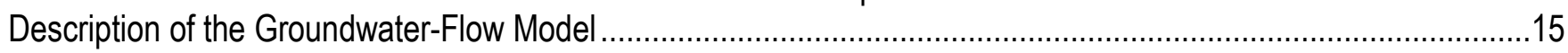

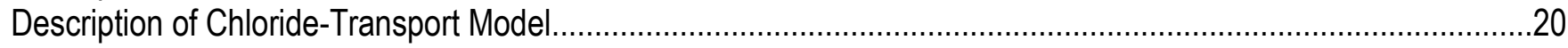

Modifications to Groundwater-Flow Model for Use with the Chloride-Transport Model .....................................21

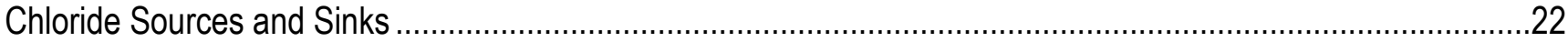

Chloride Concentrations in Groundwater used for the Initial Conditions in the Chloride-Transport Model ............23

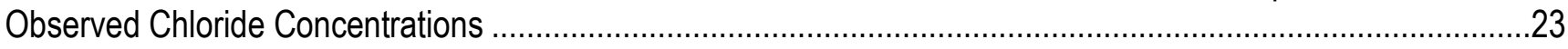

Analysis of Simulated Chloride-Concentration and Head Data .........................................................................

Model Limitations ......................................................................................................................

Description of Preliminary Simulation of Chloride Transport in the Equus Beds Aquifer with Existing Well Pumping and

Artificial Recharge.....................................................................................................................

Comparison of Observed Chloride Concentrations from 1990 through 2008 to Simulated Chloride Concentrations

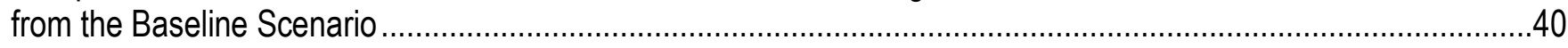

Potential Improvements to the Groundwater-Flow Model ........................................................................52

Simulated Effects of Hypothetical Well-Pumping and Artificial-Recharge Scenarios on Groundwater Flow and Chloride

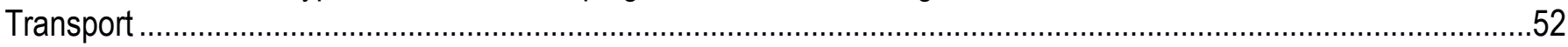

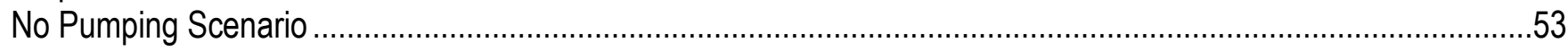

Double Wichita Municipal Pumping and Existing Irrigation Pumping Scenario .....................................................59

Existing Wichita Municipal Pumping and No Irrigation Pumping Scenario ..........................................................62

Double Wichita Municipal Pumping and No Irrigation Pumping Scenario ...........................................................63

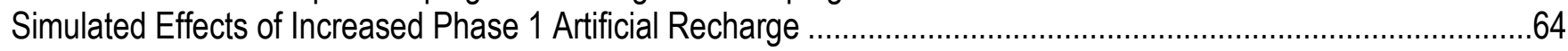

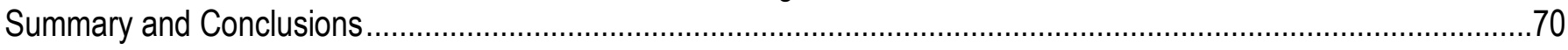

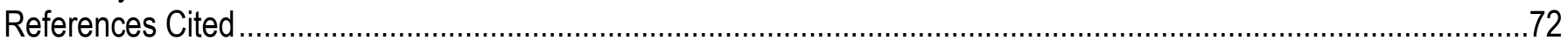

Appendix 1. - Videos of the Simulated Chloride Fronts where Concentrations Reach 250 Milligrams per Liter, Equus

Beds aquifer, Model Layers 1, 2, and 3, Stress Periods 1990-2008 ................................................................76 


\section{Figures}

Figure 1. Map showing location of study area (modified from Kelly and others, 2013). ........................................ 4

Figure 2. Map showing location of the Equus Beds Aquifer Storage and Recovery project................................. 10

Figure 3. Geologic sections for the Equus Beds aquifer in the study area..................................................... 11

Figure 4. Map showing locations of industrial, irrigation, and municipal wells in the model area........................... 12

Figure 5. Graphs showing amount of water pumped or recharged from the Equus Beds aquifer by industrial, irrigation, municipal withdrawal, artificial recharge and artificial withdrawal from wells in the study area. (A), 1939

through 2008. (B), 1990 through 2008. (C), cumulative-pumping rate 1939 through 2008....................................... 13

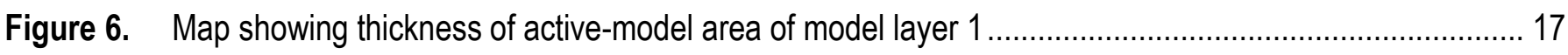

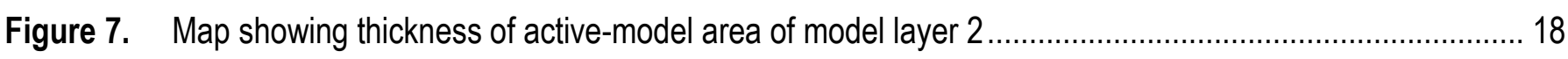

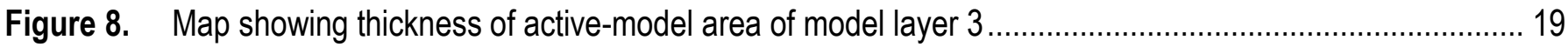

Figure 9. Map showing initial (1990) chloride distribution in and around the Wichita well field for model layer $1 \ldots 24$

Figure 10. Map showing initial (1990) chloride distribution in and around the Wichita well field for model layer 225

Figure 11. Map showing initial (1990) chloride distribution in and around the Wichita well field for model layer 326

Figure 12. Map showing locations of wells with chloride-concentration data in the study area, model layer 1 ,

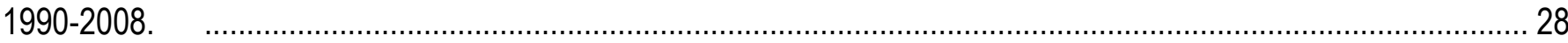

Figure 13. Map showing locations of wells with chloride-concentration data in the study area, model layer 2,

$1990-2008$.

Figure 14. Model showing locations of wells with chloride-concentration data in the study area, model layer 3 , 1990-2008.

Figure 15. Map of the end of 1990 stress period and end of 2008 stress period simulated chloride fronts for the existing pumping scenario, model layer 1 
Figure 16. Map of the end of 1990 stress period and end of 2008 stress period simulated chloride fronts for the existing pumping scenario, model layer 2 .

Figure 17. Map of the end of 1990 stress periods and end of 2008 stress periods simulated chloride fronts for the existing pumping scenario, model layer 3. 35

Figure 18. Map of simulated chloride front for baseline scenario from the end of the 2008 stress period and chloride front based on shallow chloride data from 2011, model layer 1. 38

Figure 19. Map of simulated chloride front for baseline scenario from the end of the 2008 stress period and chloride front based on deep chloride data from 2011, model layer 3. 39

Figure 20. Graph showing comparison of simulated chloride concentration to residuals of chloride concentration (simulated minus observed concentrations at each sample location), 1990 through 2008. 41

Figure 21. Map showing locations of monitoring wells in the Hollow-Nikkel area, model layer 3. 42

Figure 22. Graphs showing observed chloride concentrations and simulated chloride concentrations from the baseline scenario in monitoring wells in the Hollow-Nikkel area.

Figure 23. Graphs showing observed and simulated chloride concentrations for the baseline scenario for index monitoring wells between the Arkansas River and the southern boundary of the Wichita well field.

Figure 24. Graphs showing observed and simulated chloride concentrations for the baseline scenario for index monitoring wells near the Little Arkansas River in Halstead.

Figure 25. Graphs showing observed and simulated chloride concentrations for the baseline scenario for index monitoring wells near the Burrton plume. 50

Figure 26. End of 2008 simulated $250 \mathrm{mg} / \mathrm{L}$ chloride concentration contours for all scenarios, model layer $1 \ldots . .56$

Figure 27. End of 2008 simulated $250 \mathrm{mg} / \mathrm{L}$ chloride concentration contours for all scenarios, model layer $2 \ldots . \ldots 5$ Figure 28. End of 2008 simulated $250 \mathrm{mg} / \mathrm{L}$ chloride concentration contours for all scenarios, model layer $3 \ldots 58$ Figure 29. Simulated chloride fronts near Burrton, Kansas for baseline and increased Phase 1 artificial recharge scenarios, end of 2008 stress period, model layer 1 
Figure 30. Simulated chloride fronts near Burrton, Kansas for baseline and increased Phase 1 artificial recharge

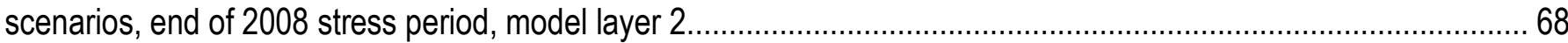

Figure 31. Simulated chloride fronts near Burrton, Kansas for baseline and increased Phase 1 artificial recharge scenarios, end of 2008 stress period, model layer 3.

\section{Tables}

Table 1. Number of chloride samples analyzed per model layer in each stress period.

Table 2. Estimated average rates of movement of simulated chloride fronts for each scenario and distance between simulated chloride fronts in baseline and hypothetical scenarios at the end of the 2008 stress period.

Table 3. Pumping and recharge rates for each model scenario.

Table 4. Simulated water level differences between hypothetical scenarios and the baseline scenario in index monitoring wells at the end of the 2008 stress period.

Table 5. Simulated storage volume difference between hypothetical scenarios and baseline scenario in the basin storage area, end of 2008 stress period. 61

Table 6. Simulated artificial recharge rates for the Phase 1 sites in the increased artificial recharge scenario. .... 65 


\section{Conversion Factors}

Inch/Pound to SI

\begin{tabular}{|c|c|c|}
\hline Multiply & By & To obtain \\
\hline \multicolumn{3}{|c|}{ Length } \\
\hline foot (ft) & 0.3048 & meter $(\mathrm{m})$ \\
\hline mile (mi) & 1.609 & kilometer $(\mathrm{km})$ \\
\hline \multicolumn{3}{|c|}{ Area } \\
\hline acre & 4,047 & square meter $\left(\mathrm{m}^{2}\right)$ \\
\hline acre & 0.004047 & square kilometer $\left(\mathrm{km}^{2}\right)$ \\
\hline square foot $\left(\mathrm{ft}^{2}\right)$ & 929.0 & square centimeter $\left(\mathrm{cm}^{2}\right)$ \\
\hline $\begin{array}{l}\text { square foot }\left(\mathrm{ft}^{2}\right) \\
\text { square mile }\left(\mathrm{mi}^{2}\right)\end{array}$ & $\begin{array}{l}0.09290 \\
2.590\end{array}$ & $\begin{array}{l}\text { square meter }\left(\mathrm{m}^{2}\right) \\
\text { square kilometer }\left(\mathrm{km}^{2}\right)\end{array}$ \\
\hline \multicolumn{3}{|c|}{ Volume } \\
\hline acre-foot (acre-ft) & 1,233 & cubic meter $\left(\mathrm{m}^{3}\right)$ \\
\hline $\begin{array}{l}\text { barrel }(\mathrm{bbl}),(\text { petroleum, } \\
1 \text { barrel }=42 \text { gal) } \\
\text { cubic foot }\left(\mathrm{ft}^{3}\right)\end{array}$ & $\begin{array}{l}0.1590 \\
0.02832\end{array}$ & $\begin{array}{l}\text { cubic meter }\left(\mathrm{m}^{3}\right) \\
\text { cubic meter }\left(\mathrm{m}^{3}\right)\end{array}$ \\
\hline \multicolumn{3}{|c|}{ Flow rate } \\
\hline $\begin{array}{l}\text { foot per year (ft/yr) } \\
\text { acre-foot per day (acre-ft/d) }\end{array}$ & $\begin{array}{l}0.3048 \\
0.01427\end{array}$ & $\begin{array}{l}\text { meter per year }(\mathrm{m} / \mathrm{yr}) \\
\text { cubic meter per second }\left(\mathrm{m}^{3} / \mathrm{s}\right)\end{array}$ \\
\hline acre-foot per year (acre-ft/yr) & 1,233 & cubic meter per year $\left(\mathrm{m}^{3} / \mathrm{yr}\right)$ \\
\hline acre-foot per year (acre-ft/yr) & 0.001233 & $\begin{array}{l}\text { cubic hectometer per year } \\
\left(\mathrm{hm}^{3} / \mathrm{yr}\right)\end{array}$ \\
\hline cubic foot per second $\left(\mathrm{ft}^{3} / \mathrm{s}\right)$ & 0.02832 & cubic meter per second $\left(\mathrm{m}^{3} / \mathrm{s}\right)$ \\
\hline million gallons per day (Mgal/d) & 0.04381 & cubic meter per second $\left(\mathrm{m}^{3} / \mathrm{s}\right)$ \\
\hline \multicolumn{3}{|c|}{ Density } \\
\hline pound per cubic foot $\left(\mathrm{lb} / \mathrm{ft}^{3}\right)$ & 16020 & milligram per liter $(\mathrm{mg} / \mathrm{L})$ \\
\hline \multicolumn{3}{|c|}{ Hydraulic conductivity* } \\
\hline foot per day (ft/d) & 0.3048 & meter per day $(\mathrm{m} / \mathrm{d})$ \\
\hline \multicolumn{3}{|c|}{ Hydraulic gradient } \\
\hline foot per mile ( $\mathrm{ft} / \mathrm{mi})$ & 0.1894 & meter per kilometer $(\mathrm{m} / \mathrm{km})$ \\
\hline \multicolumn{3}{|c|}{ Mass } \\
\hline ton & 907.2 & kilogram (kg) \\
\hline
\end{tabular}

Temperature in degrees Celsius $\left({ }^{\circ} \mathrm{C}\right)$ may be converted to degrees Fahrenheit $\left({ }^{\circ} \mathrm{F}\right)$ as follows:

${ }^{\circ} \mathrm{F}=\left(1.8 \mathrm{x}^{\circ} \mathrm{C}\right)+32$

Temperature in degrees Fahrenheit $\left({ }^{\circ} \mathrm{F}\right)$ may be converted to degrees Celsius $\left({ }^{\circ} \mathrm{C}\right)$ as follows:

${ }^{\circ} \mathrm{C}=\left({ }^{\circ} \mathrm{F}-32\right) / 1.8$

Vertical coordinate information is referenced to the North American Vertical Datum of 1988 (NAVD 88)

Horizontal coordinate information is referenced to the North American Datum of 1983 (NAD 83)

Altitude, as used in this report, refers to distance above the vertical datum. 
* Hydraulic conductivity: The standard unit for hydraulic conductivity is cubic foot per day per square foot [(ft $\left./ \mathrm{d}) / \mathrm{ft}^{2}\right]$. In this report, the mathematically reduced form, foot per day (ft/d), is used for convenience. 


\title{
Preliminary Simulation of Chloride Transport in the Equus Beds Aquifer and Simulated Effects of Well Pumping and Artificial Recharge on Groundwater Flow and Chloride Transport near the City of Wichita, Kansas, 1990 through 2008
}

\author{
By Brian J. Klager, Brian P. Kelly, and Andrew C. Ziegler
}

\begin{abstract}
The Equus Beds aquifer in south-central Kansas is a primary water-supply source for the city of Wichita. Water-level declines because of groundwater pumping for municipal and irrigation needs as well as sporadic drought conditions have caused concern about the adequacy of the Equus Beds aquifer as a future water supply for Wichita. In March 2006, the city of Wichita began construction of the Equus Beds Aquifer Storage and Recovery project, a plan to artificially recharge the aquifer with excess water from the Little Arkansas River. Artificial recharge will raise groundwater levels, increase storage volume in the aquifer, and deter or slow down a plume of chloride brine approaching the Wichita well field from the Burrton, Kansas area caused by oil production activities in the 1930s. Another source of high chloride water to the aquifer is the Arkansas River. This study was prepared in cooperation with the city of Wichita as part of the Equus Beds Aquifer Storage and Recovery project.

Chloride transport in the Equus Beds aquifer was simulated between the Arkansas and Little Arkansas Rivers near the Wichita well field. Chloride transport was simulated for the Equus Beds aquifer using SEAWAT, a computer program that combines the groundwater-flow model MODFLOW2000 and the solute-transport model MT3DMS. The chloride-transport model was used to simulate the period from 1990 through 2008 and the effects of five well pumping scenarios and one artificial recharge scenario. The chloride distribution in the aquifer for the beginning of 1990 was interpolated from groundwater samples from around that time, and the chloride concentrations in rivers for the study period were interpolated from surface water samples.

Five well-pumping scenarios and one artificial-recharge scenario were assessed for their effects on simulated chloride transport and water levels in and around the Wichita well field. The scenarios were: (1) existing 1990 through 2008 pumping conditions, to serve as a baseline scenario for comparison with the hypothetical scenarios; (2) no pumping in the model area, to demonstrate the chloride movement without the influence of well pumping; (3) double municipal pumping from the Wichita well field with existing irrigation pumping; (4) existing municipal pumping with no irrigation pumping in the model area; (5) double municipal pumping in the Wichita well field and no irrigation pumping in the model area; and (6) increasing artificial recharge to the Phase 1 Artificial Storage and Recovery project sites by 2,300 acre-feet per year.
\end{abstract}


The effects of the hypothetical pumping and artificial recharge scenarios on simulated chloride transport were measured by comparing the rate of movement of the 250-milligrams-per-liter-chloride front for each hypothetical scenario with the baseline scenario at the Arkansas River area near the southern part of the Wichita well field and the Burrton plume area. The scenarios that increased the rate of movement the most compared to the baseline scenario of existing pumping between the Arkansas River and the southern boundary of the well field were those that doubled the city of Wichita's pumping from the well field (scenarios 3 and 5), increasing the rate of movement by 50 to 150 feet per year, with the highest rate increases in the shallow layer and the lowest rate increases in the deepest layer. The no pumping and no irrigation pumping scenarios ( 2 and 4) slowed the rate of movement in this area by 150 to 210 feet per year and 40 to 70 feet per year, respectively. In the double Wichita pumping scenario (3), the rate of movement in the shallow layer of the Burrton area decreased by about 50 feet per year. Simulated chloride rate of movement in the deeper layers of the Burrton area was decreased in the no pumping and no irrigation scenarios (2 and 4) by 80 to 120 feet per year and 50 feet per year, respectively, and increased in the scenarios that double Wichita's pumping ( 3 and 5) from the well field by zero to 130 feet per year, with the largest increases in the deepest layer. In the increased Phase 1 artificial recharge scenario (6), the rate of chloride movement in the Burrton area increased in the shallow layer by about 30 feet per year, and decreased in the middle and deepest layer by about 10 and 60 feet per year, respectively. Comparisons of the rate of movement of the simulated 250-milligramsper-liter-chloride front in the hypothetical scenarios to the baseline scenario indicated that, in general, increases to pumping in the well field area increased the rate of simulated chloride movement toward the well field area by as much as 150 feet per year. Reductions in pumping slowed the advance of chloride toward the well field by as much as 210 feet per year, although reductions did not stop the movement of chloride toward the well field, including when pumping rates were eliminated. If pumping is completely discontinued, the rate of chloride movement is about 500 to 600 feet per year in the area between the Arkansas River and the southern part of the Wichita well field, and 70 to 500 feet per year in the area near Burrton with the highest rate of movement in the shallow aquifer layer.

The averages of simulated water-levels in index monitoring wells in the Wichita well field at the end of 2008 were calculated for each scenario. Compared to the baseline scenario, the average simulated water level was 5.05 feet higher for the no pumping scenario, 4.72 feet lower for the double Wichita pumping with existing irrigation scenario, 2.49 feet higher for the no irrigation pumping with existing Wichita pumping scenario, 1.53 feet lower for the double Wichita pumping with no irrigation scenario, and 0.48 feet higher for the increased Phase 1 artificial recharge scenario.

The groundwater flow was simulated with a preexisting groundwater-flow model, which was not altered to calibrate the solute-transport model to observed chloride-concentration data. Therefore, some areas in the model had poor fit between simulated chloride concentrations and observed chloride concentrations, including the area between Arkansas River and the southern part of the Wichita well field, and the Hollow-Nikkel area about 6 miles north of Burrton. Compared to the interpreted location of the 250-milligrams per liter-chloride front based on data collected in 2011, in the Arkansas River area the simulated 250-milligrams per liter-chloride front moved from the river toward the well field about twice the rate of the actual 250-milligrams per liter-chloride front in the shallow layer and about four times the rate of the actual 250-milligrams per liter-chloride front in the deep layer. Future groundwaterflow and chloride-transport modeling efforts may achieve better agreement between observed and simulated chloride concentrations in these areas by taking the chloride-transport model fit into account when adjusting parameters such as hydraulic conductivity, riverbed conductance, and effective porosity during calibration. 
Results of the hypothetical scenarios simulated indicate that the Burrton chloride plume will continue moving toward the well field regardless of pumping in the area and that one alternative may be to increase pumping from within the plume area to reverse the groundwater-flow gradients and remove the plume. Additionally, the results of modeling these scenarios indicate that eastward movement of the Burrton plume could be slowed by the additional artificial recharge at the Phase 1 sites and that decreasing pumping along the Arkansas River or increasing water levels could retard the movement of chloride and may prevent further encroachment into the southern part of the well field area.

\section{Introduction}

The Equus Beds aquifer is a primary water-supply source for Wichita, Kansas, and the surrounding area because of shallow depth to water, large saturated thickness, and generally good water quality (Myers and others, 1996; Hansen and Aucott, 2003, Ziegler and others, 1999). From 1995 through 2005, 31 to 49 percent of the city water supply was withdrawn from the aquifer (Ziegler and others, 2010). Substantial water-level declines in the Equus Beds aquifer resulted from pumping groundwater for agricultural and municipal needs since development of the Wichita well field (WWF) began in the 1940s; additionally, water levels decreased because recharge to the aquifer decreased during periodic drought conditions. The lowest water levels in the aquifer were recorded in October 1992 and, in some locations, were as much as 50 feet (ft) lower than the predevelopment (1940) water levels (Hansen and Aucott, 2001, 2004, 2010; Hansen, 2007). These water-level declines caused concern about the adequacy of the aquifer as a future water supply for Wichita.

Another concern about the city water supply is increases in dissolved solids, as indicated by increasing dissolved chloride concentrations (hereinafter referred to as chloride) caused by the migration of high chloride waters toward the WWF. Sources of chloride to the groundwater include the Arkansas River to the southwest of the WWF, oil-field brines that leaked from surface disposal pits and injection wells in and near the Burrton oil field (fig. 1), municipal wastewater treatment facility discharges, and mineralized water from the underlying Wellington Formation (Ziegler and others, 1999; Whittemore, 2007). Declining water levels also may accelerate migration of oil-field brine from the Burrton oil field to the northwest of the WWF and water from the Arkansas River with elevated dissolved solids concentrations (southwest of the WWF) into the freshwater of the Equus Beds aquifer (fig. 1) (Hansen, 2007). In March 2006, the city of Wichita began construction of the Equus Beds Aquifer Storage and Recovery (ASR) project, a plan to artificially recharge the aquifer with excess surface-water flow from the Little Arkansas River. The artificially recharged water will raise groundwater levels in the aquifer, which will increase the volume of water in the aquifer for later recovery and deter or slow movement into the WWF of the brine plume near Burrton, Kansas, and of the high chloride water in the Arkansas River. Phase 1 facilities for this project started operating in 2007 and have a treatment capacity of about 7 million gallons per day (Mgal/d). Phase 2 facilities were completed in 2011 and started operating in 2013. The combined treatment capacity for Phase 1 and 2 facilities is about $40 \mathrm{Mgal} / \mathrm{d}$ (Desilva and Ary, 2011). 


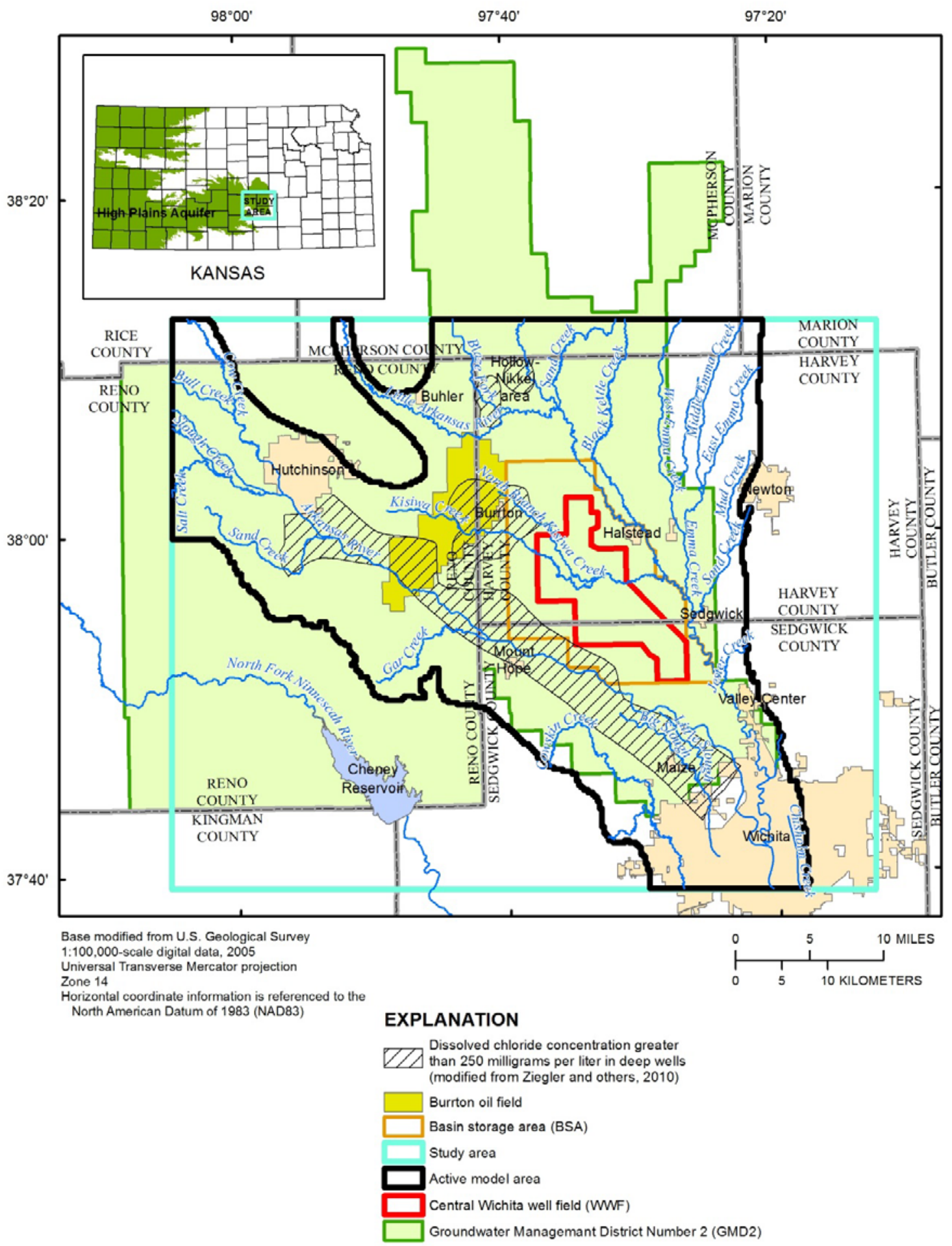

Figure 1. Map showing location of study area (modified from Kelly and others, 2013). 
The WWF was developed in the Equus Beds aquifer during the 1940s and 1950s within the area labeled as Central Wichita well field in figure 1. As of 2008, 55 active production wells that provide about 40 percent of the water-supply for the city of Wichita were completed in the aquifer (Debra Ary, city of Wichita, oral commun., 2010). In 1965, the city of Wichita also began using water from Cheney Reservoir to supplement its supply from the Equus Beds aquifer. The proportion of the water obtained from Cheney Reservoir increased from 20 percent in 1965 to 44 percent in 1994, and during 1995 through 2005, water from Cheney Reservoir provided 51 to 69 percent of Wichita's water supply (Ziegler and others, 2010). The increased reliance on surface water from Cheney Reservoir was part of Wichita's Integrated Local Water Supply Plan, implemented in 1993 (Wichita, 2013), and described in the Integrated Resource Plan in Warren and others (1995). The purpose of this plan was to ensure that the city water-supply needs are met through 2050 by promoting conservation, increasing water use from Cheney Reservoir, and decreasing reliance on water from city wells in the WWF.

In October 2009, the U.S. Geological Survey (USGS), in cooperation with the city of Wichita and as part of the ASR project, began a study to determine groundwater flow in the area of the WWF and chloride transport from the Arkansas River and Burrton oil field to the WWF. The primary study area includes the Equus Beds aquifer near the city of Wichita supply wells and the Aquifer Storage and Recovery project Phase 1 and 2 artificial recharge areas. Data from existing groundwater-flow models (Spinazola and others, 1985; Myers and others, 1996; Pruitt, 1993) and 2008 lithologic and hydrologic data were used to construct a model to simulate groundwater flow in the Equus Beds aquifer (Kelly and others, 2013).

Drought conditions during 2010 through 2013 and continued use of Cheney Reservoir to supply water to the city of Wichita lowered water levels in Cheney Reservoir by as much as $8.06 \mathrm{ft}$ below the top of the conservation pool and reduced the amount of water available from the reservoir (U.S. Geological Survey, 2014a). In anticipation of continued drought, the city of Wichita has proposed increasing groundwater withdrawals and decreasing use of Cheney Reservoir to meet its water-supply needs.

Increased pumping from the WWF will reduce groundwater levels locally and may increase the rate of chloride transport toward the WWF. Because of this concern, the effects of proposed changes to pumping from the WWF on chloride transport and groundwater flow and levels were assessed using the groundwater-flow model developed by Kelly and others (2013) with the addition of a chloride-transport simulation developed using the groundwater-flow and solute-transport model SEAWAT (Langevin and others, 2008).

\section{Purpose and Scope}

The purpose of the report is to describe the preliminary simulation of chloride transport (1990 through 2008) in the Equus Beds aquifer between the Arkansas and Little Arkansas Rivers near the city of Wichita well field; compare simulated and observed chloride concentrations to help evaluate the calibration of the groundwater-flow and chloride-transport model and to evaluate areas of poor model fit; and last, present the effects of hypothetical well-pumping and artificial-recharge scenarios on the simulated chloride transport and groundwater levels. This report presents information that is part of a long-term cooperative study (since 1940) between the city of Wichita and the USGS to describe the water quantity conditions in the Equus Beds aquifer and the Little Arkansas River and, more recently (1995 to present), the potential effects of artificial recharge on water resources in south-central Kansas.

The simulations of groundwater flow and chloride transport described in this report are based on a variable-density groundwater-flow and chloride-transport model of the Equus Beds aquifer. Input data for the groundwater flow are from a previously calibrated model (Kelly and others, 2013). Chloride data 
used as model input were collected from 1985 through 2008 by the USGS and Equus Beds Groundwater Management District No. 2 (GMD2) as part of water-quality monitoring and the Equus Beds Groundwater Recharge Demonstration and ASR projects.

As a purpose of this report, simulated effects of hypothetical well pumping and artificial recharge scenarios for 1990 through 2008 are evaluated. The effects of varying the magnitudes of municipal and irrigation well pumping on chloride transport and groundwater levels are evaluated for six scenarios in the study area:

1. Existing pumping (1990 through 2008);

2. Eliminating all pumping;

3. Doubling the rate of the city of Wichita's municipal-well pumping from the WWF with existing irrigation-pumping rates;

4. Existing municipal-well pumping rates and eliminating irrigation pumping rates;

5. Doubling Wichita's municipal-well pumping rates from the WWF and eliminating irrigationpumping rates, and

6. Increasing recharge at Phase 1 ASR project sites and not changing the existing pumping rates.

This report also includes contour maps which allow comparisons of the simulated chloride fronts where chloride concentrations reach 250 milligrams per liter $(\mathrm{mg} / \mathrm{L})$ (referred to hereinafter as the chloride front) for each scenario for three model layers of the Equus Beds aquifer. A chloride concentration of $250 \mathrm{mg} / \mathrm{L}$ was used in the analysis because it is the U.S. Environmental Protection Agency Secondary Maximum Contaminant Level (SMCL) for chloride in public water supplies (U.S. Environmental Protection Agency, 2013).

\section{Description of Study Area}

The study area consists of 1,844 square miles in Harvey, Kingman, Marion, McPherson, Reno, Rice, and Sedgwick Counties in south-central Kansas (fig. 1). Most of the study area is within GMD2 and includes the major cities of Hutchinson and Wichita (fig. 1). Smaller cities within the study area include Burrton, Halstead, Newton, Sedgwick, and Valley Center. The study area lies in the Arkansas River section of the Central Lowland physiographic province (Schoewe, 1949) and has little relief except for an area of sand dunes north and northeast of Hutchinson. The land slopes gently toward the major streams in the area (Schoewe, 1949). Land-surface altitudes range from 1,270 to 1,650 $\mathrm{ft}$ above the North American Vertical Datum of 1988 (NAVD 88) and generally slope from northwest to southeast. The two major rivers that flow through the area, the Arkansas and the Little Arkansas Rivers, flow from northwest to southeast.

The study area has a continental climate with large variations in seasonal temperatures. Temperature extremes for the period of weather records at Wichita, Kansas range from more than 110 degrees to less than -20 degrees Fahrenheit $\left({ }^{\circ} \mathrm{F}\right)$. Temperatures above $90{ }^{\circ} \mathrm{F}$ occur on average for 63 days per year, whereas cold temperatures below $0{ }^{\circ} \mathrm{F}$ occur about 2 days per year (National Oceanic and Atmospheric Administration, 2008). Mean annual precipitation at Wichita is about 30 inches (in). Most precipitation occurs during spring and summer. More than 50 in. were recorded in the wettest years, whereas less than 15 in. of precipitation were recorded in the driest years (National Oceanic and Atmospheric Administration, 2008).

The easternmost extension of the High Plains aquifer system consists of alluvial deposits of sand and gravel interbedded with clay or silt (Williams and Lohman, 1949), and is commonly referred to as the Equus Beds aquifer because Pleistocene-aged horse fossils are present in the aquifer. The Equus 
Beds aquifer is unconfined in the study area (Spinazola and others, 1985) and is a substantial watersupply for Wichita, Kansas and the surrounding area because of its shallow depth to water-as shallow as 10 feet (ft) near the Arkansas River. In this area, the aquifer has a saturated thickness of as much as $250 \mathrm{ft}$ (Myers and others, 1996; Hansen and Aucott, 2003) and generally has good water quality (Ziegler and others, 1999). The general direction of groundwater movement within the study area is to the east (Aucott and Myers, 1998).

\section{Sources of Chloride in the Study Area}

The Arkansas River contains high concentrations of chloride, much of which is probably from salt marshes along tributaries upstream from Hutchinson, Kansas (Williams, 1946). Chloride samples collected by the USGS and the Kansas Department of Health and Environment (KDHE) during 1990 through 2008 at river sites in the model area commonly exceeded $500 \mathrm{mg} / \mathrm{L}$ and occasionally exceeded $1,000 \mathrm{mg} / \mathrm{L}$. When the river is losing water to the aquifer, these high chloride concentrations can infiltrate into the aquifer. As a result, the Arkansas River is one of the primary sources of chloride that affects the quality of groundwater near the WWF (Ziegler and others, 2010).

Extensive salt deposits are commercially mined in the study area. Rock salt was first discovered in central Kansas in 1887 (Sawin and Buchanan, 2002). Several shaft mines and solution mines have been developed in Reno and Sedgwick Counties. In 2000, salt mines in Kansas produced 2,944,000 tons of rock salt, 75 percent of which is mined in Reno County (Bayne, 1956; Sawin and Buchanan, 2002).

Additionally, oil and natural gas production is an important industry in the study area. Cumulative oil production in Harvey, Reno, and Sedgwick Counties is over 255 million barrels (bbl) and cumulative natural gas production is over 136 million Mcf (where one Mcf equals one thousand cubic feet) (Kansas Geological Survey, 2011). In the 1930s, an oil field was developed near the town of Burrton in western Harvey County. Brine, coproduced during oil production, was discharged to ponds; brine leaked into the ground and contaminated the aquifer. Before oil-field development, chloride concentrations in the groundwater from the Equus Beds aquifer generally were less that $50 \mathrm{mg} / \mathrm{L}$ (Whittemore, 2007). By 1948, chloride concentrations in the shallow parts of the aquifer around the Burrton oil field were greater than $250 \mathrm{mg} / \mathrm{L}$ because of contamination by oil-field brine (Whittemore, 2007).

Concern over deteriorating quality of groundwater in the aquifer because of high chloride concentrations led the Kansas Department of Agriculture - Division of Water Resources (KDA-DWR) to establish the Burrton Intensive Groundwater Use Control Area (IGUCA) in 1984. Applications for groundwater use within the IGUCA are reviewed for potential effects on water-level drawdowns and movement of a brine plume in the aquifer (Burrton Task Force, 1984).

\section{Previous Investigations}

Previous studies investigated chloride transport in the Equus Beds aquifer. Sophocleous (1984) developed a calibrated model of groundwater flow and a chloride-transport model, which indicated that the direction of movement of the brine plume from the Burrton area, hereinafter referred to as the "Burrton plume," was to the southeast, toward the WWF. However, the simulations determined that water quality near the well field would not deteriorate because of high chloride concentrations by the year 2000. Spinazola and others (1985) used a two-dimensional, finite-difference, solute-transport model to simulate the effects that future groundwater withdrawals might have on the chloride concentrations in the aquifer from 1980 to 2020. They projected the effects of three pumping scenarios: (1) half of the 1971-79 pumping rates, (2) continued 1971-79 pumping rates, and (3) double the 1971-79 
pumping rates. The increase in chloride concentration for all scenarios was proportional to the pumping rates. Chloride concentrations increased by 20 to $45 \mathrm{mg} / \mathrm{L}$ in the southern part of the WWF when the rates were decreased by one-half, and chloride concentrations increased by 90 to $450 \mathrm{mg} / \mathrm{L}$ in the southern part of the well field when the pumping rates doubled. Myers and others (1996) used a groundwater-flow model and a particle-tracking program to simulate movement of chloride between the Arkansas River and the Equus Beds aquifer and predicted a chloride load from the river to the aquifer would range from 110 to 200 tons per day (ton/d) by the year 2019. Particle-tracking simulations indicated chloride movement from the river into the aquifer and then groundwater would flow northward toward the WWF.

\section{Aquifer Storage and Recovery Project}

The purpose of the Equus Beds aquifer ASR project is to artificially recharge the aquifer with excess water from the Little Arkansas River to raise groundwater levels, increase storage volume in the aquifer for later use, and impede the movement of the Burrton plume toward the WWF (fig. 1). Stramel (1956, 1962a, 1962b, 1967) originally proposed to artificially recharge the Equus Beds aquifer with streamflow from runoff during periods of abundant precipitation. This artificially recharged water then could be used during periods of drought. Stramel (1956) also proposed using a variety of techniques to artificially recharge the aquifer, including water spreading, recharge pits or ponds, recharge wells, and induced recharge from streams by pumping. Additionally, Stramel (1962b) suggested investigation of the relation between streamflow or stage and water quality for the Arkansas River, Little Arkansas River, and Kisiwa Creek as sources for artificial recharge. Wichita's Integrated Local Water Supply Plan (Wichita, 2013) also calls for investigation of the use of water from the Little Arkansas River (when streamflow is greater than base flow) to recharge the Equus Beds aquifer.

The city of Wichita initiated the Equus Beds Groundwater Recharge Demonstration project in 1995 to test artificial recharge as a method for increasing water supply and preventing water-quality degradation (Ziegler and others, 1999). Water from the Little Arkansas River was diverted at sites near the towns of Halstead and Sedgwick for the Equus Beds Groundwater Recharge Demonstration project (Ziegler and others, 1999; Schmidt and others, 2007). At the Halstead recharge site, water was pumped from bank storage wells near the Little Arkansas River and recharged to the aquifer through recharge basins, trenches, or injection wells. At the Sedgwick recharge site, water was recharged to the aquifer by withdrawing water from the Little Arkansas River, treating the water to decrease turbidity and total fecal-coliform bacteria and to remove organic compounds, and then putting the water in recharge basins where it could infiltrate into the aquifer.

In March 2006, the city of Wichita followed up the success of the Equus Beds Groundwater Recharge Demonstration project by starting construction of the Equus Beds ASR project to artificially recharge the Equus Beds aquifer on a larger scale. Phase 1 of the ASR project was completed in 2006 and large-scale artificial recharge of the aquifer began at the Phase 1 sites in March 2007. The Phase 1 sites (fig. 2) use water from the Little Arkansas River - pumped directly from the river or from wells completed in the riverbank that indirectly pump from the river - as the source of artificial recharge to the Equus Beds aquifer. The water diverted from the Little Arkansas River and its alluvial aquifer for artificial recharge is allowed only when flows in the river are greater than minimums set by the State of Kansas (Kansas Department of Agriculture, Division of Water Resources, 2007).

The city of Wichita receives recharge credits for aquifer storage volume increase because of artificial recharge. A basin storage area (BSA, fig. 1) divided into 38 smaller areas, called index cells (fig. 2), was defined by the city of Wichita, and groundwater-flow models have been used to calculate the recharge credits for each index cell (Burns and McDonnell, 2008, 2009; Kelly and others, 2013). 
Recharge credits indicate the volume of water the city has recharged to the aquifer, the amount of water that moved between index cells, and the amount of water the city can remove at a later date from index cells that contain recharged water. For each index cell, the groundwater models were used to determine the effect of natural and artificial recharge, groundwater inflow and outflow, evaporation and transpiration, groundwater diversions from wells, infiltration and discharge to streams, calculated recharge credits, and surface water diversions.

\section{Geology}

The Equus beds consist of unconsolidated sand, silt, and gravel deposits that are located in the Arkansas River Lowlands and Wellington-McPherson Lowlands (Zeller, 1968) and are as much as 330 $\mathrm{ft}$ thick in the study area (Kelly and others, 2013). Eolian deposits occur in the northern part of the study area adjacent to the Arkansas and Little Arkansas Rivers. The deposits are composed of well sorted, moderately well rounded, fine to medium sand and locally include clay and silt.

The Equus Beds aquifer consists primarily of sand and gravel interbedded with clay or silt but locally may consist primarily of clay with thin sand and gravel layers (Lane and Miller, 1965a; Myers and others, 1996). The middle part of the beds generally has more fine-grained material than the deep and shallow parts (fig. 3) (Lane and Miller, 1965b; Myers and others, 1996); however, areas of high hydraulic conductivity exist in all parts of the aquifer. The Equus beds overlie the Wellington Formation which forms the confining units below the Equus beds.

\section{Surface Water}

Streams in the study area that are simulated in the groundwater-flow model are the Arkansas and Little Arkansas Rivers, and tributaries including Big Slough, Black Kettle, Blaze Fork, Bull, Chisholm, Cow, Cowskin, Emma, Gar, Jester, Kisiwa, Little Slough, Salt, Sand (there are two Sand Creeks - both are simulated), Slough, and Turkey Creeks (fig. 1). The major streams are hydraulically connected to the aquifer. Within the study area, the Arkansas River is hydraulically connected to the aquifer and, depending on streamflow, recharge, and well pumping, can be a gaining or a losing stream. The Little Arkansas River primarily is a gaining stream within the study area. The minor streams typically are gaining streams, but sometimes go dry if the groundwater level drops below the riverbed elevation.

\section{Hydrology and Groundwater Flow}

Groundwater flow in the Equus Beds aquifer is affected largely by the hydraulic properties of the aquifer material, areal recharge, well pumping, interactions with streams, and evapotranspiration. These processes and properties are described in detail in Kelly and others, (2013) and are summarized later in this report in the section "Description of the Groundwater-Flow Model." 


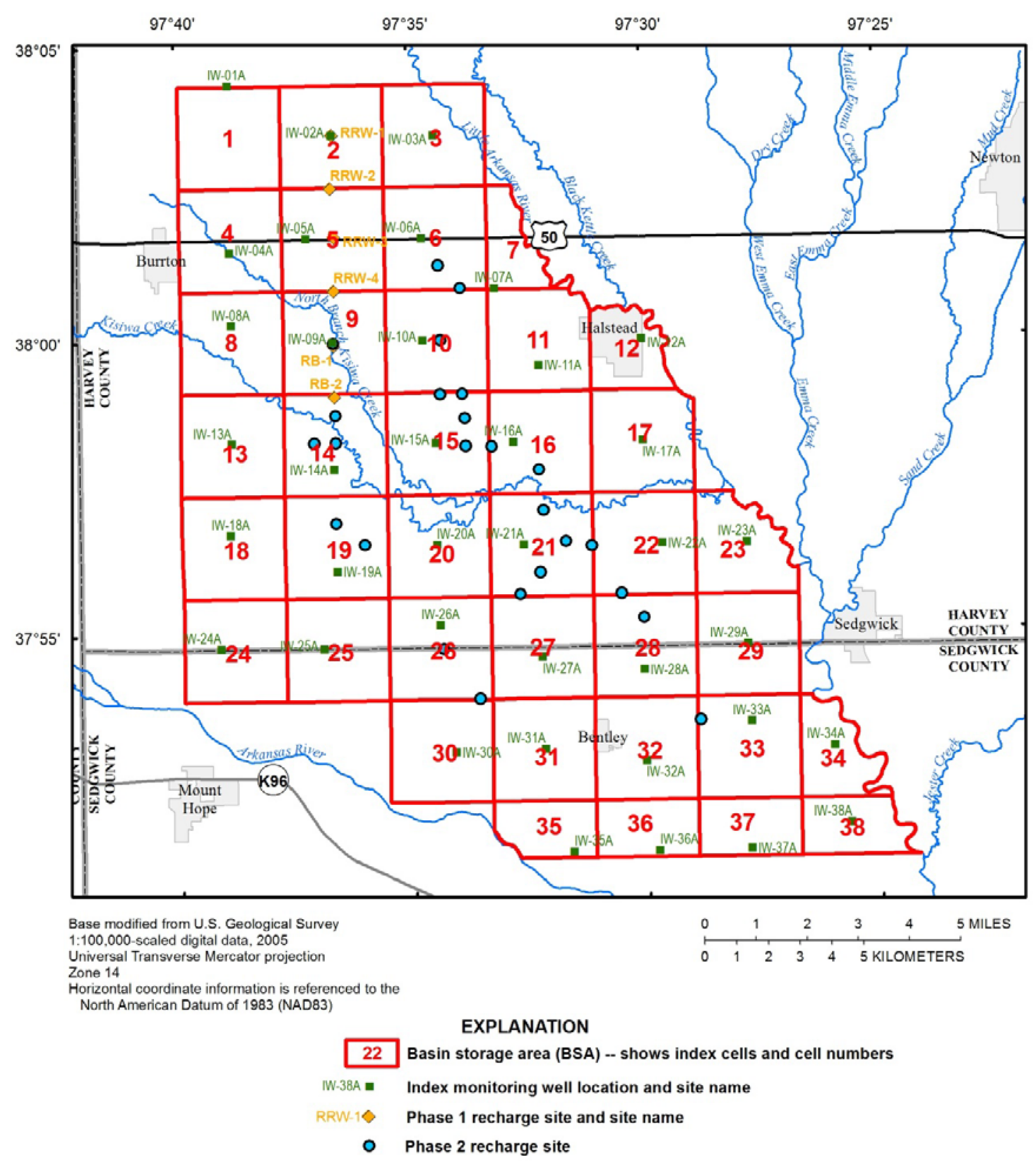

Figure 2. Map showing location of the Equus Beds Aquifer Storage and Recovery project. 

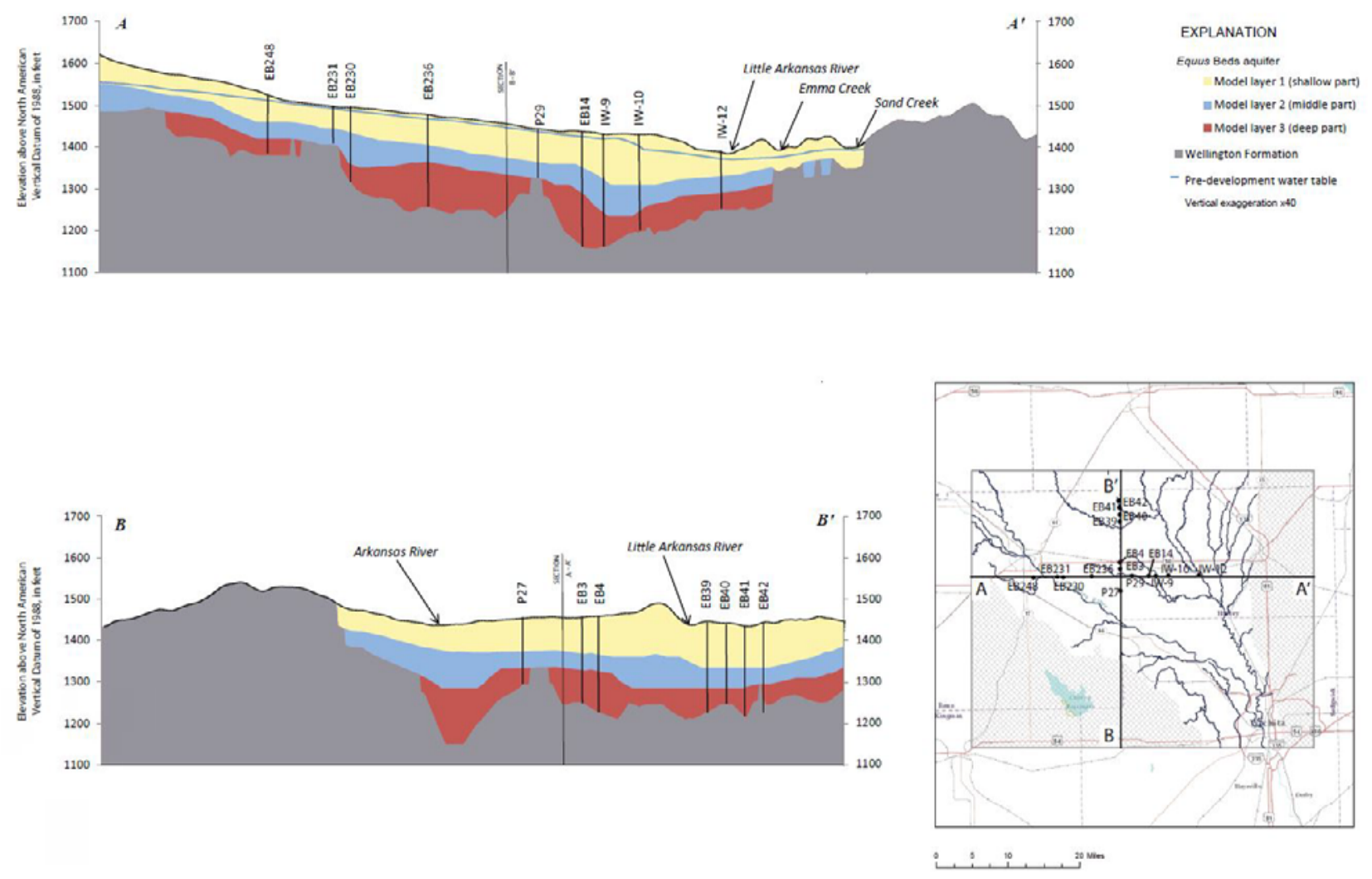

Figure 3. Geologic sections for the Equus Beds aquifer in the study area.

Recharge is variable reflecting differences in soil permeability and varies from 5 percent to about 32 percent of precipitation (Kelly and others, 2013). Assuming 30 in. of rainfall per year (National Oceanic and Atmospheric Administration, 2008), recharge to the aquifer in the study area based on these percentages would range from 1.5 to $10 \mathrm{in}$. per year.

In 2008, 157 municipal production wells, 986 irrigation wells, and 104 industrial wells were in operation in the active-model area (figs. 1 and 4) (Kelly and others, 2013). In the study area, water pumped from the aquifer by production wells in 2008 was about 4,370,000 cubic feet per day $\left(\mathrm{ft}^{3} / \mathrm{d}\right)$, which is about 100 acre-feet per day (acre-ft/d) (Kansas Department of Agriculture - Division of Water Resources, unpub. data, 2009). From 1939 through 2008, total amount of water pumped (cumulative pumping) from the Equus Beds aquifer in the study area was estimated to be almost 273 billion cubic feet $\left(\mathrm{ft}^{3}\right)$ (6.26 million acre-ft). Water withdrawal steadily increased from 1939 to 1991 and then stabilized from 1992 through 2008 to between 12 and 18 million $\mathrm{ft}^{3} / \mathrm{d}$ ( 275 to 413 acre-ft /d). Municipal and industrial withdrawal decreased but irrigation withdrawal increased from 1990 through 2008. Cumulative withdrawal and pumping rate for the Equus Beds aquifer by industrial, irrigation, municipal, artificial-recharge and artificial-withdrawal wells from 1939 through 2008 is shown in figure 5 . 


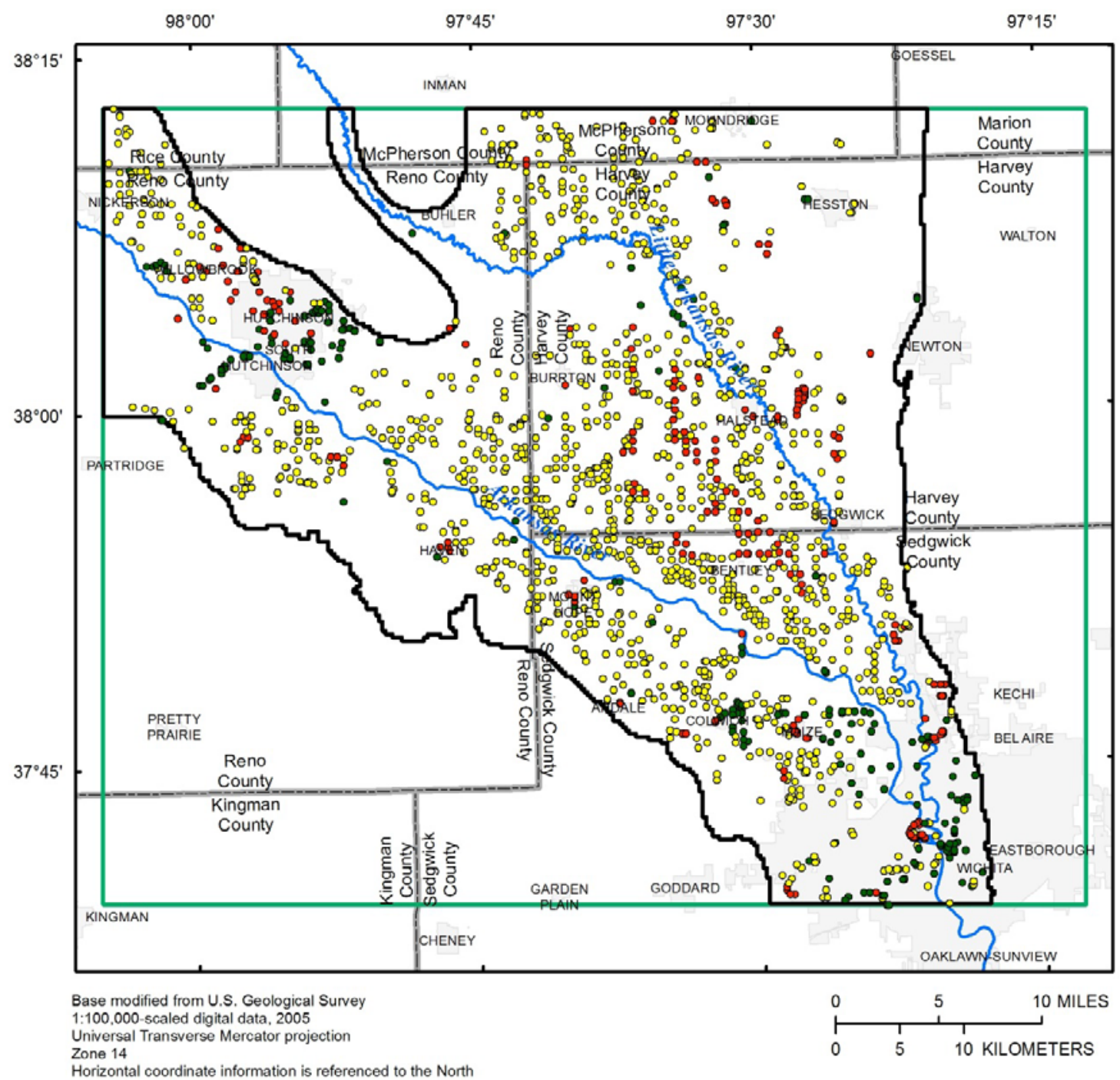

Horizontal coordinate information is referenced to the North

EXPLANATION

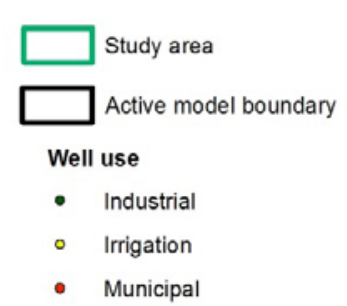

Figure 4. Map showing locations of industrial, irrigation, and municipal wells in the model area. 

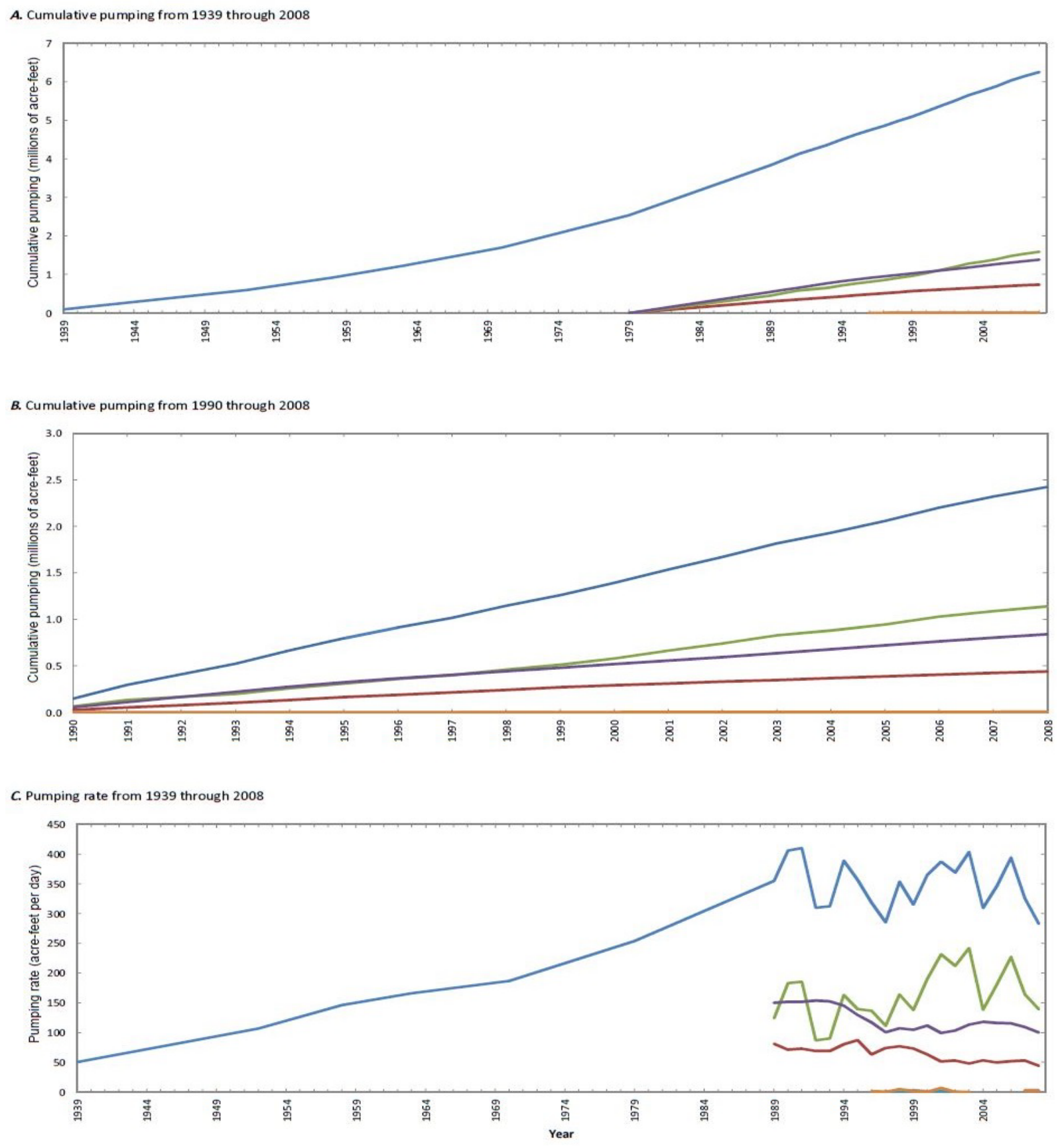

Figure 5. Graphs showing amount of water pumped or recharged from the Equus Beds aquifer by industrial, irrigation, municipal withdrawal, artificial recharge and artificial withdrawal from wells in the study area. (A), 1939 through 2008. (B), 1990 through 2008. (C), cumulative-pumping rate 1939 through 2008. 
Evapotranspiration from the water table removes water from the aquifer when the water table is near land surface and within the root zone of vegetation. Evapotranspiration is a combination of evaporation and uptake of water by plants and is greatest during the growing season. Evapotranspiration was estimated by Spinazola and others (1985) to be 3.5 inches per year. Total estimated evapotranspiration is about 24.7 million $\mathrm{ft}^{3} / \mathrm{d}$ or 568 acre- $\mathrm{ft} / \mathrm{d}$. The maximum rate of evapotranspiration was estimated for each year from 1990 through 2008 using the Hamon equation (Hamon, 1961; Alkaeed and others, 2006).

\section{Groundwater Levels}

Groundwater-level data have been collected periodically from more than 600 wells by the city of Wichita and GMD2 personnel using standard water-level measurement techniques that are similar to USGS methods described in Cunningham and Schalk (2011). Data collection began just before the beginning of city pumpage from the aquifer in 1940. During 2001 and 2002, 38 pairs of wells designed for use by the city to monitor water quality and water levels in the aquifer and any changes that might occur as a result of the ASR project were installed for the city of Wichita (Debra Ary, city of Wichita, written commun., September 25, 2009). These wells are index monitoring wells, and one pair of wells is located in each index cell of the BSA (fig. 2).

The drought during the 1950s and groundwater pumpage from the aquifer near the WWF for municipal and agricultural use between 1940 and 1957 caused a substantial water-level decline near the WWF (Hansen and Aucott, 2003). Increased irrigation pumpage during the 1970s and 1980s caused further declines in groundwater levels (Myers and others, 1996; Aucott and Myers, 1998). Most of the water-level declines were caused by groundwater pumpage but the effects of climate on recharge also have affected water levels (Hansen and Aucott, 2003). However, groundwater levels in parts of the aquifer near the WWF (fig. 1) increased by more than $20 \mathrm{ft}$ between 1992 and 2006 because of subsurface inflow, streamflow losses, and irrigation return flow (Kelly and others, 2013).

\section{Groundwater-Flow and Chloride-Transport Directions in the Equus Beds Aquifer}

Groundwater generally flows from west to east between the Arkansas and Little Arkansas River and flows from north to south in the area north of the Little Arkansas River. Groundwater withdrawals create localized cones of depression around each well or well field that may alter regional groundwaterflow direction and cause groundwater to flow toward the wells. The groundwater-flow direction along most of the Arkansas River in the study area is to the southeast, generally parallel to the river. Near the WWF, the flow direction is more eastward, and has a northward component of flow in some areas, most likely because of water-level declines caused by pumping in the WWF (Hansen and Aucott, 2003). The direction of groundwater flow in and near the Burrton plume is to the southeast, toward the WWF.

The west to east flow of groundwater between the Arkansas and Little Arkansas Rivers causes chloride (that has infiltrated from the Arkansas River) to move toward the well field. This movement combined with withdrawal from the Wichita well field and from nearby irrigation wells, has increased the hydraulic gradient toward the well field from surrounding areas.

The oil-field brines that were disposed of near Burrton have moved downward into the middle part of the aquifer, but movement into the deep part has been slower because of clay layers. Chloride concentrations in the shallow part of the aquifer are diluted by recharge (precipitation), whereas in the deep part of the aquifer, chloride has moved laterally and downward because of the density contrast between the chloride and fresher waters (Whittemore, 2007).

Some other possible factors affecting chloride transport in the model area include evapoconcentration, upwelling of saline water from the underlying Wellington Formation, and 
continued leaching of oil-field brine from the vadose zone. Evapoconcentration occurs when water is removed from the aquifer through evapotranspiration; chloride remains and leaves a more concentrated solution. The existence of upwelling of saline water from the Wellington Formation has been well documented (Walters, 1978), but the locations and loading rates have not been well defined. Brine in the Burrton oil-field may still be in the unsaturated zone, and can percolate and infiltrate into the aquifer with recharge, but data and information about this type of transport are scarce.

\section{Methods Used to Simulate Groundwater Flow and Chloride Transport}

A detailed description of the groundwater-flow model is presented in Kelly and others (2013) and is summarized below. For this report, the computer software and the equations used to simulate chloride transport are presented and deviations from the groundwater-model input required for chloridetransport simulation are discussed including deviations in the temporal discretization, initial-head distribution, the format for the well pumping input file, and use of effective porosity (the fraction of a volume of aquifer material that is composed of interconnected pore space and thus is available for fluid flow). Chloride sources and sinks are described and the techniques and data used to determine the initial distribution of chloride concentration are presented; locations of observed chloride concentrations are shown and analysis of chloride transport output and model limitations are discussed.

\section{Description of the Groundwater-Flow Model}

Groundwater flow was simulated for the Equus Beds aquifer using the three-dimensional finitedifference groundwater-flow model MODFLOW (McDonald and Harbaugh, 1988; Harbaugh and others, 2000; and Harbaugh, 2005). The primary areas of interest include the Equus Beds aquifer near the city of Wichita supply wells and the areas around existing ASR Phase 1 and 2 artificial-recharge areas (fig 2).

The groundwater-flow model simulates steady-state and transient conditions. For steady-state conditions, the model uses average hydrologic conditions from 1935 through 1939, and for transient conditions the model uses hydrologic conditions from 1935 through 2008. Hydrologic processes that were simulated in Kelly and others (2013) included recharge, evapotranspiration, streamflow gains and losses, flow into and out of lateral boundaries, and well pumping.

The model accuracy (Kelly and others, 2013) was estimated using several methods. The root mean square (RMS) error between observed and simulated hydraulic head as well as observed and simulated streamflow gains or losses were calculated for each well and stream observation for the entire transient simulation. Model accuracy was increased by minimizing the RMS error during the calibration process. The RMS error measures the absolute value of the variation between observed and simulated hydraulic heads at control points or the variation between observed and simulated streamflow along stream reaches. The equation to calculate the RMS error is:

$$
\text { RMS error }=\sqrt{\frac{e_{1}^{2}+e_{2}^{2}+e_{3}^{2}+\ldots e_{n}^{2}}{n}}
$$

where $\quad e \quad$ is the difference between the observed and simulated values; and $n$ is the number of observations.

The groundwater-flow model was calibrated by adjusting model-input data and model-geometry data until model results matched field observations within an acceptable level of accuracy. The RMS 
error for all water-level observations for the steady-state calibration simulation was $9.82 \mathrm{ft}$. The ratio of the RMS error to the total-head loss in the model area was 4.9 percent. The mean error (observed minus simulated water levels) for 284 water-level observations was $3.86 \mathrm{ft}$. The difference between groundwater flow into and out of the model across all model boundaries (the volumetric budget) was 0.08 percent of total flow for the steady-state calibration.

The RMS error for all water-level observations for the transient calibration simulation was 2.48 $\mathrm{ft}$. The ratio of the RMS error to the total head loss in the model area was 1.24 percent. The mean error for all water-level observation wells used in the transient calibration simulation is $0.03 \mathrm{ft}$. Simulated water levels are similar to the observed long-term trends for all wells, which indicates adequate simulation of long-term changes to groundwater levels resulting from sustained stresses on the aquifer, such as overall rate of groundwater withdrawal, gains from and losses to streams, or long-term trends in recharge.

The RMS error calculated for observed and simulated gains or losses in base flow for the Arkansas River for the transient simulation was 7,916,564 $\mathrm{ft}^{3} / \mathrm{d}\left(91.6 \mathrm{ft}^{3} / \mathrm{s}\right)$ and the RMS error divided by the total range in streamflow was 22 percent. The RMS error calculated for observed and simulated streamflow gains or losses for the Little Arkansas River for the transient simulation was 5,610,089 $\mathrm{ft}^{3} / \mathrm{d}$ $\left(64.9 \mathrm{ft}^{3} / \mathrm{s}\right)$ and the RMS error divided by the total range in streamflow was 13 percent. The mean error between observed and simulated gains or losses in base flow was $29,999 \mathrm{ft}^{3} / \mathrm{d}\left(0.34 \mathrm{ft}^{3} / \mathrm{s}\right)$ for the Arkansas River and $-1,369,250 \mathrm{ft}^{3} / \mathrm{d}\left(-15.8 \mathrm{ft}^{3} / \mathrm{s}\right)$ for the Little Arkansas River. Cumulative streamflow gain and loss observations are similar to the cumulative simulated equivalents. Average percent massbalance difference for individual stress periods ranged from -0.46 to 0.51 percent. The cumulative-mass balance for the transient calibration was 0.01 percent.

For the groundwater-flow model (Kelly and others, 2013), the simulated hydraulic conductivity ranged from 0.25 to $1,200 \mathrm{ft} /$ day in model layer 1 ; from 5 to $600 \mathrm{ft} /$ day in model layer 2; and from 10 to $800 \mathrm{ft} /$ day in model layer 3 (fig. 3). A specific yield of 0.15 and a specific storage of 0.0005 were used for all model layers. Simulated recharge in the groundwater-flow model ranges from 5 to 32 percent of precipitation. Evapotranspiration was set to the maximum rate when the water table is at land surface and was set to zero when the depth to the water table was more than the extinction depth (depth below land surface at which evapotranspiration from the water table ceases to occur), which was assumed to be $10 \mathrm{ft}$ below land surface. The extent of the active-model area and thickness of each model layer are shown in figures 6, 7, and 8. All model layers were treated as convertible between confined and unconfined.

Kelly and others (2013) performed a sensitivity analysis to determine the magnitude of the response of simulated heads and flows when changes were made to various input parameters. Composite scaled sensitivities were calculated for the steady-state and transient calibration simulations and one-percent sensitivities were calculated for the transient calibration simulation. Larger responses in model output to parameter changes indicate the model is more sensitive to the parameter. Parameters with the largest sensitivities were those with large areal distributions, such as evapotranspiration, recharge zones, and horizontal hydraulic conductivity zones. Parameters with relatively low sensitivities were storage terms, vertical hydraulic conductivity, and small recharge and horizontal hydraulic conductivity zones. A detailed description of the sensitivity analysis can be found in the groundwaterflow model documentation (Kelly and others, 2013). 


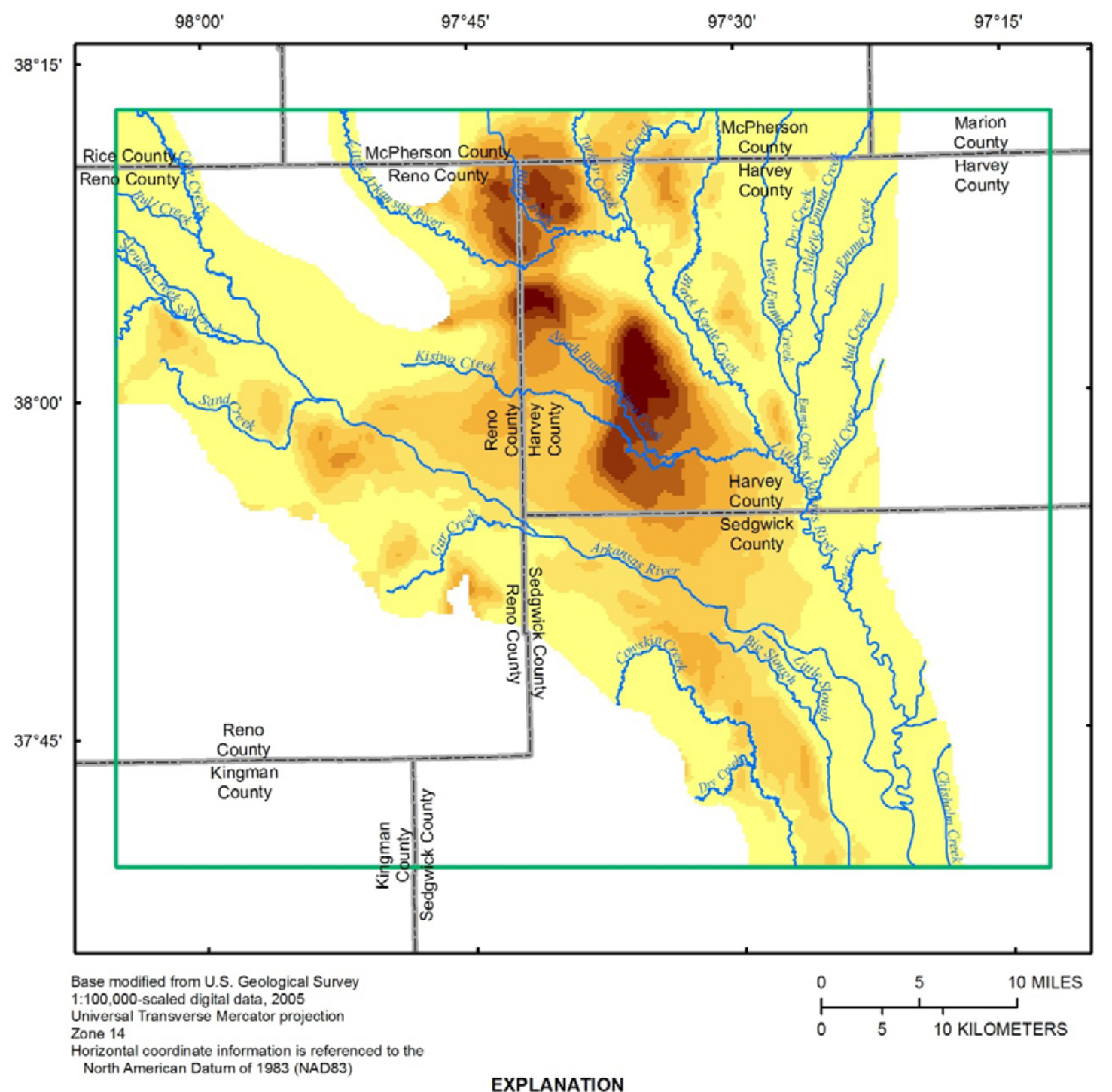

Model layer 1

Thickness in feet

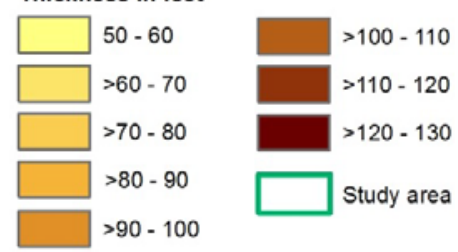

Figure 6. Map showing thickness of active-model area of model layer 1 


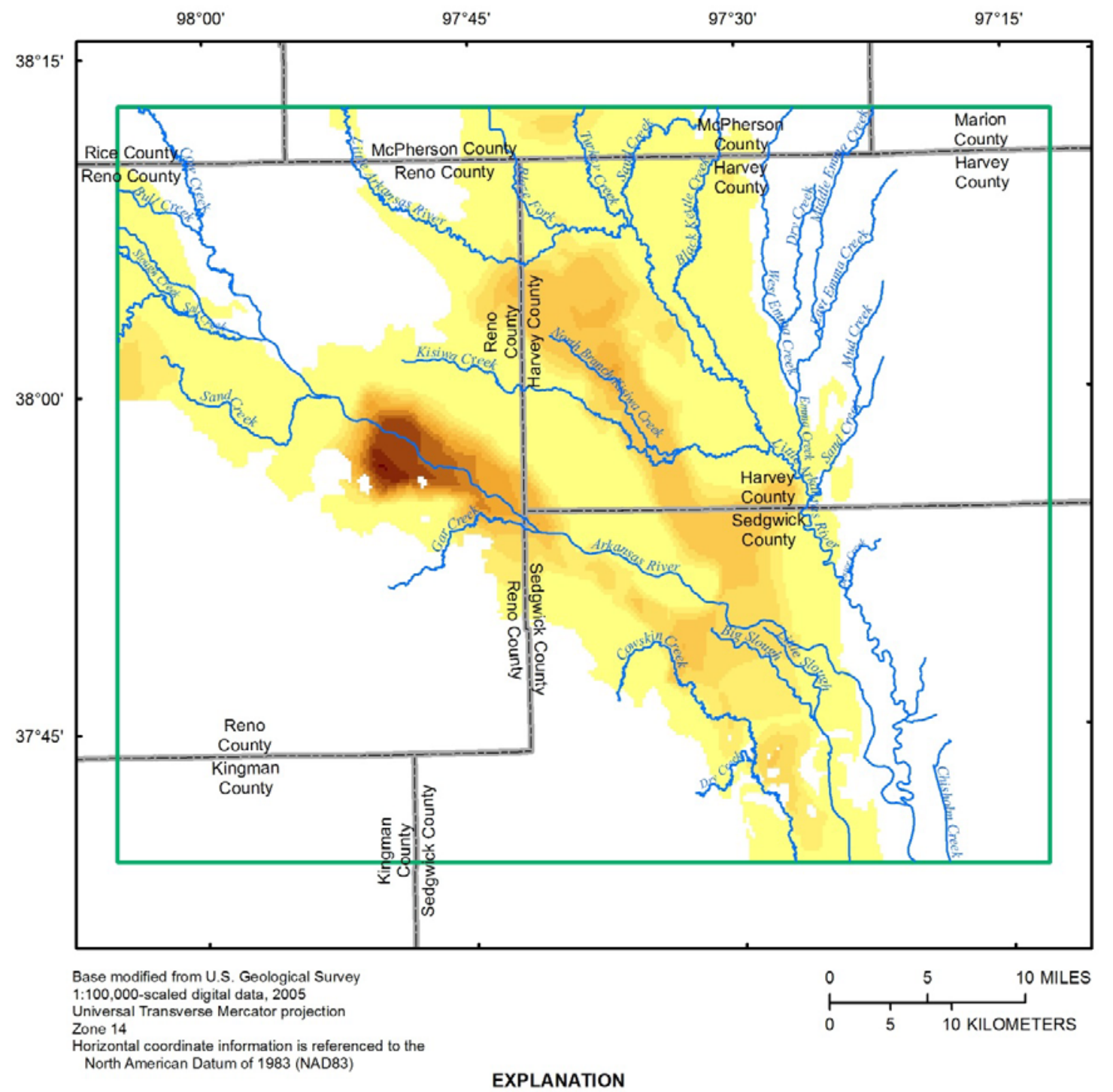

Model layer 2

Thickness in feet

$\begin{array}{llll}\square & 40-50 & & >100-110 \\ \square & >50-60 & & >110-120 \\ \square & >60-70 & & >120-130 \\ \square & >70-80 & >130-140 \\ \square & >80-90 & >140-150 \\ \square & >90-100 & & \\ \square & \text { Study area }\end{array}$

Figure 7. Map showing thickness of active-model area of model layer 2 


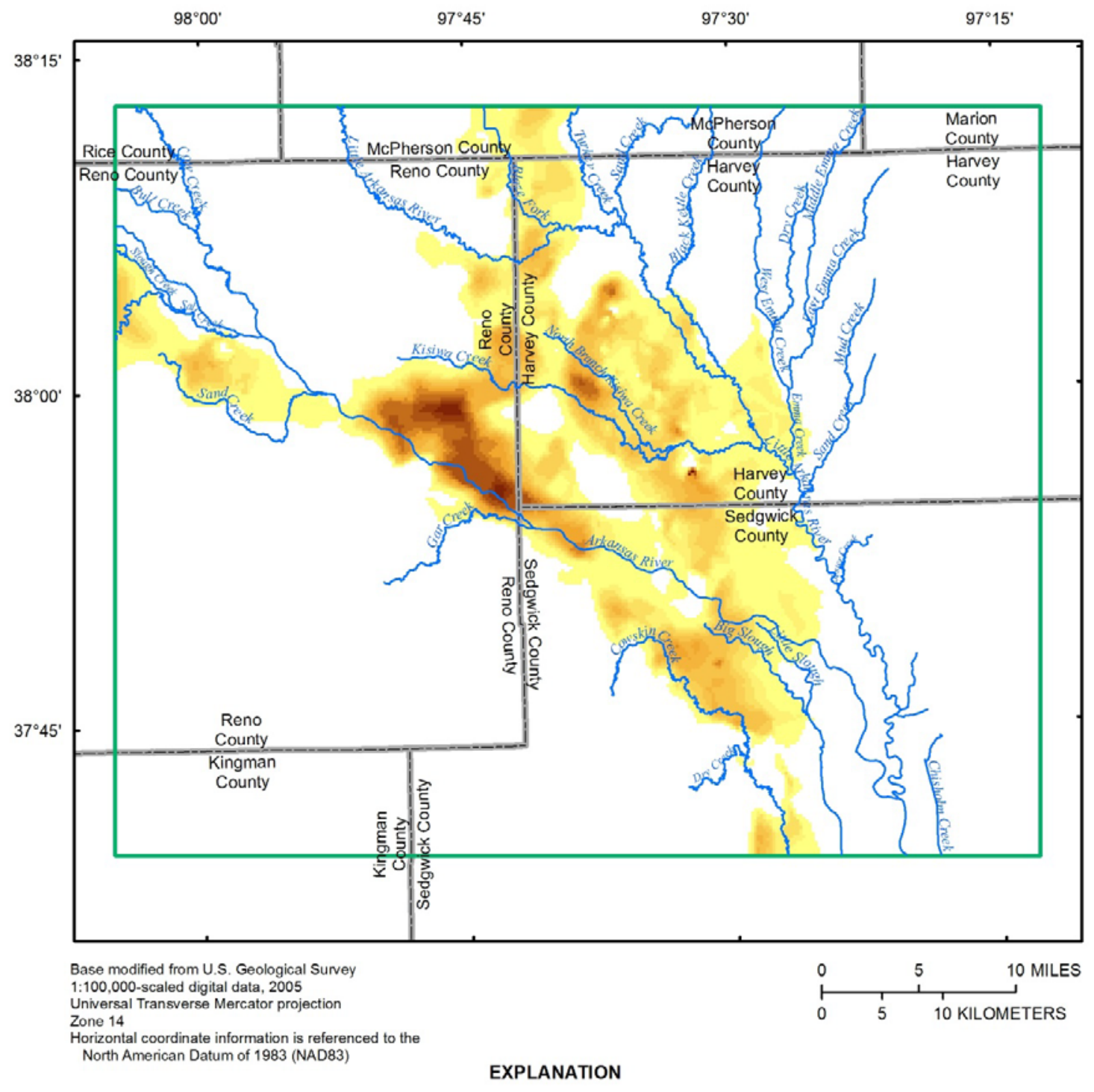

Model layer 3

Thickness in feet

\begin{tabular}{|c|c|}
\hline $40-50$ & $>110-120$ \\
\hline$>50-60$ & $>120-130$ \\
\hline$>60-70$ & $>130-140$ \\
\hline$>70-80$ & $>140-150$ \\
\hline$>80-90$ & $>150-160$ \\
\hline$>90-100$ & $>160-170$ \\
\hline$>100-110$ & Study area \\
\hline
\end{tabular}

Figure 8. Map showing thickness of active-model area of model layer 3 


\section{Description of Chloride-Transport Model}

Chloride transport was simulated using SEAWAT Version 4 (Langevin and others, 2008), a computer program that combines the three-dimensional finite-difference groundwater-flow model MODFLOW-2000 (Harbaugh and others, 2000) and a three-dimensional multi-species transport model called MT3DMS (Zheng and Wang, 1999) for simulation of advection, dispersion, and chemical reactions of contaminants in groundwater. SEAWAT uses a combination of input files from MODFLOW and MT3DMS, with minor modifications to some of the input files.

SEAWAT calculates hydraulic heads differently than MODFLOW because the program takes into account the variation of fluid density and viscosity that result from changes in solute concentration, temperature, and pressure. However, MODFLOW calculates hydraulic head based on the constantdensity of groundwater. Whittemore (2012) attributes the downward migration of brine in the Burrton area to density differences between the oil-field brine and the fresh water of the aquifer. The equation used for the variable-density groundwater flow process in SEAWAT Version 4 is:

$$
\nabla \cdot\left[\rho \frac{\mu_{0}}{\mu} \mathrm{K}_{0}\left(\nabla h_{0}+\frac{\rho-\rho_{0}}{\rho_{0}} \nabla z\right)\right]=\rho S_{s, 0} \frac{\partial h_{0}}{\partial t}+\theta \frac{\partial \rho}{\partial C} \frac{\partial C}{\partial t}-\rho_{s} q_{s}
$$

where $\quad \nabla \quad$ is the gradient operator;

$\rho$ is the fluid density, in pounds per cubic foot;

$\rho_{0}$ is the density of fresh water, in pounds per cubic foot;

$\mu$ is the fluid viscosity, in pounds per foot per day;

$\mu_{0}$ is the viscosity of fresh water, in pounds per foot per day;

$\mathrm{K}_{0}$ is the hydraulic conductivity tensor of the saturated aquifer material, in feet per

day;

$h_{0}$ is the hydraulic head, in feet;

$z$ is the upward coordinate direction;

$S_{s}$ is the specific storage, in feet-1;

$t$ is time, in days;

$\theta$ is the porosity of the aquifer material, dimensionless;

$C$ is the solute concentration, in pounds per cubic foot;

$q_{s} \quad$ is the specific discharge of a source or sink of fluid, in days-1, of fluid with density $\rho_{s}$, in pounds per cubic foot.

SEAWAT uses the following solute-transport equation:

$$
\frac{\partial C}{\partial t}=\nabla \cdot(D \cdot \nabla C)-\nabla \cdot(\vec{v} C)-\frac{q_{s}}{\theta} C_{S}
$$

where $D \quad$ is the hydrodynamic dispersion coefficient, in square feet per day;

$\vec{v}$ is the fluid velocity, in feet per day;

$C_{s}$ is the solute concentration of water entering from sources or sinks, in pounds per cubic foot, and where all other terms are previously defined.

The advective transport of contaminants at the same velocity as the groundwater flow is often the dominant mechanism in solute transport (Zheng and Wang, 1999) and is represented by the velocity term $(\vec{v})$ in the solute-transport equation (equation 3). Advection causes aquifer properties, such as hydraulic conductivity and effective porosity, to have a high degree of influence over solute transport because these properties control groundwater-flow velocity. 
Hydrodynamic dispersion is the lateral and vertical mixing of a contaminant plume to a larger volume of water within the aquifer than what is typically affected by average groundwater flow. This dispersion term is defined as the sum of the mechanical dispersion and diffusion and acts on a microscopic scale by the deviations of the actual groundwater velocity from the average velocity, and also by molecular diffusion because of concentration gradients (Zheng and Wang, 1999). On a macroscopic scale, hydrodynamic dispersion can be caused by lithological heterogeneities. Simulating dispersion as zero produced the best model fit and also forced the advective transport to dominate the system and indicate areas where the simulated groundwater-flow velocities $(\vec{v})$ may not be realistic. Simulated chloride concentrations that change more quickly at a well location than the observed chloride concentrations might indicate that groundwater-flow velocities toward the well location are too high, whereas simulated chloride concentrations that change more slowly than observed chloride concentrations might indicate that the groundwater-flow velocities toward the location are too low. Although the dispersion was set to zero in the model input, some dispersion was simulated due to numerical dispersion, which is caused by truncation error (introduced by approximating the continuous solution of a differential equation in a finite number of steps) (Zheng and Wang, 1999).

\section{Modifications to Groundwater-Flow Model for Use with the Chloride-Transport Model}

The chloride-transport model documented in this report supplements the groundwater-flow model developed by Kelly and others (2013). To preserve their calibration of the model, changes to input data to the groundwater-flow-model were kept to a minimum. Some minor changes were necessary to accommodate the chloride-transport simulation, but these changes did not change the flow model solution.

The temporal discretization of the chloride-transport model included fewer stress periods, with more time steps per stress period than the groundwater-flow model developed by Kelly and others (2013). The chloride-transport model simulates the period from 1990 through 2008 with 19 stress periods with each stress period equal to 365 or 366 days; each stress period was then divided into 300 time steps. The initial stress period of the groundwater-flow model begins in 1935 and has 26 stress periods with 50 time steps. Because of the difference in initial time between the two models, a different set of initial heads were used in the chloride-transport model. Thus, heads from the groundwater-flow model output at the end of 1989 (Kelly and others, 2013) were used for the initial heads for the chloridetransport model.

The groundwater-flow model (Kelly and others, 2013) used the multi-node well (MNW2) package of MODFLOW (Konikow and others, 2009) to simulate well pumping in the model area. This package is not compatible with SEAWAT. The MNW2 used in the flow model was converted into a format compatible with SEAWAT, which was MODFLOW's original multi-node well (MNW1) package (Halford and Hanson, 2002). The MNW1 package that was used for the chloride-transport simulations contains the same pumping rates as the MNW2 package used in the flow model; thus, the change of format does not impact the flow solution. The MNW1 package does not simulate density effects in SEAWAT.

SEAWAT requires input of the effective porosity for use in the solute transport calculations. This parameter is only used for the solute-transport step and does not affect the groundwater-flow solution. A uniform value of 0.15 was used for the effective porosity, which is consistent with the value of 0.15 used for specific yield in the Kelly and others (2013) groundwater-flow model. 


\section{Chloride Sources and Sinks}

The chloride-transport model could simulate chloride so that it was either added or subtracted from the model area (sources and sinks). These sources and sinks included transport of chloride with groundwater as it flowed across the boundaries of the model area, natural and artificial recharge, well pumping, and interaction with surface water.

Places where the active-model cells were adjacent to the active-model boundary, known as head-dependent boundaries, were assigned a constant chloride concentration of $20 \mathrm{mg} / \mathrm{L}$, which was a value assumed to be representative of background chloride concentrations in groundwater based on chloride concentrations from samples upgradient of the study area (U.S. Geological Survey, 2014b). Head-dependent boundaries could act as sources or sinks for chloride, depending on the relative heads of the boundary and the adjacent active-model cell. Head difference between the boundary and a model cell created a hydraulic gradient across the boundary. The groundwater flow through the boundary was a function of the hydraulic gradient and the transmissivity of the aquifer. Kelly and others (2013) assigned water-table (unconfined conditions) values located 20 miles (mi) outside of the model area for the constant-head values at the boundary. The bottom of the model layer 3 (figs. 3 and 8) was modeled as a no-flow boundary, which prevented the simulation of upward flow of high-chloride water from the underlying Wellington Formation.

Sources of chloride from recharge primarily were from precipitation and artificial recharge. First, the chloride concentration of recharge to the aquifer from precipitation was assumed to be 0.2 $\mathrm{mg} / \mathrm{L}$, which was based on nationwide data about rainwater composition compiled by Root and others (2004). Second, artificial recharge entering the aquifer through recharge basins or injection wells was another source of chloride to the aquifer. Chloride concentrations input into the chloride-transport model for the artificially recharged water were calculated by using values from samples of treated recharge water.

Possible sinks for chloride included evapotranspiration and pumping. The chloride concentration of water removed from the model area by evapotranspiration was assumed to be zero because evapotranspiration is thought to remove only pure water and not solutes (chloride) from the aquifer (Zheng and Wang, 1999). Pumping wells that removed water from the aquifer were considered chloride sinks. In reality, chloride pumped through irrigation wells would return to the aquifer in a more concentrated return flow, but in these simulations irrigation-return flow was accounted for by reducing the pumping rates of the irrigation wells (Kelly and others, 2013).

Additionally, surface water in the model area can act as a chloride source or sink to groundwater depending on whether the river was losing water to or gaining water from the aquifer in a given stress period. Data from surface-water samples collected by the USGS and KDHE at sites within the study area from 1990 through 2008 were used to interpolate chloride concentrations for each river reach in each stress period (U.S. Geological Survey, 2014b; Kansas Department of Health and Environment, written commun., 2009). Stage values from streamflow-gaging stations along the Arkansas River, Cow Creek, and the Little Arkansas River were used to calculate average stage values for the gage locations in each stress period and interpolate stage values for river cells between gages (Kelly and others, 2013). Other streams in the model area were simulated as drains, meaning that they could only gain water from the aquifer, and therefore act only as chloride sinks.

For this chloride-transport simulation, brine from the Burrton oil field was assumed to have completely infiltrated and percolated through the unsaturated zone and entered the saturated zone. Chloride from the Burrton plume was assumed to have entered the aquifer very quickly and was not greatly diluted because of sandy surface deposits and shallow depth to water (Burrton Task Force, 1984). 


\section{Chloride Concentrations in Groundwater used for the Initial Conditions in the Chloride-Transport Model}

An initial chloride concentration for each active model cell was input into the simulation. These concentrations represent the conditions in the Equus Beds aquifer at the beginning of 1990. Values at well locations were first estimated using data from available samples collected in 1989 and 1990. To achieve an adequate density of points to interpolate areas between well locations, data from samples collected from 1985 to 1988 were also used when samples were not available from 1989 or 1990. If two or more wells with chloride values in the same year were located in the same cell, the average of their initial values was used for that cell. A geographic information system (GIS) was used to interpolate values of initial concentrations for cells between well locations, using the natural neighbor interpolation method (Sibson, 1981). The interpolated chloride distribution was modified to improve the fit of simulated chloride concentrations with the chloride concentrations from sampled wells. Only interpolated values were modified; the values at sample locations were left unchanged. The initial chloride distributions for each model layer are presented in figures 9, 10, and 11.

\section{Observed Chloride Concentrations}

Chloride-concentration data from groundwater samples taken during the study period in the model area was needed for comparison with simulated chloride concentrations output by the model. Chloride-concentration data was obtained from the USGS and GMD2 for 4,498 groundwater samples collected from 503 wells in the model area from 1990 through 2008 (figs. 12, 13, and 14) (U.S. Geological Survey, 2014b; Equus Beds Groundwater Management District No. 2, written commun., 2009). Chloride concentrations from these samples were compared with simulated values from the same year (stress period) as the sample and from the model cell where the well was located. The altitudes of the tops and bottoms of the screened intervals of sampled wells were compared to the altitudes of the tops and bottoms of the model cells to determine if groundwater samples were from layers 1,2 , or 3 . Of the 4,498 samples, 2,082 of the samples were determined to be from model layer 1, 1,206 samples were determined to be from model layer 2, and 1,210 samples were determined to be from model layer 3 (table 1). If more than one sample was available from a cell during a stress period, the observed chloride concentrations were averaged to estimate a single chloride concentration value (observed value) for comparison with the cell's simulated value. 


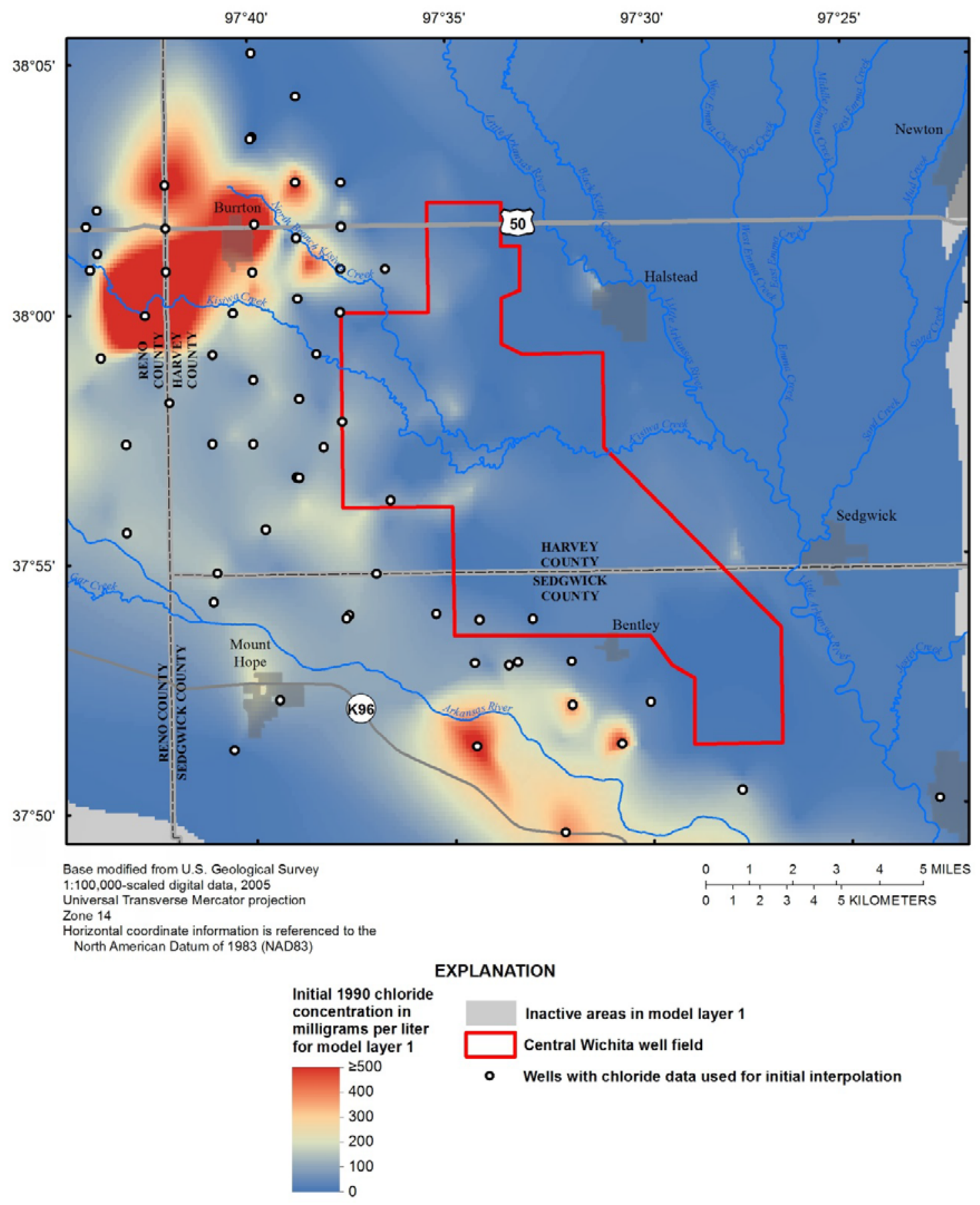

Figure 9. Map showing initial (1990) chloride distribution in and around the Wichita well field for model layer 1 


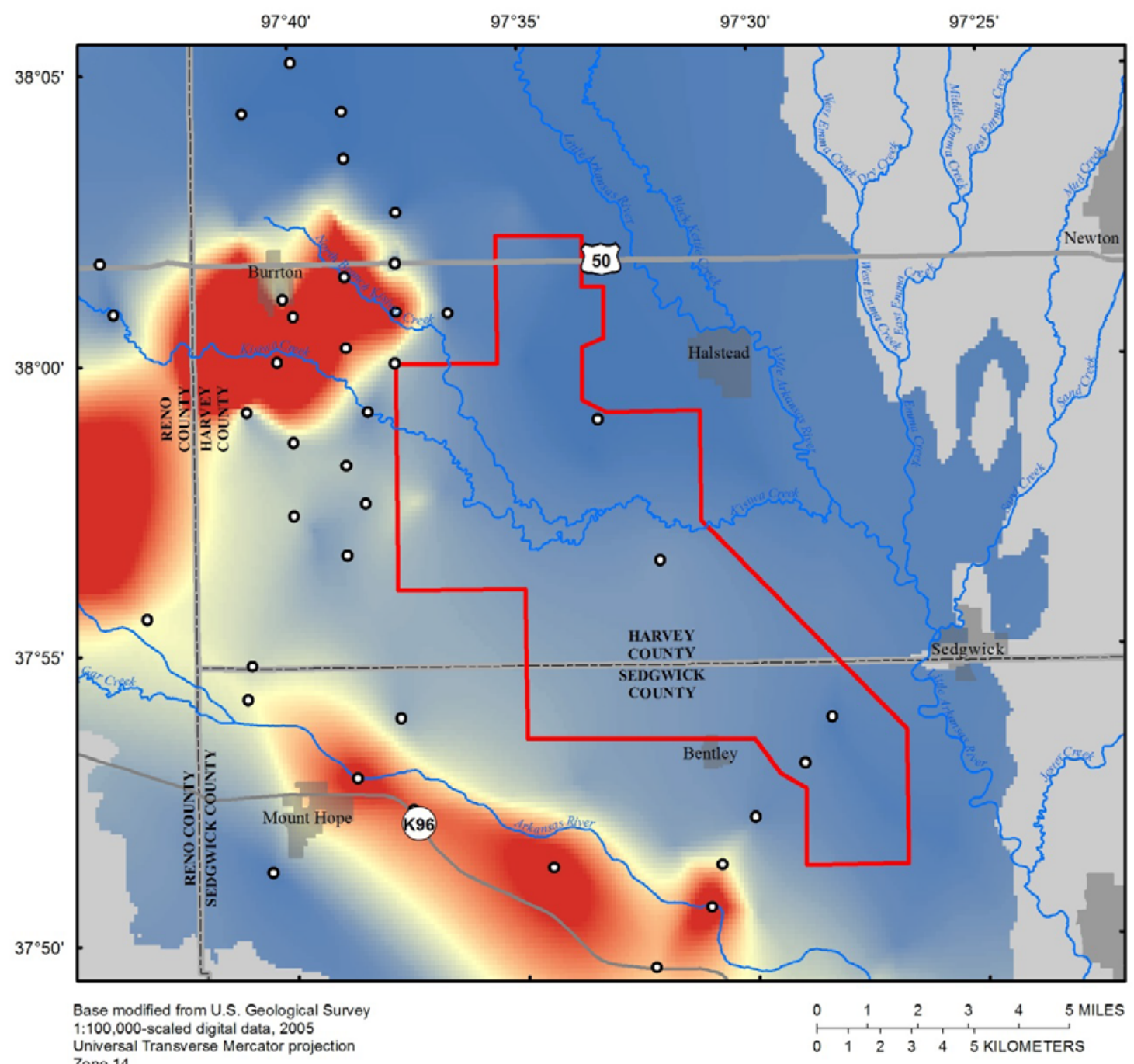

Universal Transverse Mercator projection

Zone 14

Horizontal coordinate information is referenced to the

North American Datum of 1983 (NAD83)

EXPLANATION

Initial 1990 chloride

concentration in

milligrams per liter

for model layer 2

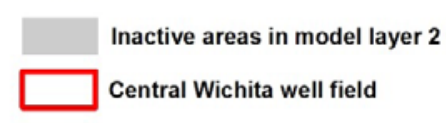

$\geq 500$

- Wells with chloride data used for initial interpolation

400

$-300$

200

$-100$

0

Figure 10. Map showing initial (1990) chloride distribution in and around the Wichita well field for model layer 2 


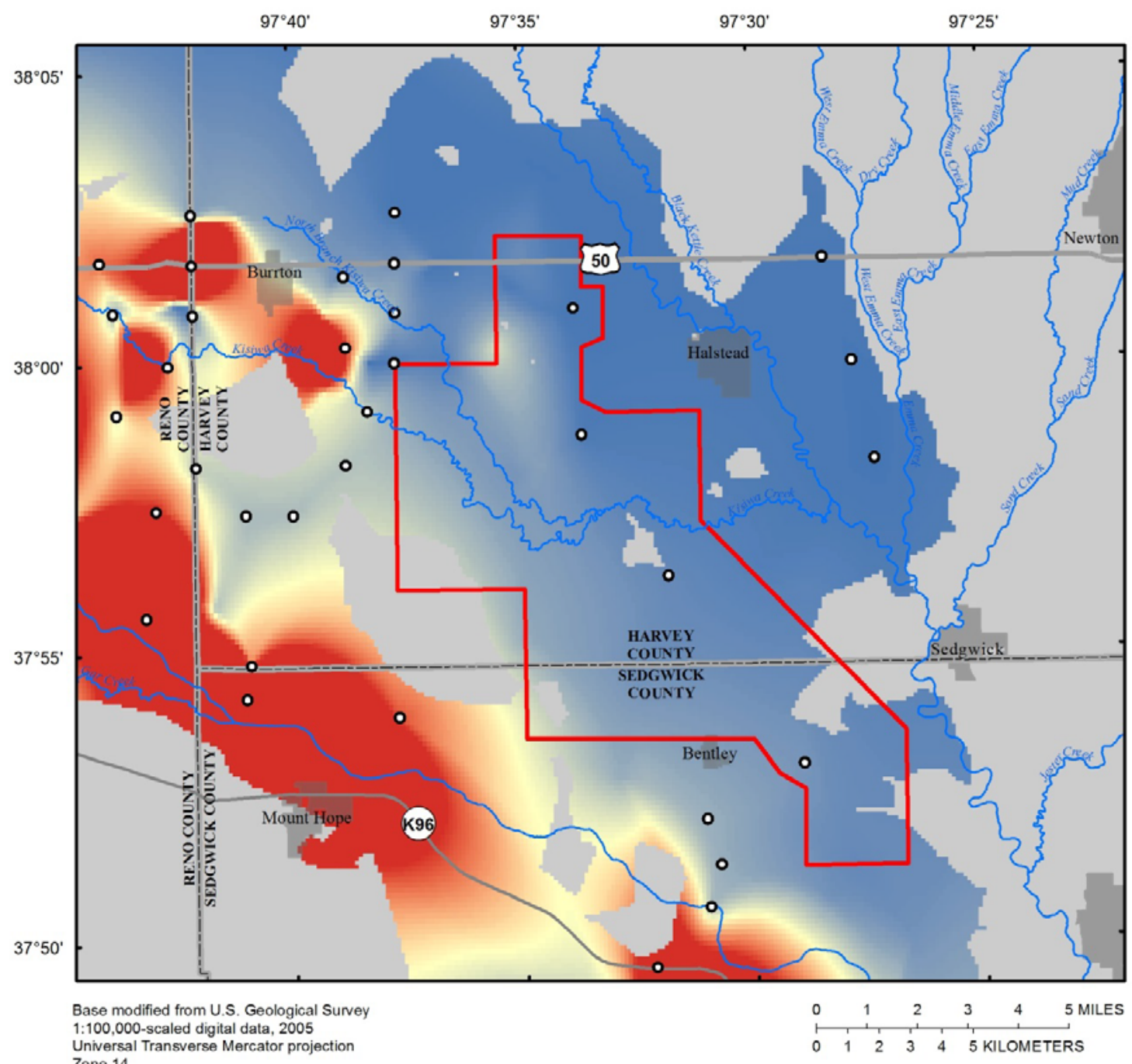

Universal Transverse Mercator projection

Zone 14

Horizontal coordinate information is referenced to the North American Datum of 1983 (NAD83)

EXPLANATION

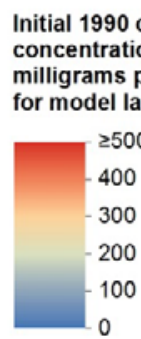

Figure 11. Map showing initial (1990) chloride distribution in and around the Wichita well field for model layer 3 
Table 1. Number of chloride samples analyzed per model layer in each stress period.

\begin{tabular}{cccccc}
\hline \multirow{2}{*}{$\begin{array}{c}\text { Stress } \\
\text { period }\end{array}$} & Year & $\begin{array}{c}\text { Model Layer } \\
\mathbf{1}\end{array}$ & $\begin{array}{c}\text { Model Layer } \\
\mathbf{2}\end{array}$ & $\begin{array}{c}\text { Model Layer } \\
\mathbf{3}\end{array}$ & Total \\
\cline { 3 - 6 } & & \multicolumn{4}{c}{ Number of chloride samples } \\
\hline 1 & 1990 & 107 & 76 & 65 & 248 \\
3 & 1991 & 105 & 77 & 66 & 248 \\
4 & 1992 & 63 & 35 & 40 & 138 \\
5 & 1993 & 107 & 75 & 65 & 247 \\
6 & 1994 & 66 & 35 & 41 & 142 \\
7 & 1995 & 73 & 41 & 44 & 158 \\
8 & 1996 & 82 & 38 & 42 & 162 \\
9 & 1997 & 108 & 54 & 51 & 213 \\
10 & 1998 & 99 & 55 & 53 & 207 \\
11 & 1999 & 78 & 42 & 47 & 167 \\
12 & 2000 & 103 & 50 & 49 & 202 \\
13 & 2001 & 156 & 101 & 85 & 342 \\
14 & 2002 & 123 & 65 & 69 & 257 \\
15 & 2003 & 126 & 65 & 69 & 260 \\
16 & 2004 & 119 & 65 & 72 & 256 \\
17 & 2005 & 119 & 66 & 71 & 256 \\
18 & 2006 & 196 & 120 & 115 & 431 \\
19 & 2007 & 128 & 74 & 83 & 285 \\
\hline & 2008 & 124 & 72 & 83 & 279 \\
\hline Total & & 2,082 & 1,206 & 1,210 & 4,498 \\
\hline
\end{tabular}

*A stress period represents a length of time in the model where stresses (such as recharge, pumping, or evapotranspiration) are constant. Stresses can only change at the beginning of a new stress period. 


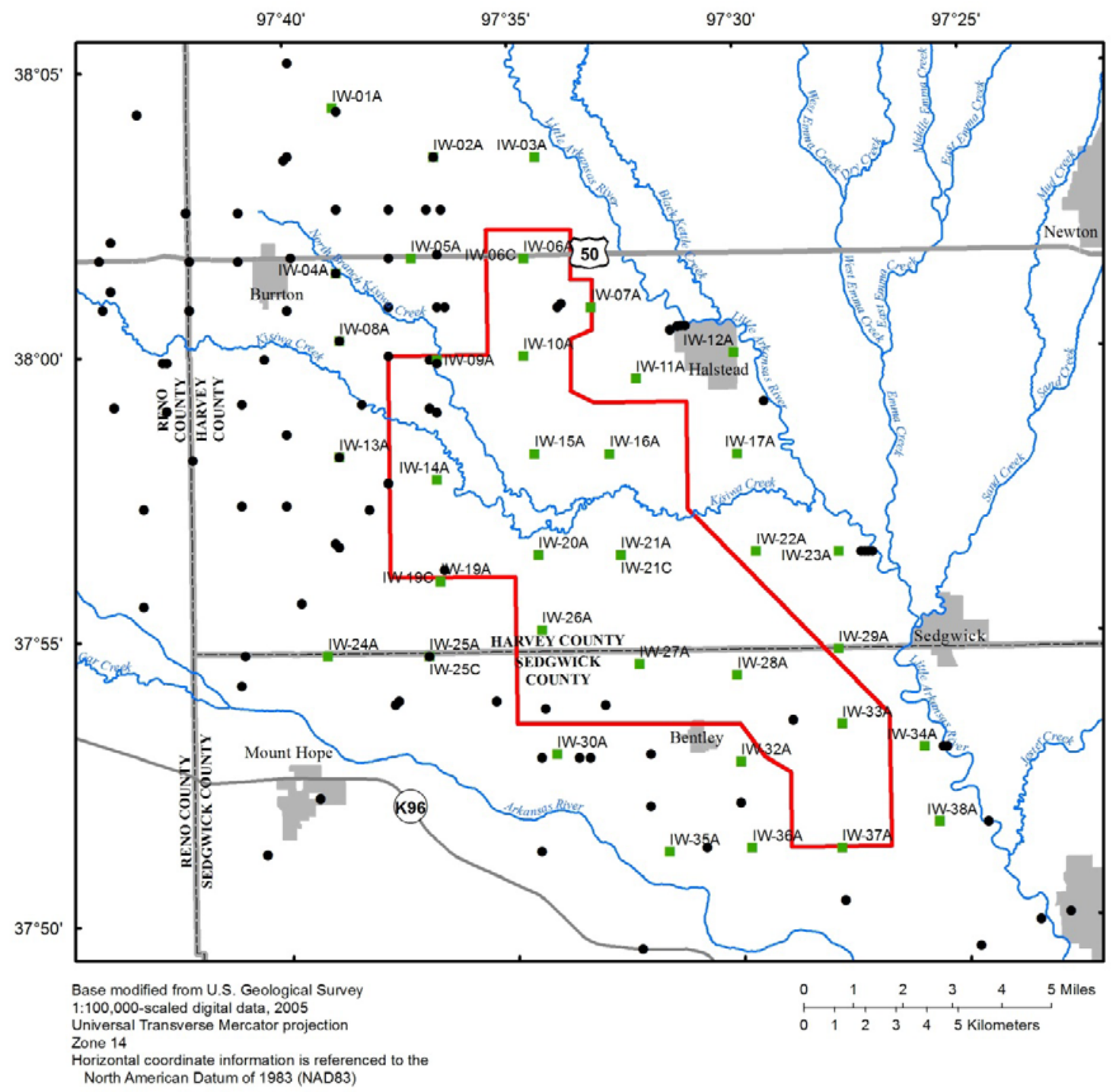

EXPLANATION

Central Wichita well field

Monitoring wells with chloride-concentration data collected during the study period from model layer 1

- Index monitoring wells

- Other monitoring wells

Figure 12. Map showing locations of wells with chloride-concentration data in the study area, model layer 1, 19902008. 


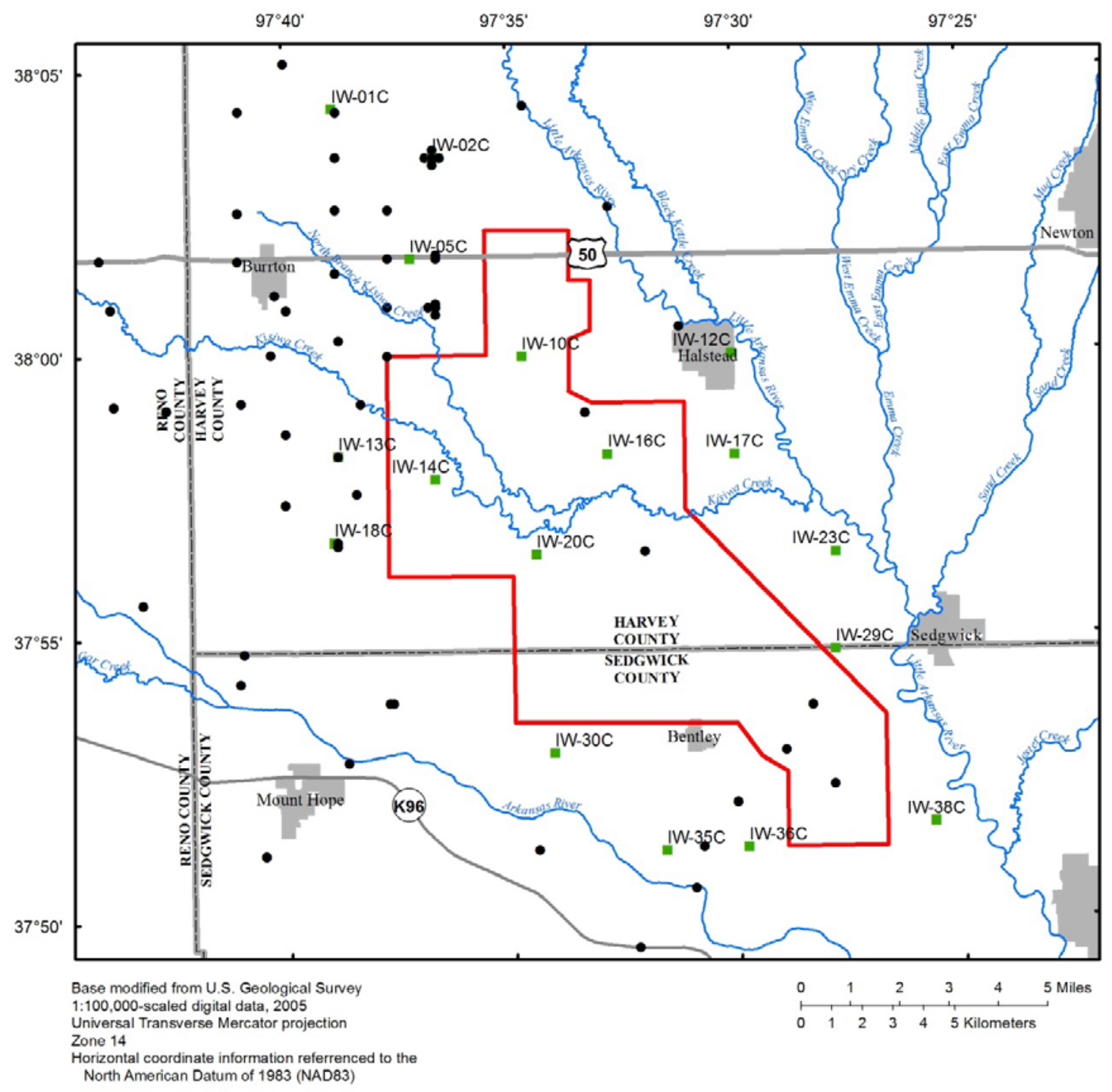

EXPLANATION

Central Wichita well field

Monitoring wells with chloride concentration data collected during the study period from model layer 2

- Index monitoring wells

- $\quad$ Other monitoring wells

Figure 13. Map showing locations of wells with chloride-concentration data in the study area, model layer 2, 19902008. 


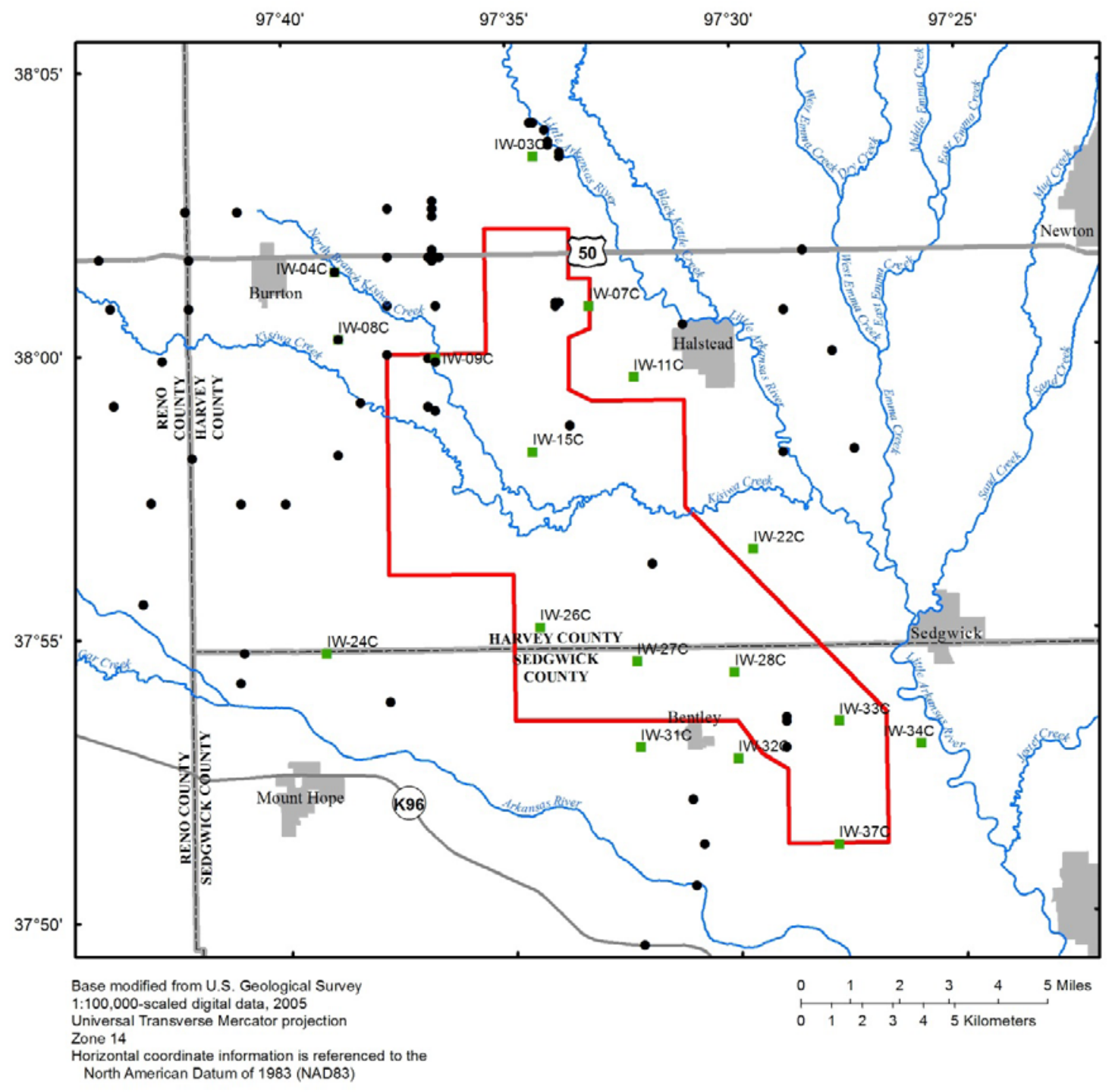

EXPLANATION

Central Wichita well field

Monitoring wells with chloride-concentration data collected during the study period from model layer 3

- Index monitoring wells

- Other monitoring wells

Figure 14. Model showing locations of wells with chloride-concentration data in the study area, model layer 3 , 1990-2008. 


\section{Analysis of Simulated Chloride-Concentration and Head Data}

The simulated chloride concentrations are presented in terms of the rate of movement and the location of the $250-\mathrm{mg} / \mathrm{L}$-chloride front (chloride front) with respect to the WWF. The 250-mg/Lchloride front is important because $250 \mathrm{mg} / \mathrm{L}$ is the U.S. Environmental Protection Agency SMCL for chloride (U.S. Environmental Protection Agency, 2013). Additionally, chloride concentrations of 140 to $350 \mathrm{mg} / \mathrm{L}$ or greater have been known to cause severe injury to plants and decrease crop yields (Bauder and others, 2011).

Rates of movement of the chloride fronts were estimated for the area between the Arkansas River and the southern boundary of the WWF and for the area between the Burrton plume and the WWF (table 2). The north-south distance between the simulated chloride fronts for stress period 1 (end of 1990, hereinafter referred to as 1990 stress period) and stress period 19 (end of 2008, hereinafter referred to as 2008 stress period) was measured along Public Land Survey System (PLSS) section boundaries that crossed the southern boundary of the well field and was used to estimate the rate of movement between the Arkansas River and the southern well field boundary (figs. 15, 16, and 17). Distances were measured between the 1990 and 2008 250-mg/L-chloride fronts along eight section boundaries, by using a 1-mile interval from the eastern boundary of sec. 7, T. 25 S., R. 2 W. to the eastern boundary of sec. 20, T. 25 S., R. 1 W. The average of these distances was divided by the 18 years between the 1990 and 2008 stress periods to estimate the average rate of movement of the chloride front from the Arkansas River northward toward the southern well field boundary.

In the Burrton area, the rate of movement of the chloride front was calculated by measuring the distance between its position at the end of the 1990 stress period and the end of the 2008 stress period, where the main body of the plume had moved farthest toward the WWF. That distance also was divided by the 18 years from the end of the 1990 stress period to the end of the 2008 stress period to estimate a rate of movement. The shape and movement of the Burrton plume differed between pumping scenarios and model layers 1, 2, and 3 so the distance measurement was taken along different lines depending on the location and direction of the movement of the chloride front toward the well field.

The position of the chloride front at the end of the 2008 stress period of each hypothetical scenario (scenarios 2 through 6, as referred to in the "Purpose and Scope" section of this report) was compared to the chloride front at the end of the 2008 stress period of the baseline scenario (scenario 1) by measuring the distance between them in the same areas where the rates were estimated.

Simulated heads for the 2008 stress period were used to compare the differences between the water levels at the locations of the index monitoring wells in the baseline scenario and each of the hypothetical scenarios. Storage volumes for the 2008 stress period were calculated for each index cell within the BSA (fig. 2) for each scenario, and again the results of the baseline scenario were compared to each of the hypothetical scenarios. The volume of water in the aquifer within the index cells of the BSA were calculated by summing the saturated volume of each model cell within an index cell and multiplying that sum by the specific yield of 0.15 . This method does not account for water retained in the unsaturated zone. 
Table 2. Estimated average rates of movement of simulated chloride fronts for each scenario and distance between simulated chloride fronts in baseline and hypothetical scenarios at the end of the 2008 stress period. [--, not determined]

\begin{tabular}{|c|c|c|c|c|c|}
\hline \multirow{3}{*}{ Scenario } & \multirow{3}{*}{$\begin{array}{l}\text { Model } \\
\text { Layer }\end{array}$} & \multicolumn{4}{|c|}{ Chloride Source } \\
\hline & & $\begin{array}{l}\text { Arkansas River, } \\
\text { near Wichita well } \\
\text { field southern } \\
\text { boundary }\end{array}$ & Burrton plume & $\begin{array}{l}\text { Arkansas River, } \\
\text { near Wichita well } \\
\text { field southern } \\
\text { boundary }\end{array}$ & Burrton plume \\
\hline & & $\begin{array}{r}\text { Average rate } \\
\text { simulated } 250-\mathrm{m} \\
\text { chloride front du } \\
\text { (feet } p\end{array}$ & $\begin{array}{l}\text { novement of } \\
\text { grams-per-liter- } \\
\text { g study period } \\
\text { vear) }\end{array}$ & $\begin{array}{r}\text { Distance betw } \\
\text { simulated } 250-m \\
\text { chloride front in } \\
\text { scenari }\end{array}$ & $\begin{array}{l}\text { n end of } 2008 \\
\text { grams-per-liter- } \\
\text { seline and other } \\
\text { (feet)* }\end{array}$ \\
\hline \multirow{3}{*}{$\begin{array}{l}\text { Existing pumping } \\
\text { (baseline) }\end{array}$} & 1 & 660 & 400 & -- & -- \\
\hline & 2 & 780 & 150 & -- & -- \\
\hline & 3 & 660 & 310 & -- & -- \\
\hline \multirow{3}{*}{ No pumping } & 1 & 500 & 520 & $-3,110$ & 2,250 \\
\hline & 2 & 570 & 70 & $-3,840$ & $-1,430$ \\
\hline & 3 & 510 & 190 & $-2,740$ & $-2,360$ \\
\hline \multirow{3}{*}{$\begin{array}{c}\text { Double Wichita } \\
\text { pumping }\end{array}$} & 1 & 810 & 350 & 2,800 & -920 \\
\hline & 2 & 870 & 210 & 1,640 & 1,140 \\
\hline & 3 & 740 & 440 & 1,250 & 2,520 \\
\hline \multirow{3}{*}{$\begin{array}{l}\text { No irrigation } \\
\text { pumping }\end{array}$} & 1 & 590 & 510 & $-1,350$ & 2,090 \\
\hline & 2 & 710 & 100 & $-1,370$ & -780 \\
\hline & 3 & 620 & 260 & -810 & $-1,010$ \\
\hline \multirow{3}{*}{$\begin{array}{c}\text { Double Wichita } \\
\text { and no irrigation } \\
\text { pumping }\end{array}$} & 1 & 770 & 500 & 1,870 & 1,740 \\
\hline & 2 & 850 & 150 & 1,240 & 930 \\
\hline & 3 & 710 & 400 & 730 & 2,040 \\
\hline \multirow{3}{*}{$\begin{array}{l}\text { Increased phase I } \\
\text { artificial recharge }\end{array}$} & 1 & 660 & 430 & 0 & -630 \\
\hline & 2 & 780 & 140 & 0 & -860 \\
\hline & 3 & 660 & 250 & 0 & -890 \\
\hline
\end{tabular}

\footnotetext{
*Negative value indicates that the chloride front did not travel as far as in the baseline scenario. Positive value indicates that
} the chloride front traveled farther than in the baseline scenario. 


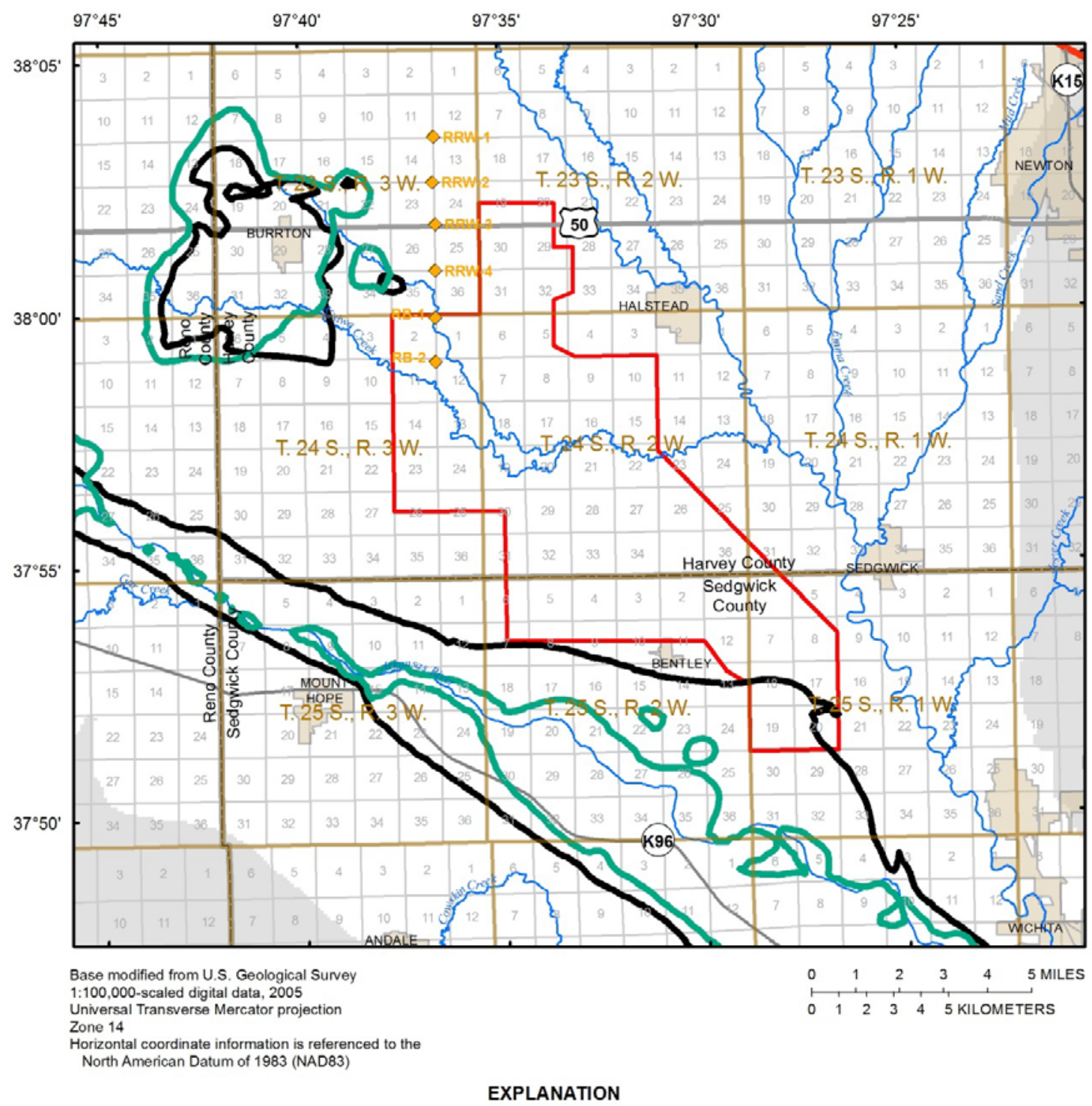

Inactive areas in model layer 1

Central Wichita well field

Simulated chloride front, 1990

Simulated chloride front, 2008

$\diamond \quad$ Phase I recharge site

Figure 15. Map of the end of 1990 stress period and end of 2008 stress period simulated chloride fronts for the existing pumping scenario, model layer 1. 


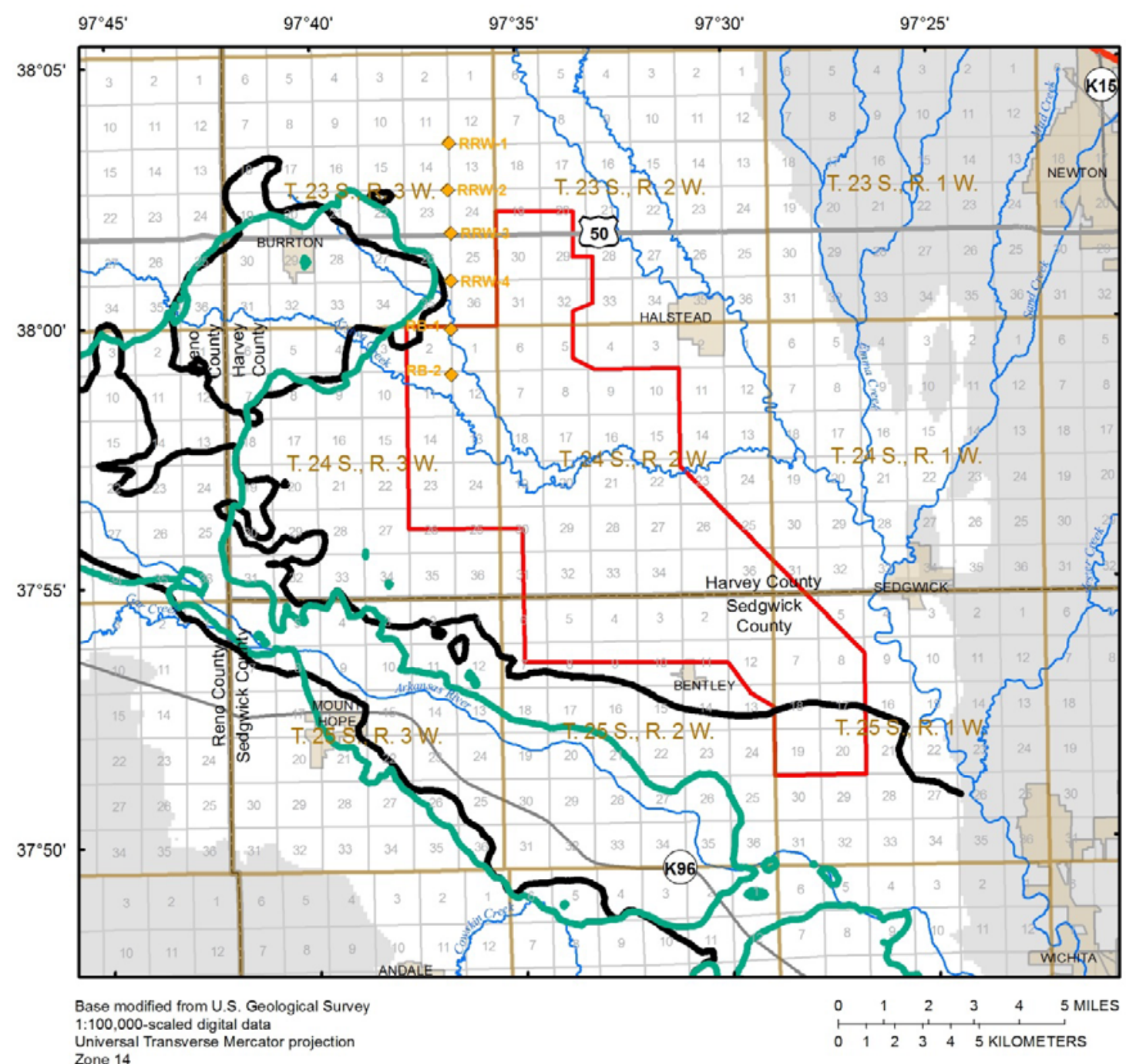

Universal Transverse Mercator projection

EXPLANATION

Inactive areas in model layer 2

Central Wichita well field

Simulated chloride front, 1990

Simulated chloride front, 2008

Phase I recharge site

Figure 16. Map of the end of 1990 stress period and end of 2008 stress period simulated chloride fronts for the existing pumping scenario, model layer 2. 


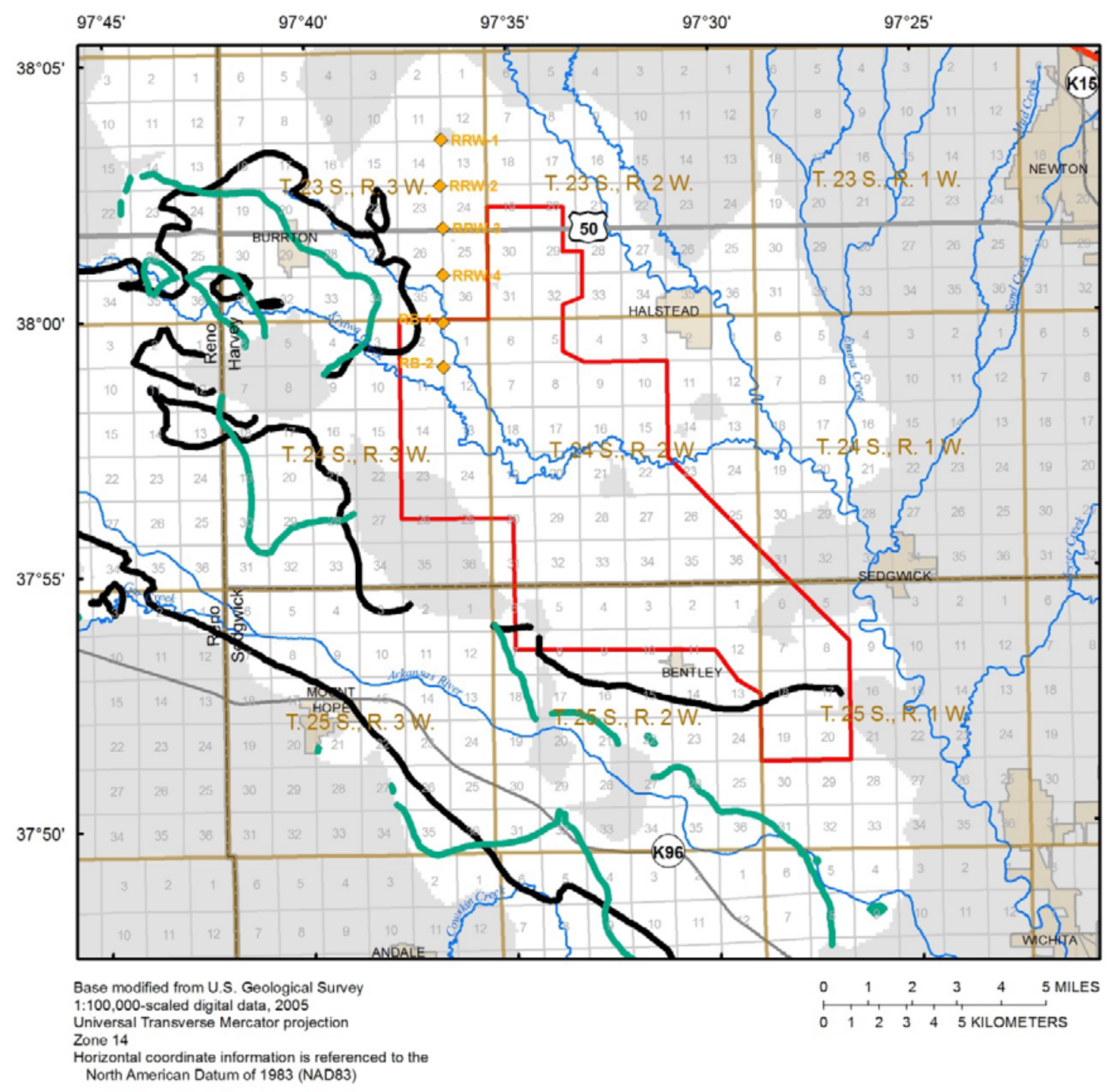

EXPLANATION

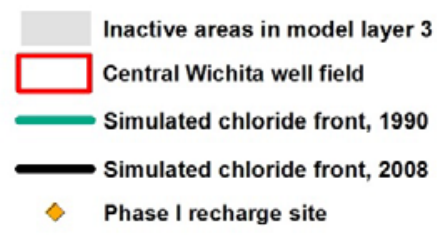

Figure 17. Map of the end of 1990 stress periods and end of 2008 stress periods simulated chloride fronts for the existing pumping scenario, model layer 3. 


\section{Model Limitations}

Any groundwater model is limited in its representation of actual conditions by simplifications, assumptions, and inherent sources of uncertainty. Model limitations should be considered when interpreting model results. Although the chloride-transport model is uncalibrated, a comparison of the simulated chloride concentrations to observed chloride concentrations in groundwater samples in the model area during the study period can provide information about the limitations of the groundwaterflow model (Kelly and others, 2013) and are useful in examining differences and potential effects of different pumping scenarios on groundwater levels and chloride transport.

A potential problem for a calibrated groundwater model is nonuniqueness. A nonunique model is one in which multiple sets of input parameter values yield similar calibration results. Without additional data, determining the set of parameters that is closest to reality may be difficult. A comparison of the simulated and observed chloride-concentration data shows that the groundwater-flow velocities in some areas of the model are too fast. Therefore, despite the agreement between simulated and observed groundwater levels in the groundwater-flow model (Kelly and others, 2013), the model is likely nonunique, and new input parameter values could be determined through recalibration of the model using additional data in future updates.

Spatial and temporal discretization place limits on the scale and duration of hydrologic events that can be simulated by the model. Any event that takes place on a smaller scale than the $400 \mathrm{ft}$ by 400 $\mathrm{ft}$ cells in the model grid cannot be captured in the simulation, and any event that takes place on a shorter time scale than the annual stress periods used in the model also cannot be simulated. These events can be part of the average stresses over the model cell or stress period, but the effects of the individual events cannot be discerned. For example, drawdown effects around a single well will likely not be simulated in enough detail to be useful for conditions near or at a well. Likewise, the effects of individual precipitation events of relatively short durations cannot be analyzed using results from this model. In addition, because the properties of the aquifer are assumed to be homogeneous within each model cell, effects of local heterogeneities of the aquifer cannot be simulated.

Many of the input data to this model were interpolated over the volume of the aquifer using sparse point data, and the values of some input parameters were determined through the model calibration process, rather than through field measurements. Furthermore, those input values that are based on field measurements or laboratory analysis of groundwater samples are subject to the uncertainty inherent to the methods used for each of the measurements.

Solute-transport models have a higher degree of inherent uncertainty than groundwater-flow models because they rely on more parameters with associated uncertainty, which include initial solute concentrations that were interpolated from sparse point data, and aquifer properties not included in the groundwater-flow model (such as effective porosity and dispersion). In comparison to a groundwaterflow model, a groundwater-solute-transport model is not expected to display equivalent reliability (Konikow, 2011). Because of this uncertainty, the results of hypothetical scenarios need to be used in general terms of increases or decreases in transport rate relative to the baseline scenario, rather than in terms of specific transport rates. Additionally, the results need to be used as approximations of conditions rather than specific chloride concentrations. 


\section{Description of Preliminary Simulation of Chloride Transport in the Equus Beds Aquifer with Existing Well Pumping and Artificial Recharge}

The results of the baseline scenario, in which the actual conditions for 1990 through 2008 were simulated, were compared to observed data to assess how well the chloride transport and groundwater levels were simulated. Southwest of the WWF (fig. 1), the Arkansas River is a major source of chloride to the aquifer (Myers and others, 1996). In this scenario, existing municipal pumping (by Wichita within the WWF), existing irrigation and industrial pumping, and existing artificial recharge were simulated. By the 2008 stress period, the simulated chloride front had moved farther northeast than the position of the front interpreted from observed chloride concentrations from 2011 (figs. 18 and 19). The chloride fronts interpreted from observed chloride data from 2011 were used for comparison with the simulation because 2011 was the most complete year of sampling in the areas of interest, and provided the best estimation of plume shape for visual comparison with the simulated chloride plume. The 2011 chloride fronts were mapped prior to this study (unpublished) and used two layers - shallow (0 to $80 \mathrm{ft}$ below land surface) and deep ( $80 \mathrm{ft}$ and deeper below land surface) _ instead of the three modeling layers used in Kelly and others (2013) and in this chloride-transport model. The contours for the shallow layer created by using observed data (2011) were compared to simulated contours from model layer 1 (fig. 18). The contours for the deep layer created by using observed data (2011) were compared to simulated contours from layer 3 (fig. 19). In the simulation, the chloride front moved north toward the southern well field boundary at approximately $660 \mathrm{ft} / \mathrm{yr}$ in layer 1; $780 \mathrm{ft} / \mathrm{yr}$ in layer 2; and $660 \mathrm{ft} / \mathrm{yr}$ in layer 3 (table 2). In order for the simulated chloride front to agree with the contours created from 2011 observed data in the Arkansas River area, the simulated front would have to travel between the river and the southern boundary of the well field at an average rate of approximately $310 \mathrm{ft} / \mathrm{yr}$ in the shallow layer and $160 \mathrm{ft} / \mathrm{yr}$ in the deep layer, about 50 percent and 75 percent slower, respectively, than rates of movement of the front in that area of the baseline simulation.

The simulated Burrton plume is fairly similar in shape and position as determined by Whittemore (2012) and Ziegler and others (2010); however, the plume moves in a different direction and does not match the observed data (2011) in some areas (figs. 18 and 19). In the shallow layer (fig. 18), the simulated chloride front extends southeast toward the well field, whereas the chloride front based on 2011 observations extends farther south. Also, in the northeastern part of the plume, some of the simulated groundwater with greater than $250-\mathrm{mg} / \mathrm{L}$-chloride concentration sinks into the deeper layers over the course of the simulation, whereas it is still present in the chloride front interpreted from the 2011 observed data.

In the deep layer (fig. 19), the simulated Burrton plume and the Burrton plume interpreted from 2011 observed data both extend east toward the well field, although the plume based on observed data moved farther north. The simulated chloride front moved toward the well field at an approximate average rate of $400 \mathrm{ft} / \mathrm{yr}$ in layer 1; $150 \mathrm{ft} / \mathrm{yr}$ in layer 2; and $310 \mathrm{ft} / \mathrm{yr}$ in layer 3 (table 2). Quantitative comparisons of the simulated and actual rates of movement of the chloride fronts in the Burrton area were difficult to make because the plumes appeared to be spreading in different directions. The simulated plume moved toward the well field along a more direct path than what the observed data show (fig. 19).

The movement of chloride mass into and out of the model were well balanced, with much less than one percent discrepancy between them at each time step (on the order of $10^{-10}$ to $10^{-8}$ percent). A negligible chloride mass-balance was expected, because the standard finite-difference method was used for the calculations, which starts from a mass-balance equation for each model cell (Zheng and Wang, 1999). 


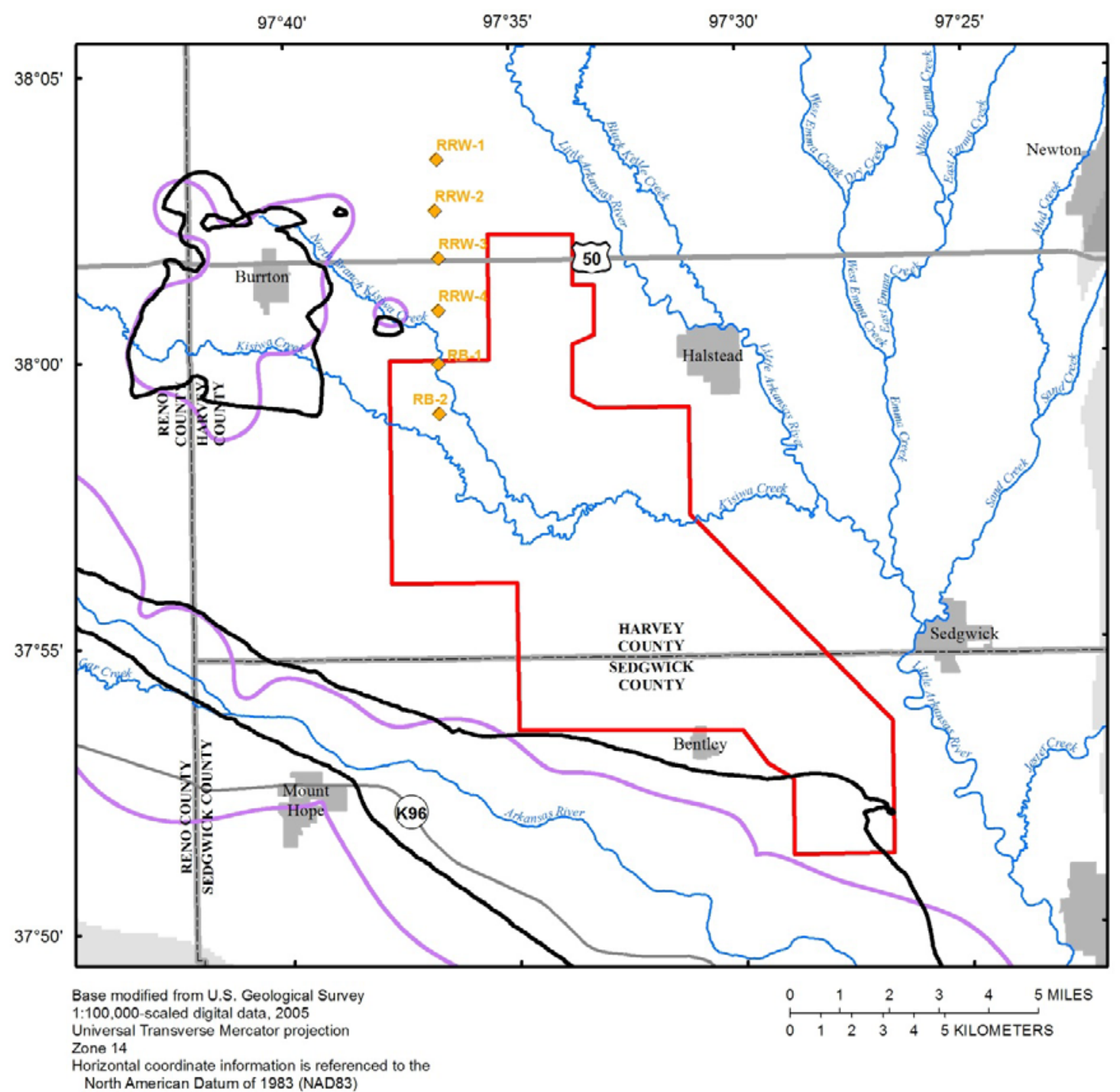

EXPLANATION

Inactive areas in model layer 1

Central Wichita well field

Simulated chloride front (2008),

existing pumping scenario

Chloride front based on chloride data (2011)

from shallow parts of the Equus Beds aquifer

$\Delta \quad$ Phase I recharge site

Figure 18. Map of simulated chloride front for baseline scenario from the end of the 2008 stress period and chloride front based on shallow chloride data from 2011, model layer 1. 


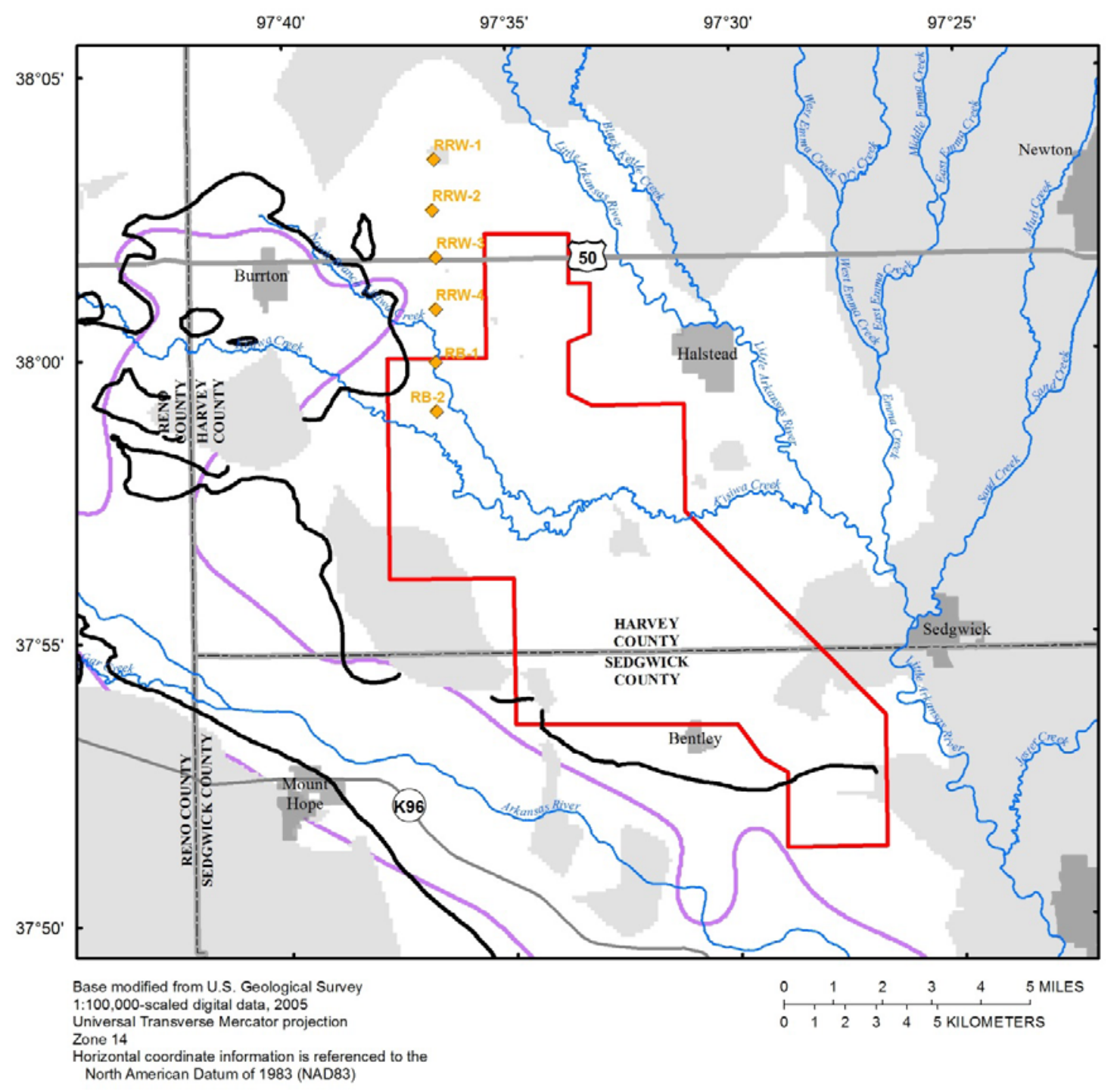

EXPLANATION

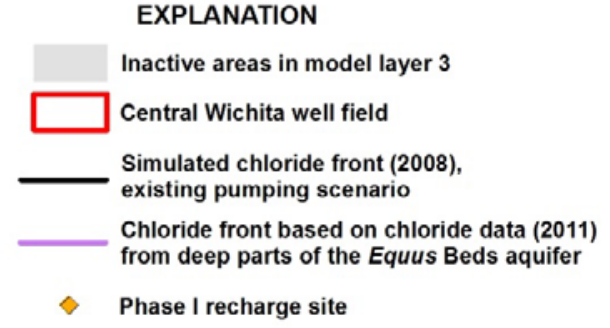

Figure 19. Map of simulated chloride front for baseline scenario from the end of the 2008 stress period and chloride front based on deep chloride data from 2011, model layer 3. 
As discussed in the section, "Modifications to Groundwater-Flow Model for Use with the Chloride-Transport Model," the groundwater-flow model of Kelly and others (2013) was used for the flow portion of this chloride-transport model, and the head calibration and comparison between observed and simulated water levels by Kelly and others (2013) also applied to the pumping scenario described here. The simulated groundwater levels were highest in the northwest corner of the model area and generally decreased toward the southeast. The RMS error for water-level observations for Kelly and others (2013) was $2.48 \mathrm{ft}$.

\section{Comparison of Observed Chloride Concentrations from 1990 through 2008 to Simulated Chloride Concentrations from the Baseline Scenario}

Observed and simulated chloride concentrations were compared by calculating the difference between simulated and observed chloride concentrations (called residuals) in model cells where groundwater samples were collected and analyzed for chloride during 1990 through 2008. Chloride concentration residuals were plotted as a function of simulated chloride concentration in figure 20 . Different symbols were used in the plot to indicate the areas where the large residuals occurred and thus show areas of poor agreement between observed and simulated data.

Although the chloride transport simulation is uncalibrated, a comparison of the simulated chloride concentrations to observed chloride concentrations in groundwater samples in the model area during the study period can yield information about the limitations of the Kelly and others (2013) groundwater-flow model and chloride transport. The addition of chloride transport to the groundwaterflow model (Kelly and others, 2013) revealed areas where recalibration of the groundwater-flow model is required for adequate simulation of solute transport. Flow model parameters such as hydraulic conductivity and riverbed properties have a high degree of influence over solute transport in the aquifer; therefore, a new calibration of groundwater-flow parameters is necessary to achieve a better agreement between simulated and observed chloride concentrations. A better understanding of the limitations of the groundwater-flow model can help estimate parameter values in future updates of the model, and determine appropriate uses for the model until such updates are made.

Areas with large chloride-concentration residuals may require adjustment of the groundwaterflow model parameters to improve the agreement between observed and simulated data. The largest residuals occurred in layer 3 near a plume about 6 miles north of Burrton, Kansas in an area known as the Hollow-Nikkel area (fig. 1). High chloride concentrations were found in water from wells completed in layer 3 in the Hollow-Nikkel area (figs. 21 and 22). Observed chloride concentrations in wells EB34C, EB35C, EB36C, and EB45B were all greater than 1,000 mg/L (as much as 7,600 mg/L in EB34C, fig. 22), while chloride concentrations in surrounding monitoring wells generally were less than $100 \mathrm{mg} / \mathrm{L}$, which suggests that a slow moving or static plume exists in the area. However, simulated chloride concentrations (fig. 22) suggested more rapid transport, with downward trends in wells that had consistently high observed chloride concentrations and upward trends in many of the wells that had consistently low observed chloride concentrations. 


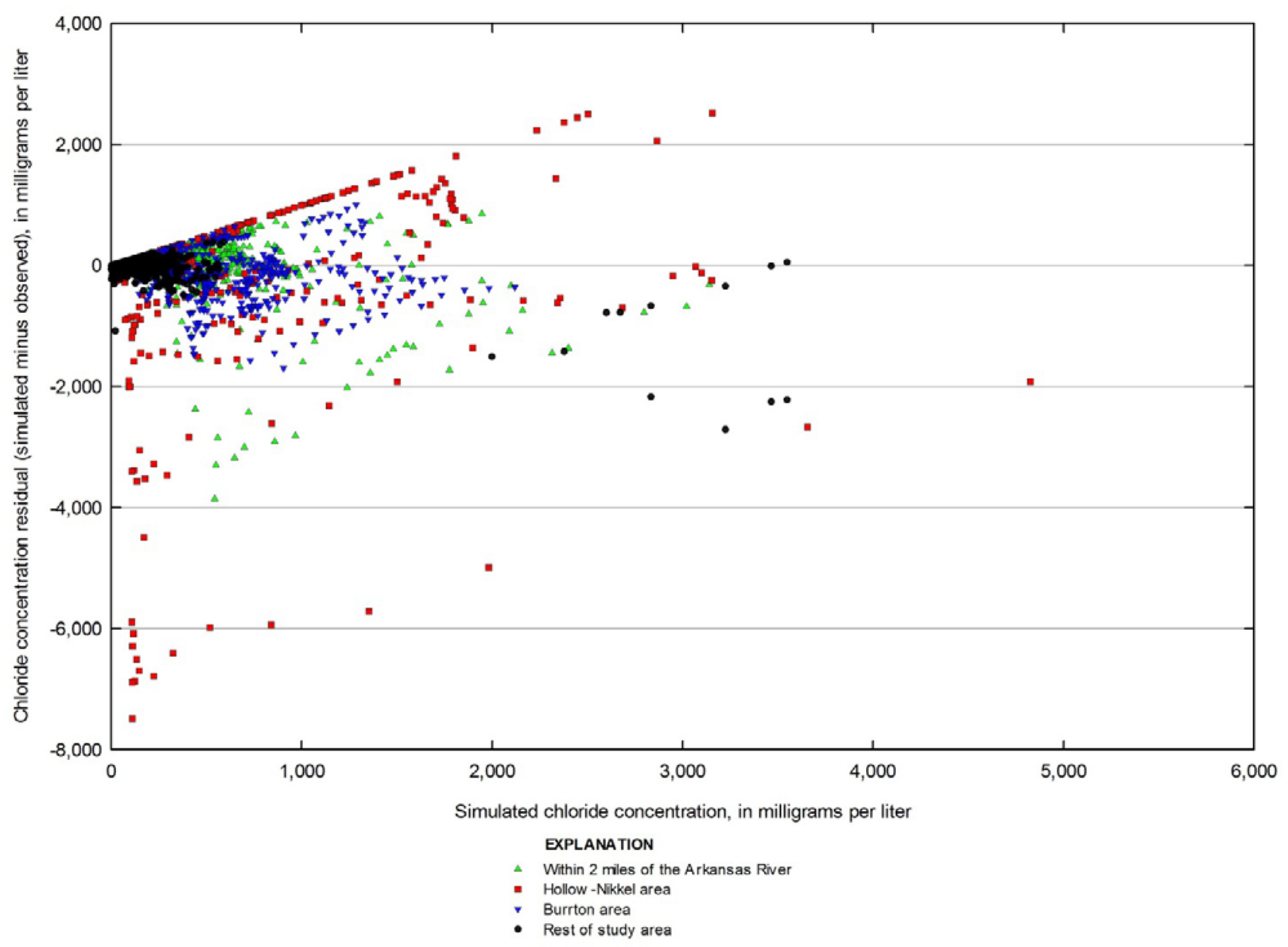

Figure 20. Graph showing comparison of simulated chloride concentration to residuals of chloride concentration (simulated minus observed concentrations at each sample location), 1990 through 2008. 


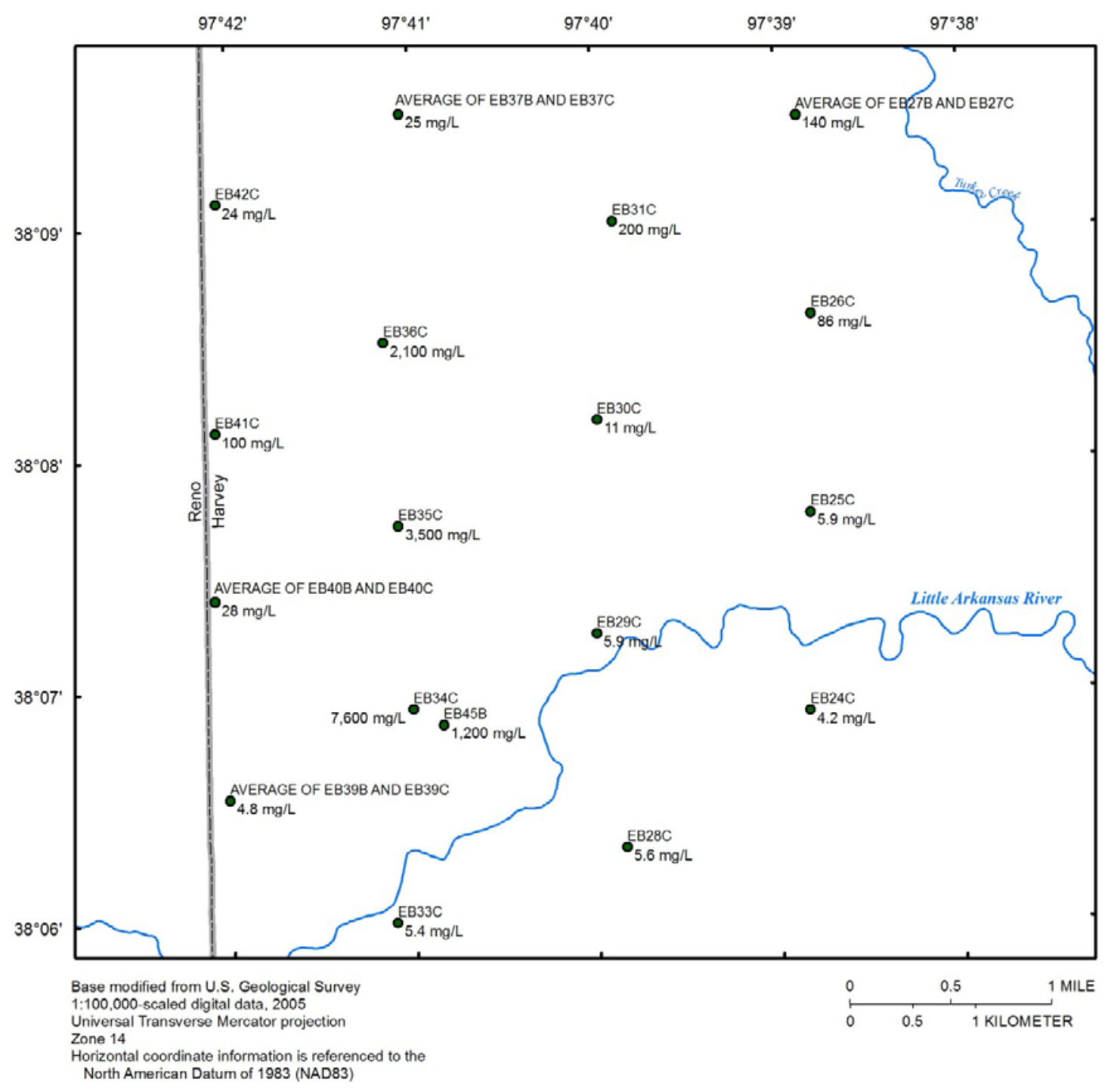

EXPLANATION

EB28C Monitoring well locations with site names and 2008

$5.6 \mathrm{mg} / \mathrm{L}$ observed chloride concnetrations in milligrams per liter

Note: Wells labeled as "Average of ...." are locations

where multiple wells are in the same model cell.

Figure 21. Map showing locations of monitoring wells in the Hollow-Nikkel area and observed chloride concentrations, model layer 3. 

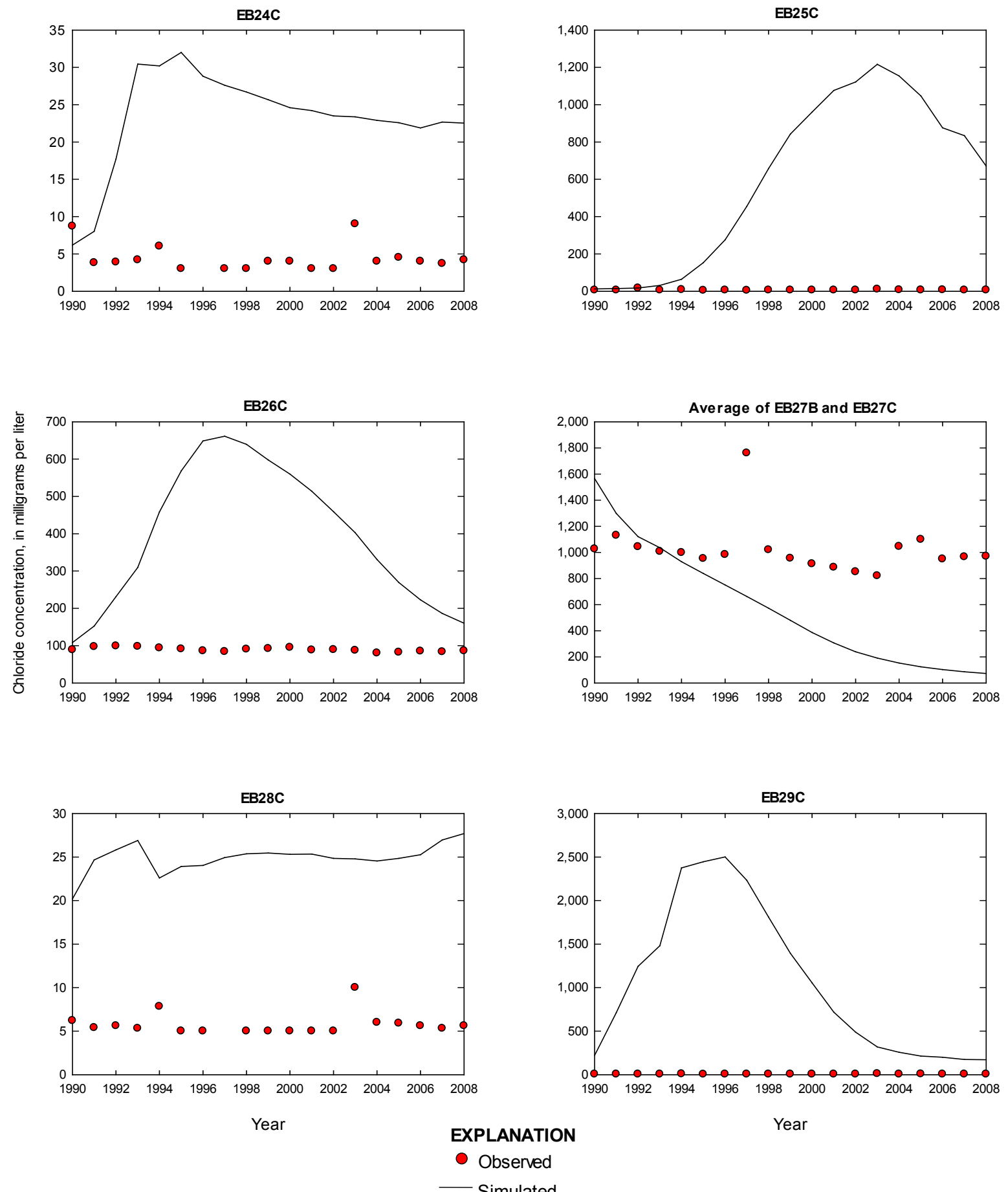

Figure 22. Graphs showing observed chloride concentrations and simulated chloride concentrations from the baseline scenario in monitoring wells in the Hollow-Nikkel area. 

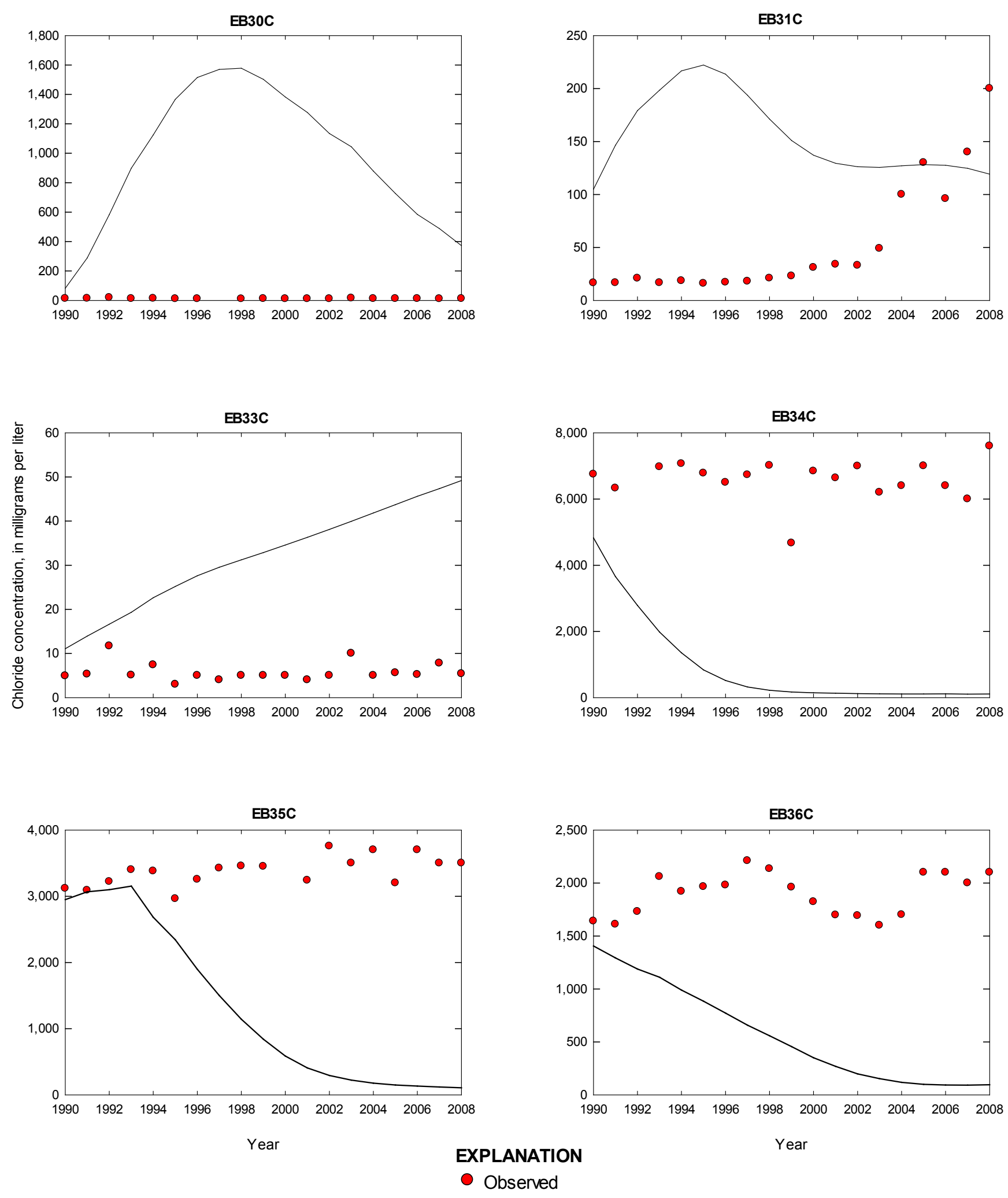

EXPLANATION

- Observed

- Simulated

Figure 22. -Continued 

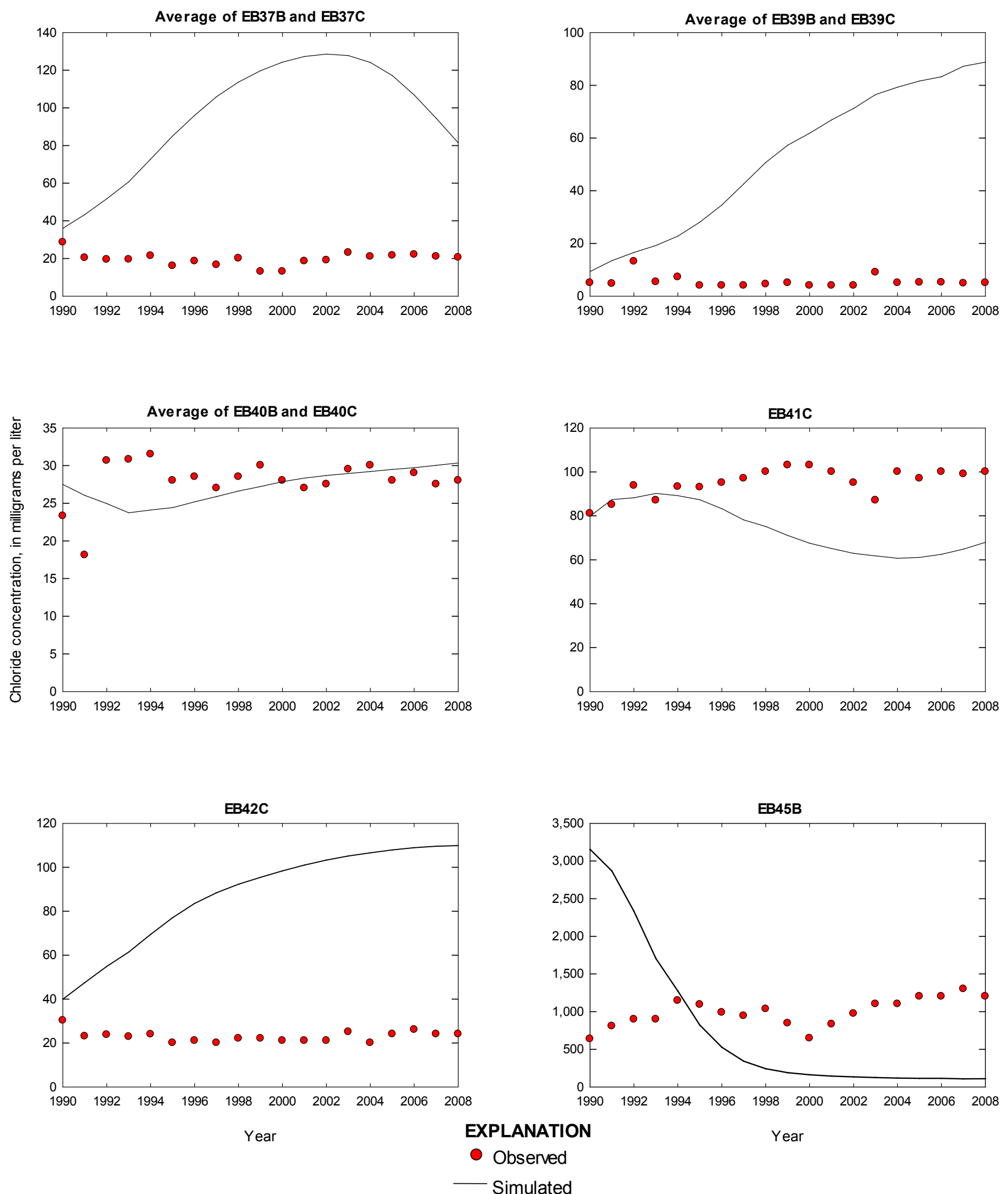

Figure 22. -Continued 
The comparison of observed and simulated chloride concentrations indicated the simulated groundwater-flow velocity through the Hollow-Nikkel area was too high. Kelly and others (2013) included the Hollow-Nikkel area in a calibration zone called the "North Uplands" that had a root mean square error (RMSE) of $8.35 \mathrm{ft}$, which was the highest RMSE of any of the six calibration zones used in for the groundwater flow model. The high RMSE indicates that, on average, wells in this calibration zone had the largest head residuals. The simulated head difference between EB41C and EB25C (locations shown in fig. 21) remained less than this RMSE from the 1990 stress period through the 2008 stress period, and ranged from 4.36 to $6.69 \mathrm{ft}$. Because the head difference across the Hollow-Nikkel area plume is lower than the RMSE, the direction and magnitude of the simulated hydraulic gradient across the Hollow-Nikkel area could likely be changed without negatively impacting the head error in the area.

There were large differences between observed and simulated chloride concentrations in wells along the Arkansas River (locations shown in figs. 12, 13, and 14). In the simulation, chloride from the river was transported toward the southern boundary of the WWF at a faster rate than was indicated by observed chloride concentrations. Over the course of the simulation, the simulated chloride concentrations at index monitoring wells between Arkansas River and the southern boundary of the WWF increased faster than the observed chloride concentrations (fig. 23).

There also are areas along the Little Arkansas River with large residuals. Simulated chloride moved westward from the river towards the WWF near Halstead and Sedgwick. Observed chloride concentration data from index monitoring wells near the Little Arkansas River (locations shown in figs. 12,13 , and 14) indicate relatively low chloride concentrations just west of the river, but simulated chloride concentrations were substantially higher. For example, simulated concentrations at IW-12A (model layer 1) near Halstead were as much as $120 \mathrm{mg} / \mathrm{L}$ while samples from that well had concentrations less than $30 \mathrm{mg} / \mathrm{L}$ (fig. 24).

Last, smaller chloride concentration residuals near the Burrton plume showed a better match between observed and simulated chloride concentrations than in other areas of interest. Observed chloride concentrations from index monitoring wells (locations shown in figs. 12, 13, and 14) completed in layer 1 that are closest to the plume documented a better agreement with simulated concentrations than those that were completed in layer 3 (fig. 25). 

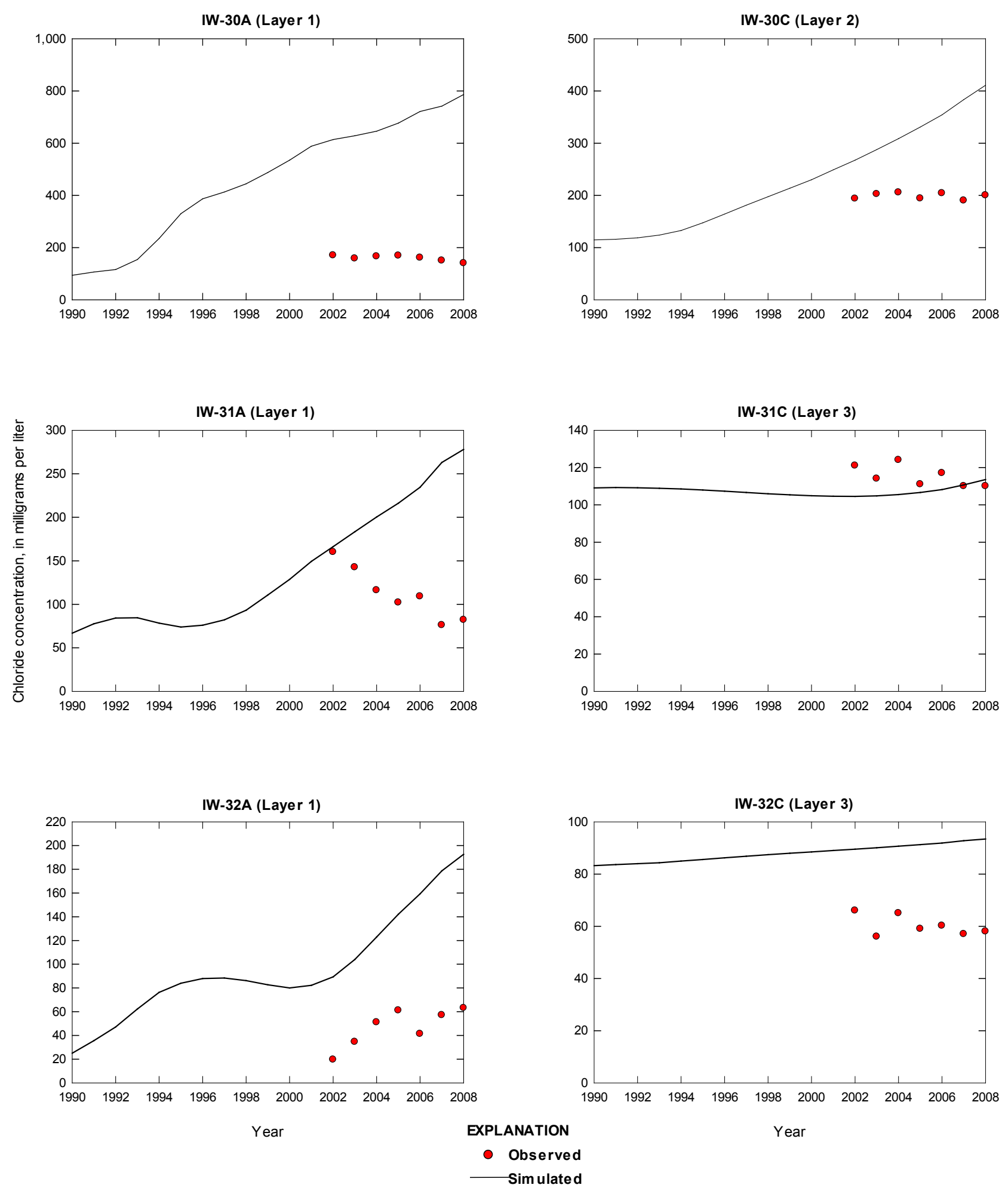

Figure 23. Graphs showing observed and simulated chloride concentrations for the baseline scenario for index monitoring wells between the Arkansas River and the southern boundary of the Wichita well field. 

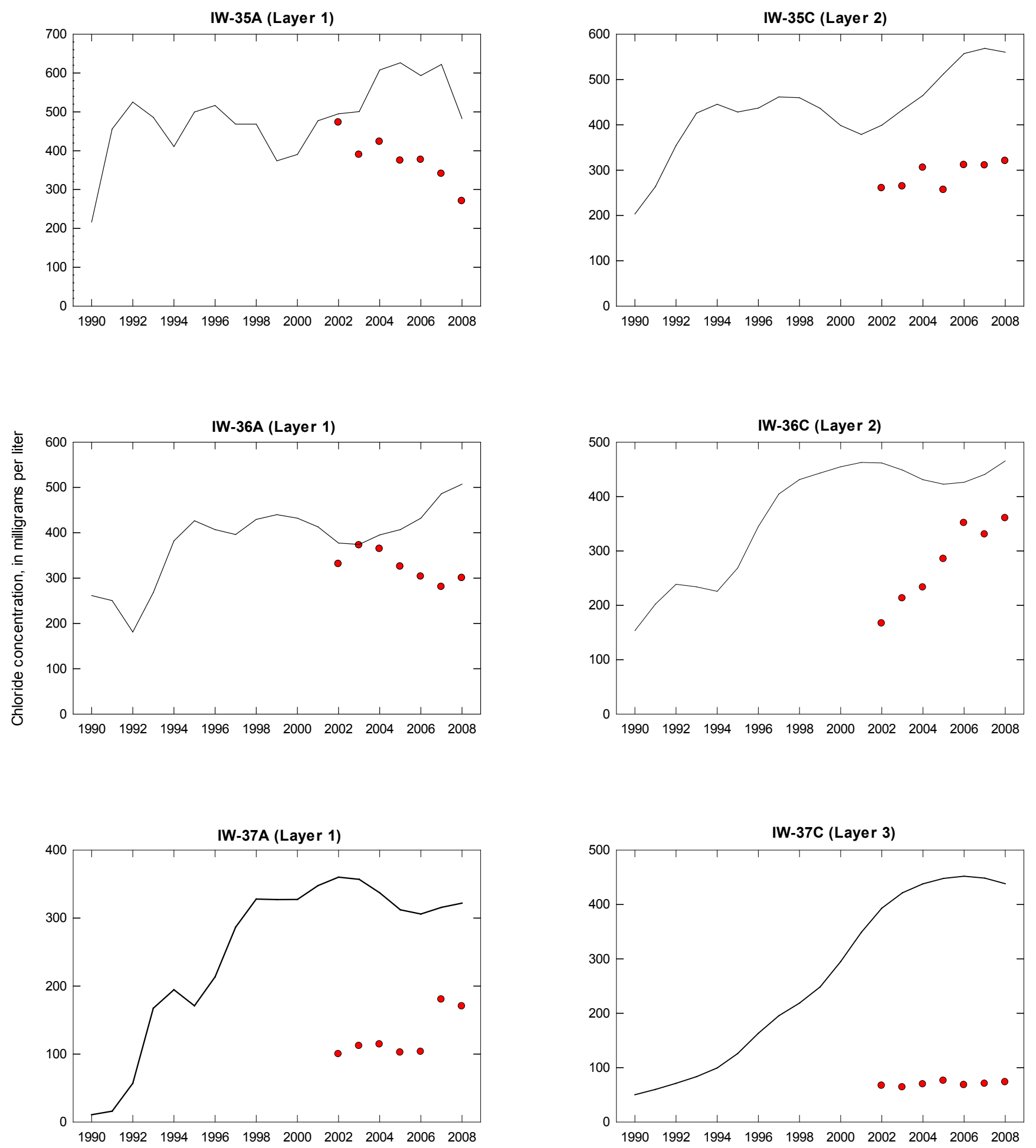

$$
\text { Year }
$$

EXPLANATION

Year

- Observed

Sim ulated

Figure 23 - Continued 
IW-12A Shallow (model layer 1)

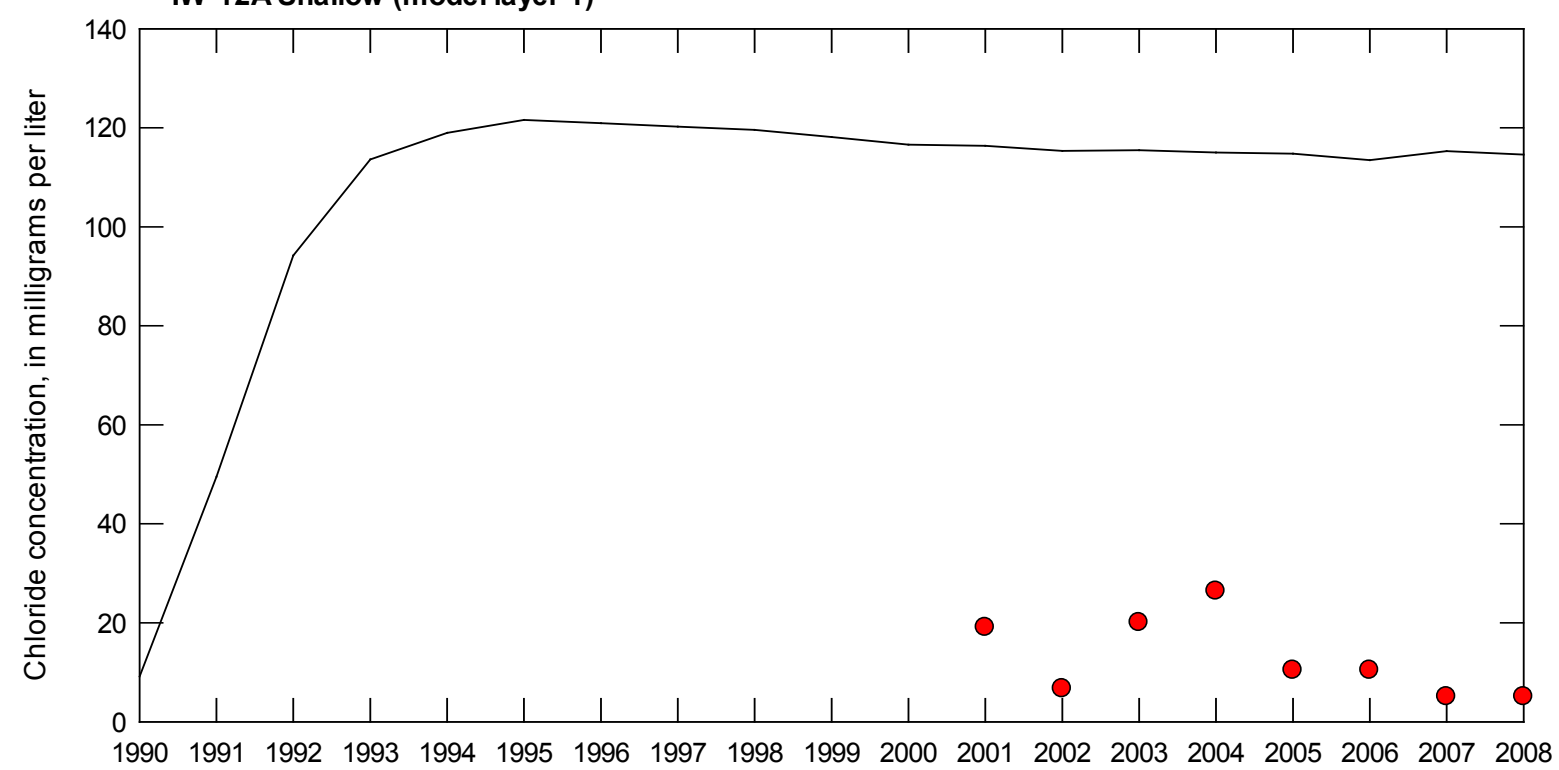

IW-12C Deep (model layer 3)

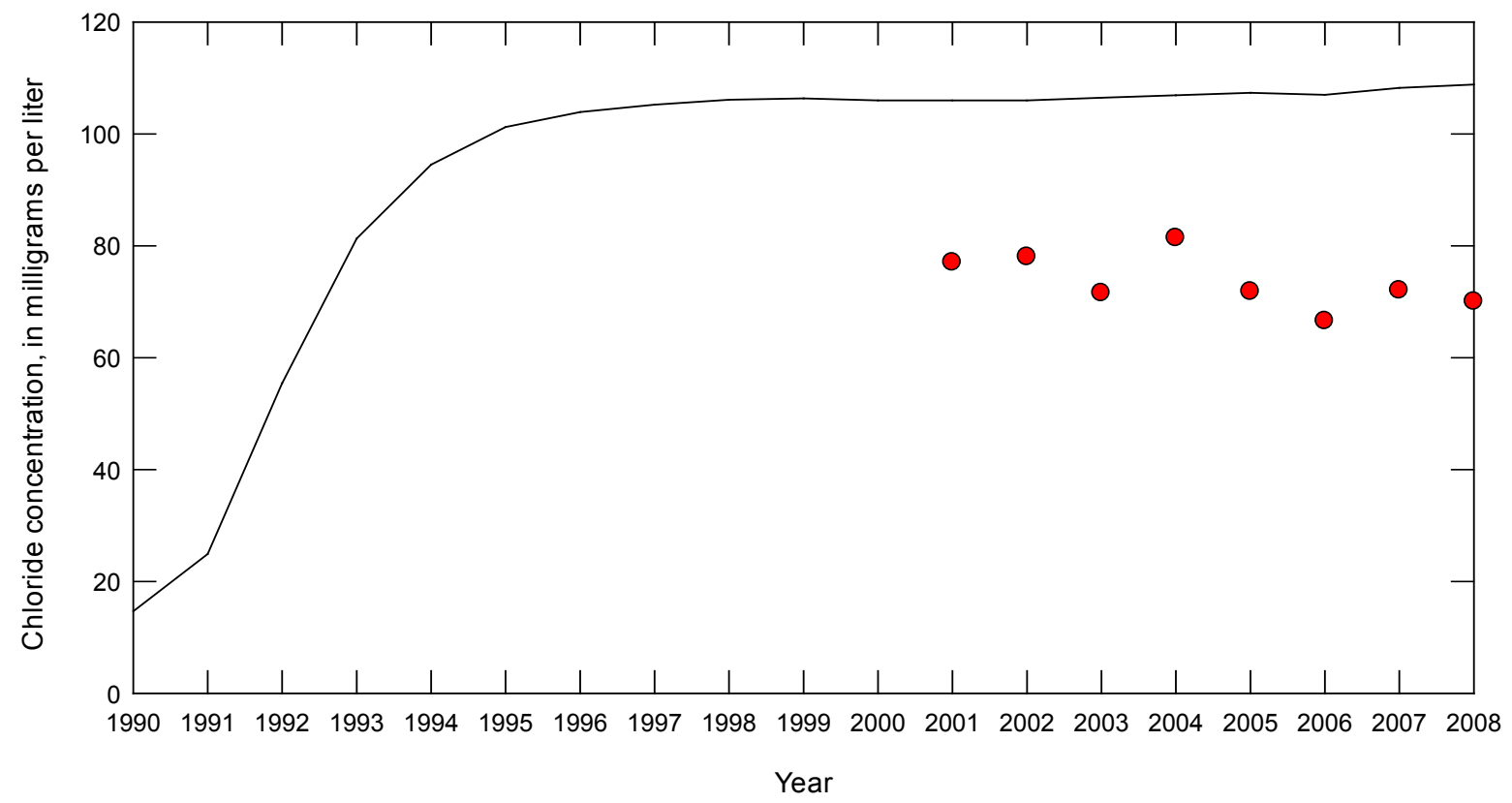

EXPLANATION

- Observed

Simulated

Figure 24. Graphs showing observed and simulated chloride concentrations for the baseline scenario for index monitoring wells near the Little Arkansas River in Halstead. 

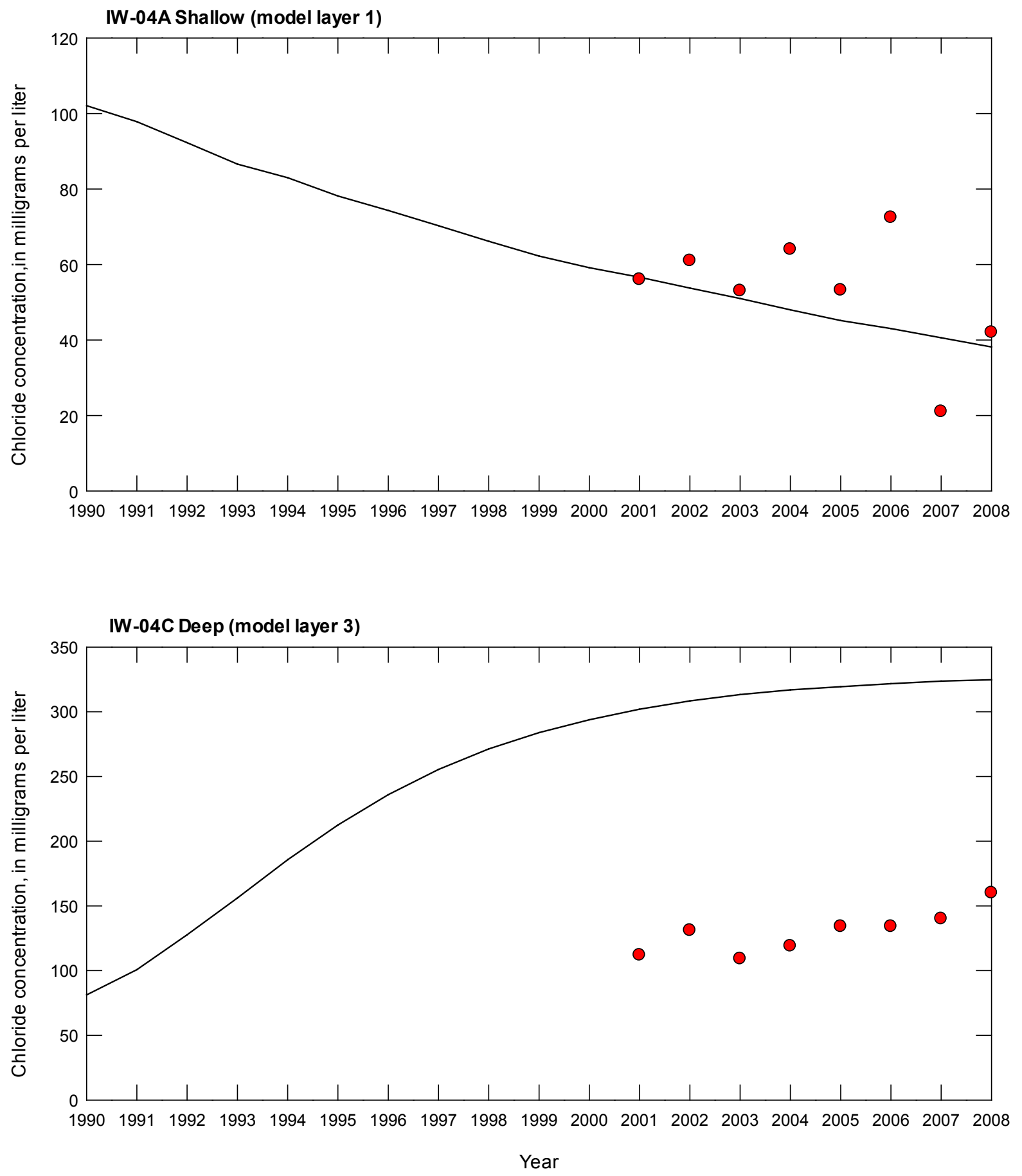

EXPLANATION

- Observed

Simulated

Figure 25. Graphs showing observed and simulated chloride concentrations for the baseline scenario for index monitoring wells near the Burrton plume. 

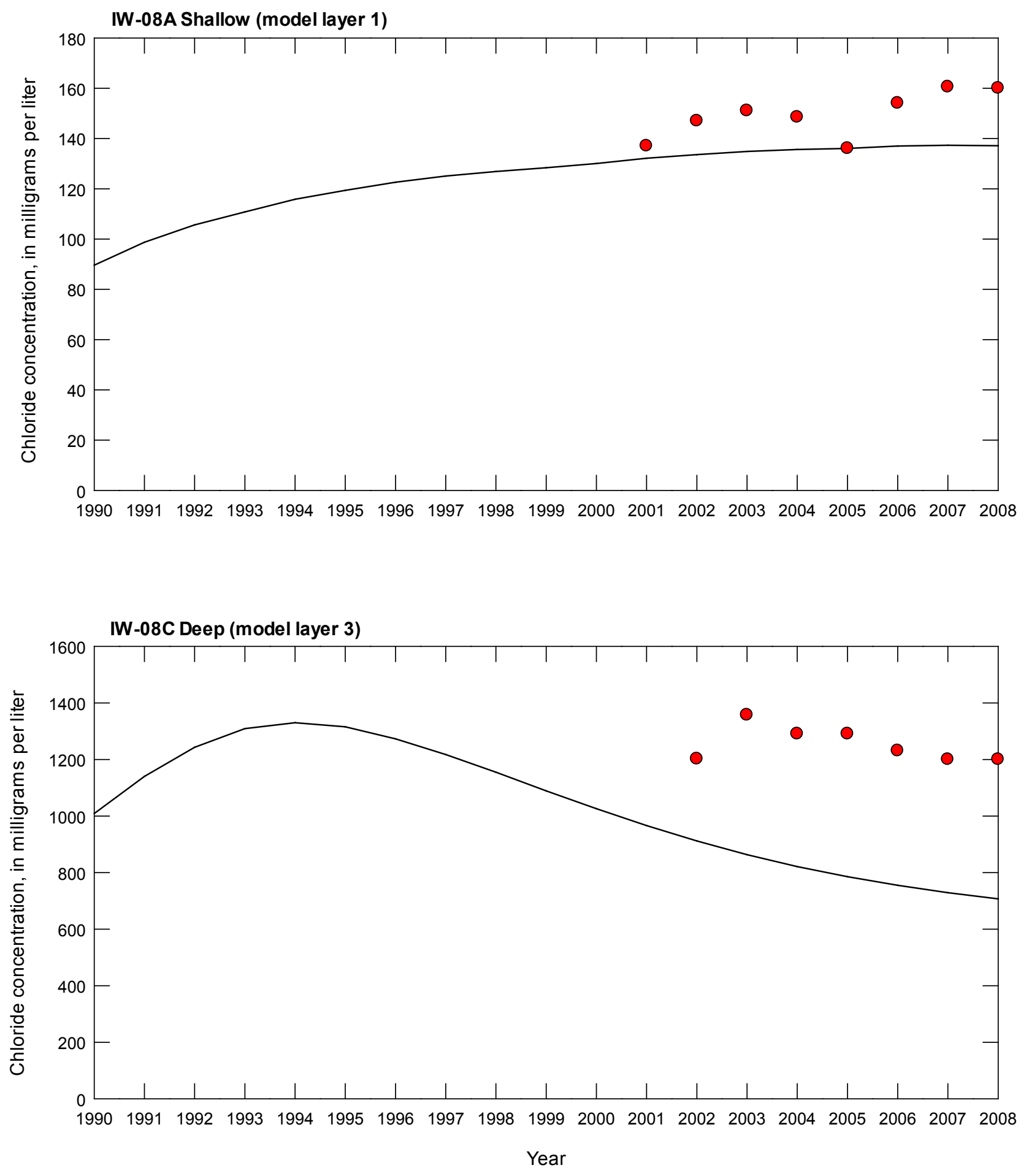

EXPLANATION

- Observed

Simulated

Figure 25 -Continued 


\section{Potential Improvements to the Groundwater-Flow Model}

Assuming that the initial chloride distribution (figs. 9, 10, and 11) used for the simulation was reasonable and chloride transport in the aquifer is dominated by advection, then chloride-concentration residuals from this simulation can be used to help to refine the groundwater-flow parameters in future efforts to model groundwater flow and solute transport in the Equus Beds aquifer. Simulated chloride transport that was too fast or slow in a particular direction indicated that the groundwater velocity in that direction was too fast or slow. This could mean that the hydraulic properties of the aquifer need to be adjusted to change groundwater-flow velocities. Changes to aquifer characteristics that affect flow most likely will change the simulated heads and hydraulic gradients; thus, both chloride concentration and head residuals need to be considered during recalibration of the model to ensure that changing parameters to improve chloride-concentration residuals does not have overly adverse effects on head residuals.

Hydraulic conductivities could be changed to adjust groundwater-flow velocity in areas where chloride concentration residuals are large. In the Hollow-Nikkel area and the area between the Arkansas River and the southern boundary of the WWF, lower hydraulic conductivities would slow the groundwater-flow velocity and decrease advective transport. Areas with negative chloride concentration residuals (fig. 20) may require increases in hydraulic conductivity to increase advective transport. The hydraulic conductivity and thickness of the streambed of the Arkansas River also might be adjusted to increase or decrease streamflow losses and the chloride transport from the river into the aquifer, depending on whether residuals for chloride concentration were positive or negative at sampled wells near a particular reach of the Arkansas River.

More detailed information about the distribution of other aquifer properties, such as effective porosity and specific yield, might help to improve agreement between observed data and simulated results and lower the chloride concentration residuals. For this analysis the effective porosity was assumed to be equal to the specific yield. Effective porosity can be higher than the specific yield in finer-grained materials. Higher effective porosity values would slow the groundwater-flow velocity and decrease advective transport. The effective porosity value was not used in the groundwater-flow calculations, so the simulated heads would not be changed by adjusting effective porosity. A value of 0.15 was used for specific yield for the aquifer in this simulation. A more detailed distribution of specific yield might be developed through recalibration, which would affect the groundwater-flow and storage-volume calculations.

\section{Simulated Effects of Hypothetical Well-Pumping and Artificial-Recharge Scenarios on Groundwater Flow and Chloride Transport}

The groundwater-flow and chloride-transport model was used to simulate the effects on groundwater flow and chloride transport within the Equus Beds aquifer for five well-pumping scenarios and one artificial-recharge scenario for the 1990 through 2008 stress periods. Unless otherwise indicated, existing industrial pumping, existing municipal pumping outside the WWF, and existing artificial recharge were used in all five well pumping scenarios. All municipal pumping within the WWF is by the city of Wichita. The five well pumping scenarios were: (1) existing Wichita municipal pumping and existing irrigation pumping to serve as a baseline for comparison with the other scenarios (described in section, "Description of Preliminary Simulation of Chloride Transport in the Equus Beds Aquifer with Existing Well Pumping and Artificial Recharge"), (2) no pumping in the model area for 
the study period to demonstrate chloride transport without the influence of pumping, (3) doubling Wichita municipal pumping with existing irrigation pumping, (4) existing Wichita municipal pumping with no irrigation pumping, and (5) doubling Wichita municipal pumping with no irrigation pumping. Last, the artificial-recharge scenario simulated increasing artificial recharge to the Phase 1 ASR sites by 2,300 acre-ft/yr with existing Wichita municipal pumping, existing municipal pumping outside the WWF, and existing irrigation and industrial pumping, to demonstrate how artificial recharge at Phase 1 recharge sites (fig. 2) may affect the movement of the Burrton plume. These six scenarios were designed to demonstrate the effects that changes in well pumping and artificial recharge might have on chloride transport in the Equus Beds aquifer, specifically in the area in and around the WWF. Well pumping and artificial recharge rates for each scenario are summarized in table 3 . The differences in the results in simulated groundwater flow and chloride transport by using the existing 1990 through 2008 wellpumping rates and hypothetical pumping-rate scenarios determine possible areas where the groundwater flow and chloride transport are sensitive to changes.

\section{No Pumping Scenario}

In this hypothetical scenario, simulated chloride from the Arkansas River and the Burrton plume was transported toward the Wichita well field at a slower rate when compared to the baseline scenario. In model layer 1, the chloride front near the southern part of the well field moved northward from the Arkansas River toward the well field at about $500 \mathrm{ft} / \mathrm{yr}$ (160 ft/yr slower than in the baseline scenario), in layer 2 at about $570 \mathrm{ft} / \mathrm{yr}$ (210 ft/yr slower than in the baseline scenario), and in layer 3 at about 510 $\mathrm{ft} / \mathrm{yr}$ (150 ft/yr slower than in the baseline scenario) (table 2). The 250-mg/L-chloride front of the Burrton plume in layer 1 moved southeast toward the well field at a rate of approximately $520 \mathrm{ft} / \mathrm{yr}$ (120 $\mathrm{ft} / \mathrm{yr}$ faster than in the baseline scenario), in layer 2 at about $70 \mathrm{ft} / \mathrm{yr}(80 \mathrm{ft} / \mathrm{yr}$ slower than in the baseline scenario), and in layer 3 at about $190 \mathrm{ft} / \mathrm{yr}$ (120 ft/yr slower than in the baseline scenario) (table 2).

Elimination of all groundwater pumping in the model area decreased the rate of chloride transport towards the well field compared to the movement simulated in the baseline scenario in the southern part of the well field near the Arkansas River. In layer 1, by the end of the 2008 stress period the 250-mg/L-chloride front in the baseline scenario moved (table 2) approximately 3,110 ft farther north than the no pumping scenario (fig. 26). In layer 2, the $250-\mathrm{mg} / \mathrm{L}$-chloride front moved approximately $3,840 \mathrm{ft}$ farther north in the baseline scenario than in the no pumping scenario (fig. 27). In layer 3, the 250-mg/L-chloride front moved approximately 2,740 ft farther north in the baseline scenario than in the no pumping scenario (fig. 28).

Additionally, at the end of the 2008 stress period using this scenario, the simulated Burrton plume in layer 1 moved farther toward the well field than in the baseline scenario, and the plume in layers 2 and 3 moved farther toward the well field in the baseline scenario than in this scenario. In model layer 1, the chloride front moved as much as 2,250 ft farther east in this scenario than in the baseline scenario (fig. 26). In layer 2, by the end of 2008 the $250-\mathrm{mg} / \mathrm{L}$-chloride front moved as much as $1,430 \mathrm{ft}$ farther southeast toward the well field in the baseline scenario than in the no-pumping scenario, although an arm of the southern part of the plume, about 3,500 ft north of IW-13, extended southeast as much as 2,640 ft farther in the no pumping scenario than in the baseline scenario (fig. 27). In layer 3, by the end of 2008 the chloride front of the baseline scenario moved as much as 2,360 ft farther east than the contour produced by the no-pumping scenario (fig. 28). 
Table 3. Pumping and recharge rates for each model scenario.

\begin{tabular}{|c|c|c|c|c|c|c|c|}
\hline \multirow{3}{*}{$\begin{array}{l}\text { Pumping or } \\
\text { recharge } \\
\text { type }\end{array}$} & \multirow{3}{*}{$\begin{array}{c}\text { Year } \\
\text { (stress } \\
\text { period) }\end{array}$} & \multicolumn{6}{|c|}{ Scenarios } \\
\hline & & $\begin{array}{c}\text { Existing } \\
\text { pumping } \\
\text { (baseline) }\end{array}$ & $\begin{array}{c}\text { No } \\
\text { pumping }\end{array}$ & $\begin{array}{l}\text { Double } \\
\text { Wichita } \\
\text { pumping }\end{array}$ & $\begin{array}{c}\text { No } \\
\text { irrigation } \\
\text { pumping }\end{array}$ & $\begin{array}{l}\text { Double } \\
\text { Wichita } \\
\text { pumping } \\
\text { and no } \\
\text { irrigation } \\
\text { pumping }\end{array}$ & $\begin{array}{c}\text { Increased } \\
\text { phase } 1 \\
\text { artificial } \\
\text { recharge }\end{array}$ \\
\hline & & \multicolumn{6}{|c|}{ Pumping or recharge rate (acre-feet per year)* } \\
\hline \multirow{19}{*}{$\begin{array}{c}\text { Municipal } \\
\text { pumping from } \\
\text { Wichita well } \\
\text { field }\end{array}$} & 1990 & $-37,440$ & 0 & $-74,880$ & $-37,440$ & $-74,880$ & $-37,440$ \\
\hline & 1991 & $-38,185$ & 0 & $-76,369$ & $-38,185$ & $-76,369$ & $-38,185$ \\
\hline & 1992 & $-39,939$ & 0 & $-79,879$ & $-39,939$ & $-79,879$ & $-39,939$ \\
\hline & 1993 & $-38,604$ & 0 & $-77,208$ & $-38,604$ & $-77,208$ & $-38,604$ \\
\hline & 1994 & $-34,120$ & 0 & $-68,240$ & $-34,120$ & $-68,240$ & $-34,120$ \\
\hline & 1995 & $-27,149$ & 0 & $-54,298$ & $-27,149$ & $-54,298$ & $-27,149$ \\
\hline & 1996 & $-27,085$ & 0 & $-54,169$ & $-27,085$ & $-54,169$ & $-27,085$ \\
\hline & 1997 & $-22,466$ & 0 & $-44,931$ & $-22,466$ & $-44,931$ & $-22,466$ \\
\hline & 1998 & $-18,602$ & 0 & $-37,203$ & $-18,602$ & $-37,203$ & $-18,602$ \\
\hline & 1999 & $-19,848$ & 0 & $-39,697$ & $-19,848$ & $-39,697$ & $-19,848$ \\
\hline & 2000 & $-20,926$ & 0 & $-41,853$ & $-20,926$ & $-41,853$ & $-20,926$ \\
\hline & 2001 & $-17,666$ & 0 & $-35,332$ & $-17,666$ & $-35,332$ & $-17,666$ \\
\hline & 2002 & $-19,284$ & 0 & $-38,568$ & $-19,284$ & $-38,568$ & $-19,284$ \\
\hline & 2003 & $-22,781$ & 0 & $-45,561$ & $-22,781$ & $-45,561$ & $-22,781$ \\
\hline & 2004 & $-23,852$ & 0 & $-47,704$ & $-23,852$ & $-47,704$ & $-23,852$ \\
\hline & 2005 & $-22,867$ & 0 & $-45,734$ & $-22,867$ & $-45,734$ & $-22,867$ \\
\hline & 2006 & $-23,117$ & 0 & $-46,234$ & $-23,117$ & $-46,234$ & $-23,117$ \\
\hline & 2007 & $-20,756$ & 0 & $-41,512$ & $-20,756$ & $-41,512$ & $-20,756$ \\
\hline & 2008 & $-19,921$ & 0 & $-39,842$ & $-19,921$ & $-39,842$ & $-19,921$ \\
\hline \multirow{19}{*}{$\begin{array}{l}\text { Irrigation } \\
\text { pumping from } \\
\text { model area }\end{array}$} & 1990 & $-66,860$ & 0 & $-66,860$ & 0 & 0 & $-66,860$ \\
\hline & 1991 & $-67,736$ & 0 & $-67,736$ & 0 & 0 & $-67,736$ \\
\hline & 1992 & $-31,846$ & 0 & $-31,846$ & 0 & 0 & $-31,846$ \\
\hline & 1993 & $-33,000$ & 0 & $-33,000$ & 0 & 0 & $-33,000$ \\
\hline & 1994 & $-59,647$ & 0 & $-59,647$ & 0 & 0 & $-59,647$ \\
\hline & 1995 & $-51,008$ & 0 & $-51,008$ & 0 & 0 & $-51,008$ \\
\hline & 1996 & $-50,116$ & 0 & $-50,116$ & 0 & 0 & $-50,116$ \\
\hline & 1997 & $-40,816$ & 0 & $-40,816$ & 0 & 0 & $-40,816$ \\
\hline & 1998 & $-60,030$ & 0 & $-60,030$ & 0 & 0 & $-60,030$ \\
\hline & 1999 & $-50,437$ & 0 & $-50,437$ & 0 & 0 & $-50,437$ \\
\hline & 2000 & $-69,753$ & 0 & $-69,753$ & 0 & 0 & $-69,753$ \\
\hline & 2001 & $-84,625$ & 0 & $-84,625$ & 0 & 0 & $-84,625$ \\
\hline & 2002 & $-77,576$ & 0 & $-77,576$ & 0 & 0 & $-77,576$ \\
\hline & 2003 & $-88,543$ & 0 & $-88,543$ & 0 & 0 & $-88,543$ \\
\hline & 2004 & $-50,670$ & 0 & $-50,670$ & 0 & 0 & $-50,670$ \\
\hline & 2005 & $-66,194$ & 0 & $-66,194$ & 0 & 0 & $-66,194$ \\
\hline & 2006 & $-82,961$ & 0 & $-82,961$ & 0 & 0 & $-82,961$ \\
\hline & 2007 & $-59,977$ & 0 & $-59,977$ & 0 & 0 & $-59,977$ \\
\hline & 2008 & $-51,113$ & 0 & $-51,113$ & 0 & 0 & $-51,113$ \\
\hline
\end{tabular}




\begin{tabular}{|c|c|c|c|c|c|c|c|}
\hline \multicolumn{8}{|c|}{ Table 3 continued } \\
\hline & & \multicolumn{6}{|c|}{ Scenarios } \\
\hline $\begin{array}{l}\text { Pumping or } \\
\text { recharge } \\
\text { type }\end{array}$ & Year & $\begin{array}{c}\text { Existing } \\
\text { pumping } \\
\text { (baseline) }\end{array}$ & $\begin{array}{c}\text { No } \\
\text { pumping }\end{array}$ & $\begin{array}{l}\text { Double } \\
\text { Wichita } \\
\text { pumping }\end{array}$ & $\begin{array}{c}\text { No } \\
\text { irrigation } \\
\text { pumping }\end{array}$ & $\begin{array}{l}\text { Double } \\
\text { Wichita } \\
\text { pumping } \\
\text { and no } \\
\text { irrigation } \\
\text { pumping }\end{array}$ & $\begin{array}{c}\text { Increased } \\
\text { phase } 1 \\
\text { artificial } \\
\text { recharge }\end{array}$ \\
\hline
\end{tabular}

\section{Pumping or recharge rate (acre-feet per year)*}

\begin{tabular}{cccccccc}
\hline & 1990 & 0 & 0 & 0 & 0 & 0 & 2,300 \\
& 1991 & 0 & 0 & 0 & 0 & 0 & 2,300 \\
& 1992 & 0 & 0 & 0 & 0 & 0 & 2,300 \\
& 1993 & 0 & 0 & 0 & 0 & 0 & 2,300 \\
& 1994 & 0 & 0 & 0 & 0 & 0 & 2,300 \\
Artificial & 1995 & 0 & 0 & 0 & 0 & 0 & 2,300 \\
recharge at & 1996 & 0 & 0 & 0 & 0 & 0 & 2,300 \\
Aquifer & 1997 & 0 & 0 & 0 & 0 & 0 & 2,300 \\
Storage and & 1998 & 0 & 0 & 0 & 0 & 0 & 2,300 \\
Recovery & 1999 & 0 & 0 & 0 & 0 & 0 & 2,300 \\
project phase & 2000 & 0 & 0 & 0 & 0 & 0 & 2,300 \\
1 sites & 2001 & 0 & 0 & 0 & 0 & 0 & 2,300 \\
& 2002 & 0 & 0 & 0 & 0 & 0 & 2,300 \\
& 2003 & 0 & 0 & 0 & 0 & 0 & 2,300 \\
& 2004 & 0 & 0 & 0 & 0 & 0 & 2,300 \\
& 2005 & 0 & 0 & 0 & 0 & 0 & 2,300 \\
& 2006 & 0 & 0 & 0 & 0 & 0 & 2,300 \\
& 2007 & 1,121 & 0 & 1,121 & 1,121 & 1,121 & 3,421 \\
& 2008 & 981 & 0 & 981 & 981 & 981 & 3,281 \\
\hline
\end{tabular}

*Negative values are rates of pumping out of the aquifer; positive values are recharge to the aquifer. 


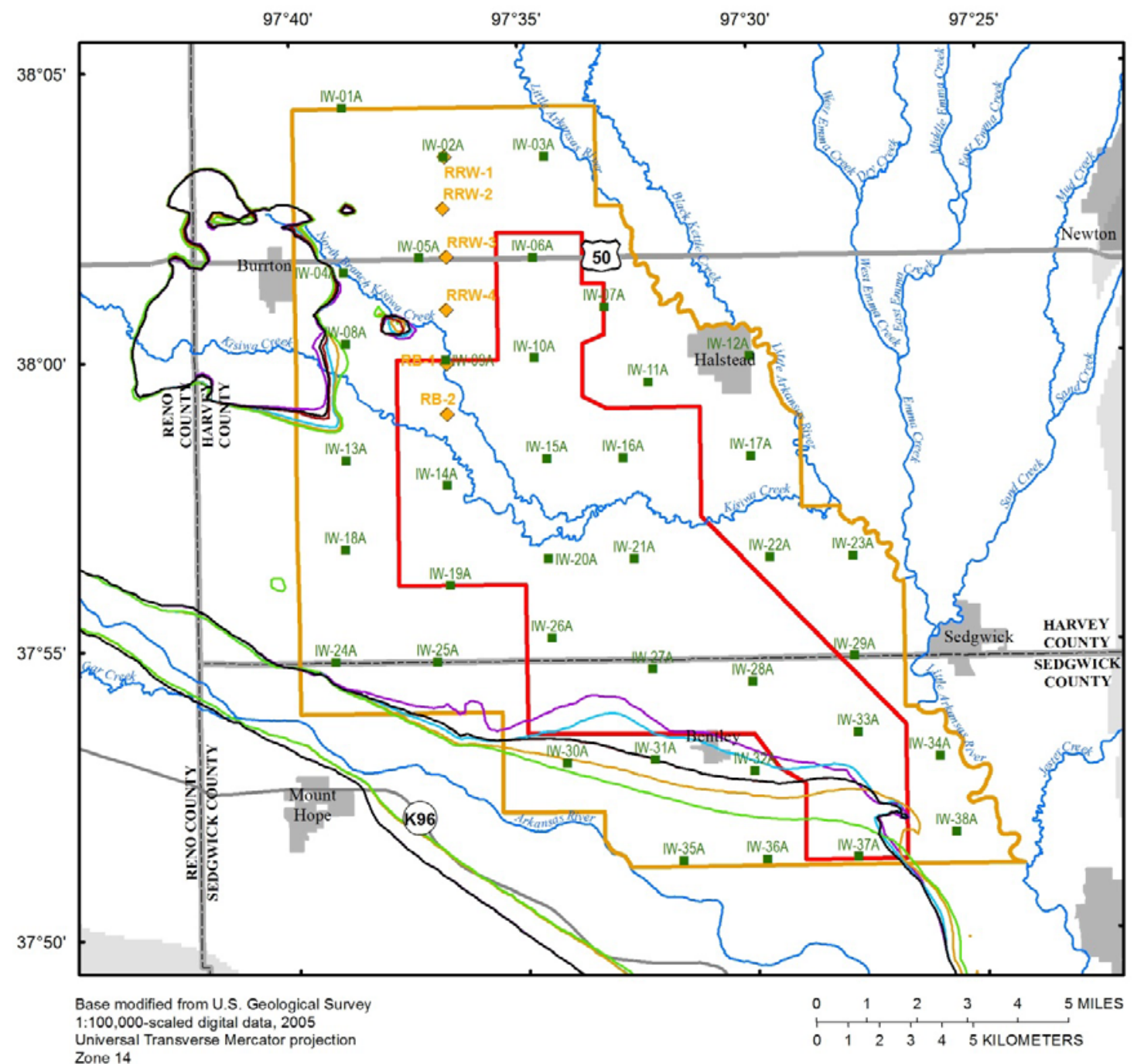

1:100,000-scaled digital data, 2005

Zone 14

Horizontal coordinate information is referenced to the

North American Datum of 1983 (NAD83)

\section{EXPLANATION}

Inactive areas in model layer 1

Central Wichita well field (WWF)

Basin storage area (BSA)

Simulated 250-mg/L-chloride fronts for six scenarios

Existing pumping (baseline)

- No pumping

Double Wichita municipal pumping

and existing irrigation pumping

Existing Wichita municipal pumping

and no irrigation pumping

Double Wichita municipal pumping

and no irrigation pumping

Increased Phase 1 artificial recharge

(same as baseline in southern part of map)

- Index monitoring well

$\diamond \quad$ Phase I recharge site

Figure 26. End of 2008 simulated 250-milligram per liter (mg/L)-chloride concentration contours for all scenarios, model layer 1. 


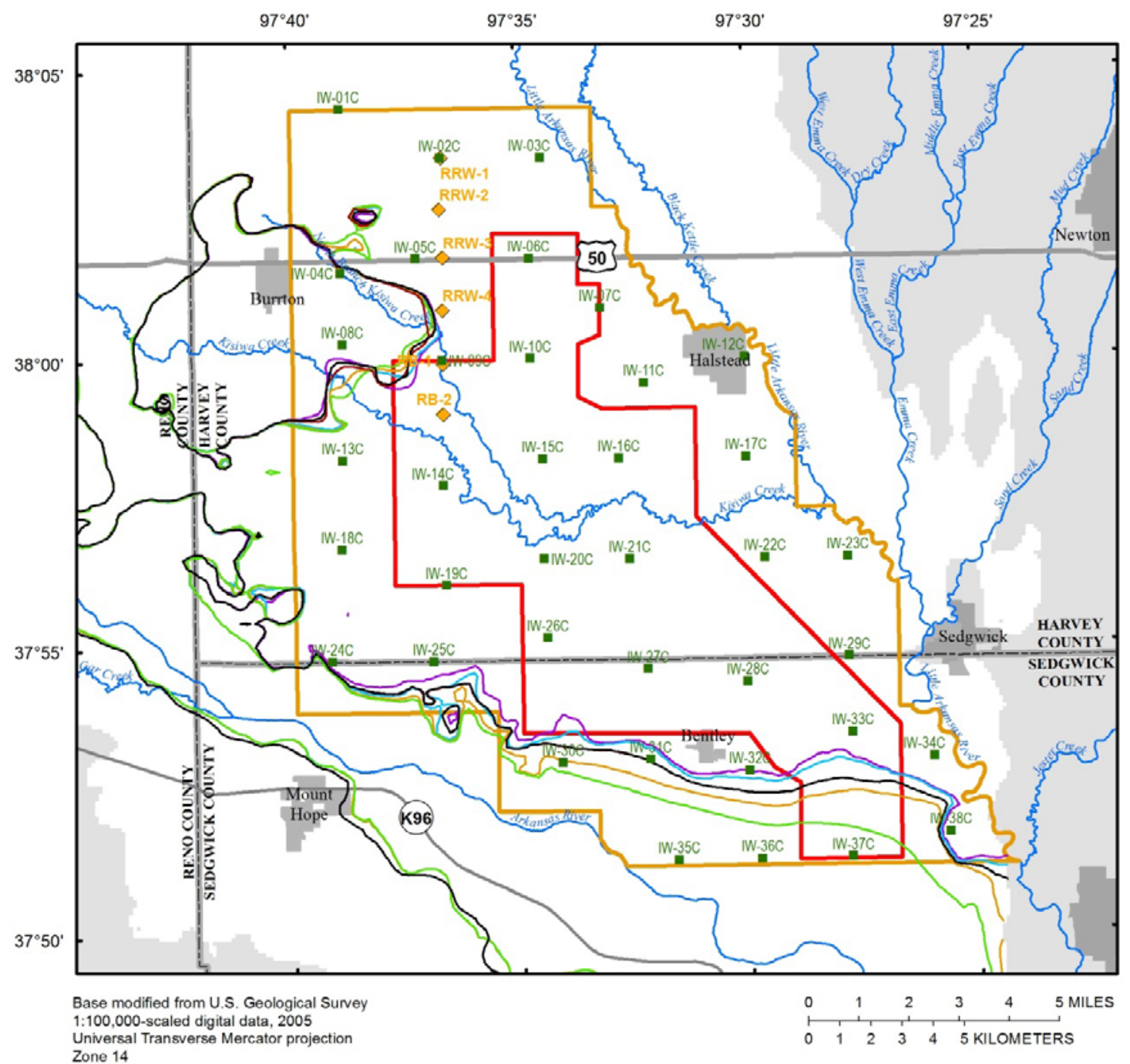

1:100,000-scaled digital data, 2005

Zone 14

Horizontal coordinate information is referenced to the

North American Datum of 1983 (NAD83)

\begin{tabular}{l} 
Inactive areas in model layer 2 \\
Central Wichita well field \\
Basin storage area (BSA) \\
$\begin{array}{l}\text { Bimulated } 250-\mathrm{mg} / \mathrm{L}-\text { chloride fronts for } \\
\text { six scenarios }\end{array}$ \\
\hline Existing pumping (baseline) \\
No pumping
\end{tabular}

EXPLANATION

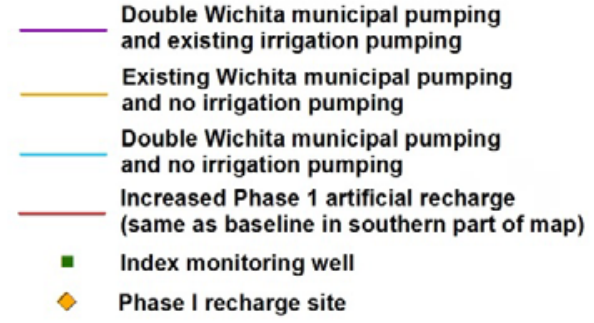

Figure 27. End of 2008 simulated 250-milligram per liter (mg/L)-chloride concentration contours for all scenarios, model layer 2. 


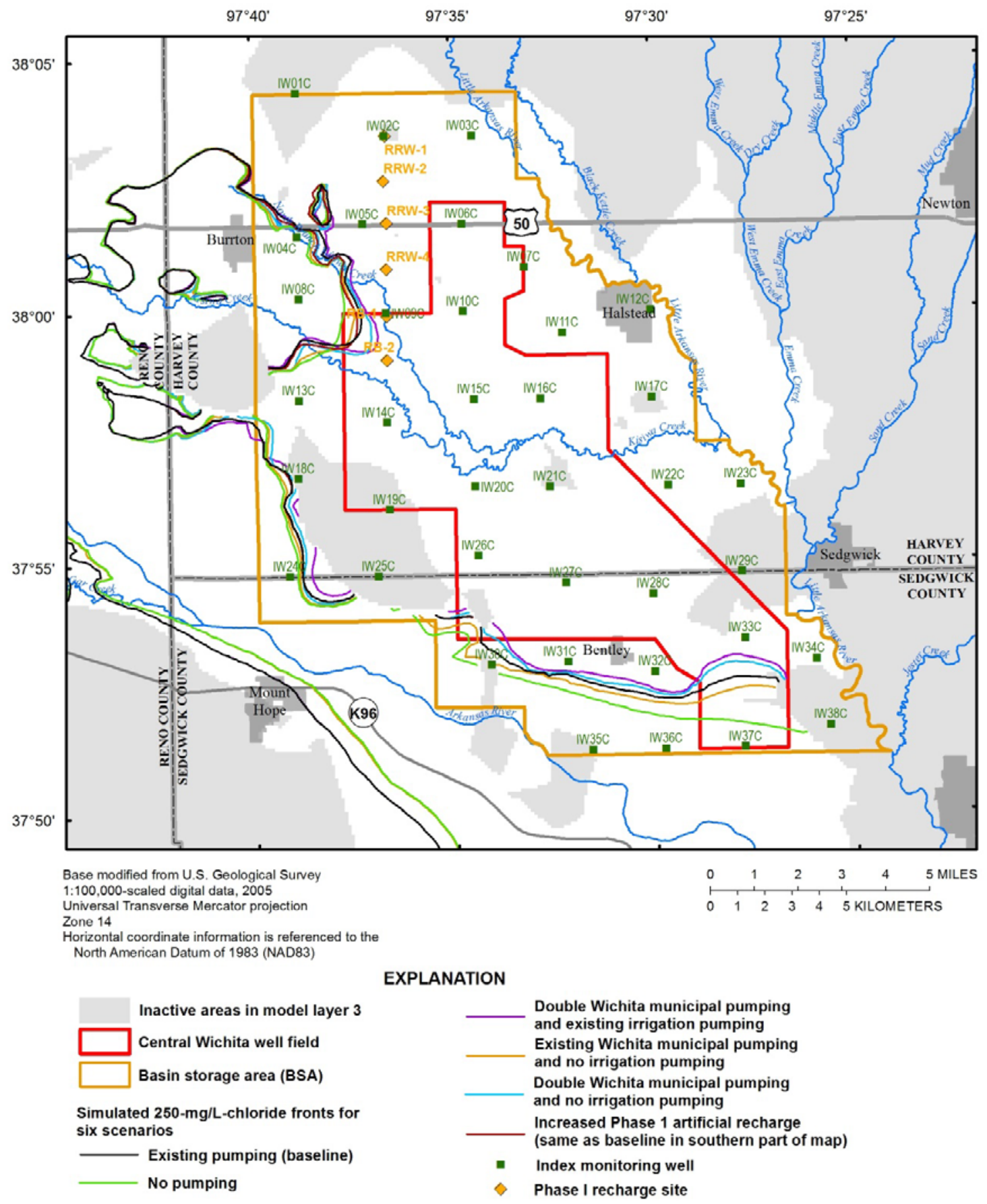

Figure 28. End of 2008 simulated 250-milligram per liter (mg/L)-chloride concentration contours for all scenarios, model layer 3. 
For this hypothetical scenario, simulated chloride concentrations near the Burrton plume in layer 1 dispersed farther into the areas surrounding the plume than in the baseline scenario (fig. 26). With the elimination of irrigation pumping, chloride concentrations in groundwater (that would have been removed from the Burrton plume by irrigation pumping) remained in model layer 1, and changed the hydraulic gradient between the Burrton plume area in layer 1 and surrounding areas and the two deeper layers.

At the end of the 2008 stress period, simulated groundwater levels and storage volume in the BSA are higher than those produced by the baseline scenario. On average, for this hypothetical scenario, water levels in the index wells were $5.05 \mathrm{ft}$ higher than in the baseline scenario, with a maximum difference in IW-21A of $16.45 \mathrm{ft}$ higher in the no pumping scenario than in the baseline scenario (table 4). The total simulated volume of water stored in the BSA was 73,700 acre-feet greater in this scenario than in the baseline scenario (table 5).

Simulation of this scenario demonstrated the possible (not affected by pumping or artificial recharge) movement of chloride in the study area. This scenario indicated that despite the lack of pumping, chloride transport from the Arkansas River and the Burrton plume was still towards the WWF area. Thus, reductions in pumping may not adequately stop the movement of chloride into the well field, and further actions, such as the ASR project or pumping from the Burrton plume and subsequent treatment of the water, may be necessary to avoid transport of chloride into the well field.

\section{Double Wichita Municipal Pumping and Existing Irrigation Pumping Scenario}

In this hypothetical scenario, the simulated rate of chloride transport was faster from the Arkansas River and from the Burrton plume towards the WWF compared to the rate simulated in the baseline scenario. Near the southern part of the well field, the chloride front in layer 1 moved northward toward and into the well field at about $810 \mathrm{ft} / \mathrm{yr}(150 \mathrm{ft} / \mathrm{yr}$ faster than in the baseline scenario), in layer 2 at about $870 \mathrm{ft} / \mathrm{yr}$ (90 ft/yr faster than in the baseline scenario), and in layer 3 at about $740 \mathrm{ft} / \mathrm{yr}(80 \mathrm{ft} / \mathrm{yr}$ faster than in the baseline scenario) (table 2). The chloride front on the main body of the Burrton plume moved southeast towards the well field in layer 1 at about $350 \mathrm{ft} / \mathrm{yr}(50 \mathrm{ft}$ slower than in the baseline scenario), in layer 2 at about $210 \mathrm{ft} / \mathrm{yr}(60 \mathrm{ft} / \mathrm{yr}$ faster than in the baseline scenario), and in layer 3 at about $440 \mathrm{ft} / \mathrm{yr}$ (130 ft/yr faster than in the baseline scenario) (table 2).

For this hypothetical scenario, a comparison of the movement of the simulated chloride front with the chloride front simulated in the baseline scenario indicated that the simulated chloride transport in the southern part of the well field near the Arkansas River was sensitive to city of Wichita pumping from the well field. In model layer 1,the chloride front simulated by this scenario extended farther into the well field than the chloride front simulated by the baseline scenario, and was approximately $2,800 \mathrm{ft}$ farther north by the end of the 2008 stress period (fig. 26). In layer 2, the chloride front was approximately $1,640 \mathrm{ft}$ farther north in this scenario than in the baseline scenario (fig. 27). In layer 3, the chloride front was approximately 1,250 ft farther north than the chloride front simulated by the baseline scenario (fig. 28).

In the Burrton plume area, the difference between the chloride front position in this hypothetical scenario and the baseline scenario was greater in layers 2 and 3 than in layer 1 (table 2, figs. 26, 27, and 28). In layer 1 , the chloride front from the baseline scenario was as much as $920 \mathrm{ft}$ farther southeast by the end of the 2008 stress period than the chloride front from this scenario (fig. 26). In layer 2, part of the chloride front was as much as $1,140 \mathrm{ft}$ farther in the direction of well field in this scenario than the chloride front simulated by the baseline scenario (fig. 27). In layer 3, the chloride front from this scenario was as much as $2,520 \mathrm{ft}$ farther into the well field by the end of the 2008 stress period than the chloride front simulated by the baseline scenario (fig. 28). 
Table 4. Simulated water level differences between hypothetical scenarios and the baseline scenario in index monitoring wells at the end of the 2008 stress period.

[Negative values mean water levels were lower than in the baseline scenario; positive values mean water levels were above those in the baseline scenario.]

\begin{tabular}{|c|c|c|c|c|c|}
\hline \multirow[t]{2}{*}{$\begin{array}{c}\text { Index } \\
\text { monitoring } \\
\text { well }\end{array}$} & $\begin{array}{l}\text { No pumping } \\
\text { scenario }\end{array}$ & $\begin{array}{l}\text { Double Wichita } \\
\text { pumping } \\
\text { scenario }\end{array}$ & $\begin{array}{l}\text { No irrigation } \\
\text { scenario }\end{array}$ & $\begin{array}{l}\text { Double Wichita } \\
\text { pumping and no } \\
\text { irrigation } \\
\text { pumping } \\
\text { scenario }\end{array}$ & $\begin{array}{c}\text { Increased phase } \\
1 \text { artificial } \\
\text { recharge } \\
\text { scenario }\end{array}$ \\
\hline & \multicolumn{5}{|c|}{ Difference in simulated water levels, hypothetical scenario minus baseline scenario (feet) } \\
\hline IW-01A & 0.08 & -0.03 & 0.07 & 0.04 & 0.05 \\
\hline IW-02A & 0.35 & -0.14 & 0.26 & 0.15 & 0.30 \\
\hline IW-03A & 2.01 & -0.87 & 1.31 & 0.52 & 0.79 \\
\hline IW-04A & 5.10 & -2.62 & 4.35 & 2.47 & 2.14 \\
\hline IW-05A & 5.85 & -3.85 & 5.65 & 4.02 & 4.81 \\
\hline IW-06A & 9.78 & -7.69 & 3.87 & -3.38 & 1.25 \\
\hline IW-07A & 8.61 & -6.69 & 3.54 & -2.75 & 0.61 \\
\hline IW-08A & 4.35 & -3.14 & 3.60 & 1.48 & 1.42 \\
\hline IW-09A & 4.85 & -8.75 & 4.97 & -1.34 & 2.71 \\
\hline IW-10A & 14.69 & -12.62 & 6.07 & -5.47 & 1.11 \\
\hline IW-11A & 9.69 & -8.11 & 3.84 & -3.72 & 0.36 \\
\hline IW-12A & 0.45 & -0.30 & 0.19 & -0.12 & 0.02 \\
\hline IW-13A & 2.19 & -2.28 & 1.68 & 0.23 & 0.22 \\
\hline IW-14A & 2.58 & -9.88 & 1.66 & -3.73 & 0.40 \\
\hline IW-15A & 13.60 & -13.18 & 6.01 & -5.69 & 0.53 \\
\hline IW-16A & 15.07 & -14.51 & 5.77 & -7.29 & 0.40 \\
\hline IW-17A & 4.56 & -3.29 & 2.01 & -1.14 & 0.07 \\
\hline IW-18A & 1.75 & -1.49 & 1.42 & 0.49 & 0.08 \\
\hline IW-19A & 4.28 & -5.15 & 2.89 & -0.68 & 0.18 \\
\hline IW-20A & 10.43 & -10.56 & 5.57 & -3.52 & 0.30 \\
\hline IW-21A & 16.45 & -15.51 & 6.62 & -7.23 & 0.25 \\
\hline IW-22A & 8.51 & -6.62 & 3.30 & -2.99 & 0.07 \\
\hline IW-23A & 1.35 & -0.82 & 0.61 & -0.20 & 0.01 \\
\hline IW-24A & 0.73 & -0.47 & 0.63 & 0.37 & 0.01 \\
\hline IW-25A & 1.94 & -1.83 & 1.45 & 0.28 & 0.05 \\
\hline IW-26A & 6.97 & -7.47 & 3.52 & -2.94 & 0.12 \\
\hline IW-27A & 9.44 & -10.49 & 4.08 & -5.58 & 0.08 \\
\hline IW-28A & 12.26 & -11.13 & 3.25 & -7.38 & 0.04 \\
\hline IW-29A & 2.40 & -1.77 & 0.77 & -0.97 & 0.01 \\
\hline IW-30A & 1.96 & -1.53 & 1.14 & -0.23 & 0.01 \\
\hline IW-31A & 2.04 & -1.65 & 1.10 & -0.38 & 0.01 \\
\hline IW-32A & 2.11 & -1.51 & 0.89 & -0.54 & 0 \\
\hline IW-33A & 2.12 & -1.59 & 0.64 & -0.92 & 0 \\
\hline IW-34A & 0.47 & -0.29 & 0.19 & -0.10 & 0 \\
\hline IW-35A & 0.45 & -0.27 & 0.26 & 0.02 & 0 \\
\hline IW-36A & 0.83 & -0.47 & 0.45 & 0 & 0.01 \\
\hline IW-37A & 1.01 & -0.58 & 0.49 & -0.07 & 0 \\
\hline IW-38A & 0.62 & -0.31 & 0.32 & 0.02 & 0 \\
\hline Average & 5.05 & -4.72 & 2.49 & -1.53 & 0.48 \\
\hline
\end{tabular}


Table 5. Simulated storage volume difference between hypothetical scenarios and baseline scenario in the basin storage area, end of 2008 stress period.

[BSA, Basin Storage Area; Negative values, less storage volume than in baseline scenario; Positive values, greater storage volume than in baseline scenario]

\begin{tabular}{|c|c|c|c|c|c|}
\hline \multirow[t]{2}{*}{$\begin{array}{l}\text { BSA } \\
\text { index cell }\end{array}$} & $\begin{array}{l}\text { No pumping } \\
\text { scenario }\end{array}$ & $\begin{array}{l}\text { Double Wichita } \\
\text { pumping } \\
\text { scenario }\end{array}$ & $\begin{array}{l}\text { No irrigation } \\
\text { scenario }\end{array}$ & $\begin{array}{l}\text { Double Wichita } \\
\text { pumping and no } \\
\text { irrigation } \\
\text { pumping } \\
\text { scenario }\end{array}$ & $\begin{array}{c}\text { Increased phase } \\
1 \text { artificial } \\
\text { recharge } \\
\text { scenario }\end{array}$ \\
\hline & \multicolumn{5}{|c|}{$\begin{array}{l}\text { Difference in simulated storage volumes, hypothetical scenario minus baseline scenario (acre- } \\
\text { feet) }\end{array}$} \\
\hline 1 & 121 & -39.6 & 95.2 & 63.9 & 72.3 \\
\hline 2 & 640 & -259 & 506 & 312 & 466 \\
\hline 3 & 557 & -233 & 378 & 168 & 210 \\
\hline 4 & 1,540 & -821 & 1,360 & 842 & 728 \\
\hline 5 & 2,060 & $-1,300$ & 1,710 & 697 & 1,220 \\
\hline 6 & 2,960 & $-2,230$ & 1,280 & -808 & 419 \\
\hline 7 & 488 & -354 & 205 & -134 & 40.6 \\
\hline 8 & 1,610 & $-1,220$ & 1,300 & 455 & 484 \\
\hline 9 & 3,300 & $-3,410$ & 2,380 & -509 & 1,060 \\
\hline 10 & 5,020 & $-4,300$ & 2,080 & $-1,870$ & 388 \\
\hline 11 & 2,650 & $-2,150$ & 1,070 & -940 & 118 \\
\hline 12 & 345 & -255 & 141 & -106 & 9.55 \\
\hline 13 & 970 & $-1,030$ & 736 & 74.4 & 108 \\
\hline 14 & 2,980 & $-3,860$ & 1,700 & $-1,470$ & 264 \\
\hline 15 & 5,340 & $-5,170$ & 2,310 & $-2,300$ & 210 \\
\hline 16 & 5,100 & $-4,690$ & 1,990 & $-2,270$ & 126 \\
\hline 17 & 1,820 & $-1,380$ & 788 & -514 & 29.9 \\
\hline 18 & 816 & -785 & 641 & 150 & 40.0 \\
\hline 19 & 2,050 & $-2,400$ & 1,310 & -504 & 92.4 \\
\hline 20 & 4,060 & $-4,100$ & 2,090 & $-1,450$ & 115 \\
\hline 21 & 6,340 & $-5,940$ & 2,480 & $-2,850$ & 91.4 \\
\hline 22 & 3,790 & $-3,150$ & 1,450 & $-1,480$ & 35.6 \\
\hline 23 & 521 & -346 & 216 & -123 & 2.91 \\
\hline 24 & 387 & -284 & 322 & 157 & 9.86 \\
\hline 25 & 958 & $-1,030$ & 667 & -16.3 & 25.0 \\
\hline 26 & 2,540 & $-2,680$ & 1,250 & $-1,070$ & 39.2 \\
\hline 27 & 4,600 & $-4,410$ & 1,680 & $-2,360$ & 37.8 \\
\hline 28 & 4,390 & $-3,980$ & 1,250 & $-2,510$ & 19.7 \\
\hline 29 & 910 & -681 & 290 & -379 & 2.65 \\
\hline 30 & 787 & -700 & 416 & -204 & 5.89 \\
\hline 31 & 1,080 & -931 & 508 & -339 & 5.23 \\
\hline 32 & 1,310 & $-1,080$ & 419 & -607 & 2.67 \\
\hline 33 & 786 & -583 & 245 & -326 & 1.12 \\
\hline 34 & 102 & -65.6 & 39.8 & -24.7 & 0.127 \\
\hline 35 & 139 & -90.7 & 81.2 & -0.0716 & 0.38 \\
\hline 36 & 247 & -153 & 126 & -16.4 & 0.457 \\
\hline 37 & 286 & -180 & 122 & -52.7 & 0.253 \\
\hline 38 & 117 & -61.2 & 60.0 & 0.259 & 0.105 \\
\hline Total BSA & 73,700 & $-66,300$ & 35,700 & $-22,300$ & 6,480 \\
\hline
\end{tabular}


In this scenario, chloride from the Arkansas River and from layers 2 and 3 from the Burrton plume moved farther toward the well field than in the baseline scenario (figs. 27 and 28) because the increase in pumping from the City wells caused increased hydraulic gradients between these areas and the well field. The increased hydraulic head gradient would increase groundwater-flow velocities and thus advective chloride transport into the well field. In layer 1, the Burrton plume did not move as far toward the well field in this scenario as in the baseline scenario (fig. 26), possibly because the increased pumping from layers 2 and 3 of the aquifer caused flow from layer 1 to layers 2 and 3, which carried some of the chloride into the deeper layers so it could not be transported horizontally within layer 1.

Simulated groundwater levels and storage volumes in the BSA at the end of the 2008 stress period in this scenario were lower than those in the baseline scenario (tables 4 and 5). On average, water levels in the index wells were $4.72 \mathrm{ft}$ lower in this scenario than in the baseline scenario; the largest difference was simulated for in IW-21, which was $15.51 \mathrm{ft}$ lower in this hypothetical scenario than in the baseline scenario. The total simulated volume of water stored in the BSA was 66,300 acre-feet less in this scenario than in the baseline scenario.

In this hypothetical scenario, doubling the rate of the city's pumping caused the farthest advancement of chloride towards and into the well field from both the Arkansas River and the Burrton plume (figs. 26, 27, 28). The doubling of pumping rates in 1990-1994 were nearly double the City's existing water rights of about 40,000 acre-feet. This scenario may be extreme in terms of the size of the pumping increase, but under drought conditions the city might increase pumping form the Equus Beds aquifer to supplement the water supply and to conserve Cheney Reservoir. If another extended drought occurs and water from Cheney Reservoir is not available to meet demands, results from this simulation offers an example of what could occur during a drought. Alternatively, decreased pumping along the Arkansas River would increase groundwater levels near the river, which would decrease hydraulic gradients towards the well field and that action may prevent further transport of chloride into the southern part of the well field area.

\section{Existing Wichita Municipal Pumping and No Irrigation Pumping Scenario}

In this hypothetical scenario, chloride transport from the Arkansas River near the southern part of the well field and from the Burrton plume towards the WWF was slower compared to the rate simulated in the baseline scenario. In model layer 1, the chloride front from the Arkansas River in moved northward at about $590 \mathrm{ft} / \mathrm{yr}$ ( $70 \mathrm{ft} / \mathrm{yr}$ slower than in the baseline scenario), in layer 2 at about $710 \mathrm{ft} / \mathrm{yr}$ (70 ft/yr slower than in the baseline scenario), and in layer 3 at about $620 \mathrm{ft} / \mathrm{yr}$ (40 ft/yr slower than in the baseline scenario) (table 2). The chloride front of the main body of the Burrton plume in layer 1 moved southeast toward the well field at a rate of about $510 \mathrm{ft} / \mathrm{yr}(110 \mathrm{ft} / \mathrm{yr}$ faster than in the baseline scenario), $100 \mathrm{ft} / \mathrm{yr}$ in layer 2 (50 ft/yr slower than in the baseline scenario), and $260 \mathrm{ft} / \mathrm{yr}$ in layer 3 (50 ft/yr slower than in the baseline scenario) (table 2).

In the southern part of the WWF, chloride from the Arkansas River did not move as far north toward the well field in this scenario as in the baseline scenario by the end of the 2008 stress period. In model layer 1, the simulated chloride front moved an average of 1,350 ft farther north toward the southern boundary of the well field in the baseline scenario than in this scenario (fig. 26). In layer 2, the baseline scenario chloride front moved approximately $1,370 \mathrm{ft}$ farther north than in this scenario (fig. 27). The chloride front moved approximately $810 \mathrm{ft}$ farther north in the baseline scenario than in this scenario by the end of the 2008 stress period in layer 3 (fig. 28). 
The southern part of the simulated Burrton plume in all layers moved farther toward the WWF in this scenario than in the baseline, but in layers 2 and 3 there are parts of the plume that extended farther toward the well field in the baseline scenario than in this scenario (figs. 26, 27, and 28). In layer 1, in the southern part of the plume, the chloride front moved as much as 2,090 ft farther southeast toward the WWF in this scenario than in the baseline scenario (fig. 26). In layer 2, in the southern part of the plume, the chloride front moved approximately 2,660 ft farther southeast in this scenario in one area, but northeast of that area part of the chloride front moved approximately $780 \mathrm{ft}$ farther south in the baseline scenario (fig. 27). In layer 3, part of plume extended farther southeast in this scenario, with the chloride front moving approximately 2,040 ft farther by the end of the 2008 stress period than in the baseline scenario, while in another part of the plume the chloride front in the baseline scenario moved $1,010 \mathrm{ft}$ farther east by the end of the 2008 stress period than it did in this scenario (fig. 28).

Simulated groundwater levels and storage volumes in the BSA for the 2008 stress period in this scenario were higher than those simulated in the baseline scenario (tables 4 and 5). On average, water levels in the index wells were $2.49 \mathrm{ft}$ higher in this scenario than in the baseline scenario; the largest difference was simulated for IW-21A, which was $6.62 \mathrm{ft}$ higher in this scenario than the water level in the baseline scenario. The total simulated volume of water stored in the BSA was 35,700 acre-ft greater in this scenario than in the baseline scenario.

For this hypothetical scenario, irrigation pumping was eliminated to test the effect that reduced irrigation pumping would have on the simulated groundwater flow and chloride transport. In times of low water availability, the irrigation withdrawals from the aquifer may need to be reduced to accommodate the senior water rights held by the city of Wichita. This scenario resulted in less chloride movement from the Arkansas River toward the southern part of the well field than what was simulated in the baseline scenario in all three model layers (figs. 26, 27, and 28), possibly because of less high chloride water being drawn into the aquifer from the river by nearby irrigation pumping, or lower hydraulic gradients between the river and the well field, or both. The differences in the shape and movement of the Burrton plume demonstrated the influence of irrigation pumping on the simulated chloride transport in this scenario when compared to the baseline scenario. In layer 1, the plume extended farther toward the well field (fig. 26) because irrigation pumping was eliminated from model layer 1, causing high chloride water that would have been pumped from the aquifer to remain, and larger hydraulic gradients between the plume area and the surrounding areas. Irrigation pumping was also eliminated from wells in layers 2 and 3, which may have caused less vertical chloride transport from layer 1 into layers 2 and 3, and thus more chloride remaining in layer 1 . In layers 2 and 3, the differences in the plume shape simulated in this scenario and in the baseline scenario were influenced by the absence of pumping from wells at various locations, depths, and pumping rates, resulting in the plume extending farther in this scenario than baseline in some areas and the baseline extending farther than this scenario in other areas of the plume (figs. 27 and 28). Return flow from irrigation was accounted for in the model by subtracting an estimated percentage of return flow from the irrigation pumping rate. However, the return flows most likely enter the aquifer over a wider area than single cell that a well is located in, and therefore may affect the influence that irrigation has over the groundwater flow and chloride transport.

\section{Double Wichita Municipal Pumping and No Irrigation Pumping Scenario}

In this hypothetical scenario, chloride moved from the Arkansas River and the Burrton plume toward the well field. The chloride front in layer 1 moved from the Arkansas River near the southern part of the well field north toward the well field at a rate of about $770 \mathrm{ft} / \mathrm{yr}(110 \mathrm{ft} / \mathrm{yr}$ faster than in the baseline scenario), in layer 2 at about $850 \mathrm{ft} / \mathrm{yr}(70 \mathrm{ft} / \mathrm{yr}$ faster than in the baseline scenario), and in layer 
3 at about $710 \mathrm{ft} / \mathrm{yr}(50 \mathrm{ft} / \mathrm{yr}$ faster than in the baseline scenario) (table 2). In layer 1, the chloride front of the main body of the Burrton plume moved southeasterly at a rate of about $500 \mathrm{ft} / \mathrm{yr}(100 \mathrm{ft} / \mathrm{yr}$ faster than in the baseline scenario), in layer 2 at about $150 \mathrm{ft} / \mathrm{yr}$ (the same as the rate estimate in the baseline scenario), and in layer 3 at about $400 \mathrm{ft} / \mathrm{yr}$ ( $90 \mathrm{ft} / \mathrm{yr}$ faster than in the baseline scenario) (table 2).

This scenario also resulted in simulated chloride transport from the Arkansas River further north in the southern part of the well field than in the baseline scenario. In layer 1, by the end of the 2008 stress period the chloride front moved an average of $1,870 \mathrm{ft}$ farther north in this scenario than in the baseline scenario (fig. 26). In layer 2, by the end of the 2008 stress period the chloride front moved an average of 1,240 ft farther north in this scenario than in the baseline scenario (fig. 27). In layer 3, by the end of the 2008 stress period the chloride front moved an average of $730 \mathrm{ft}$ farther north in this scenario than in the baseline scenario (fig. 28).

The Burrton plume moved farther in the direction of the well field in this scenario than in the baseline scenario. In layer 1, by the end of the 2008 stress period the chloride front moved as much as $1,740 \mathrm{ft}$ farther southeast toward the well field in this scenario than in the baseline scenario (fig. 26). In layer 2, by the end of the 2008 stress period the chloride front moved as much as $930 \mathrm{ft}$ farther southeast in this scenario than in the baseline scenario (fig. 27). In layer 3, by the end of the 2008 stress period the chloride front moved as much as $2,040 \mathrm{ft}$ farther southeast in this scenario than in the baseline scenario (fig. 28).

The lack of irrigation pumping in this scenario contributed to the movement of the plume in the same way as in the no irrigation scenario with existing municipal pumping, but the double Wichita municipal pumping from the well field of this scenario caused the plume to travel farther toward the well field in the deeper layers (figs. 27 and 28). The plume did not extend as far toward the well field in layer 1 in this scenario as in the no irrigation with existing Wichita municipal pumping scenario (fig. 26), possibly because of increased movement of chloride in the plume from the shallow layer into the deeper layers.

Simulated groundwater levels and storage volume in the BSA for the 2008 stress period for this scenario generally were lower than those in the baseline scenario (tables 4 and 5). On average, water levels in the index wells were $1.53 \mathrm{ft}$ lower in this scenario than in the baseline scenario, with the maximum difference in IW-28A, which was $7.38 \mathrm{ft}$ lower than in the baseline scenario. The total simulated volume of water stored in the BSA was 22,300 acre-ft less in this scenario than in the baseline scenario.

\section{Simulated Effects of Increased Phase 1 Artificial Recharge}

In this hypothetical scenario, 2,300 acre-ft per year of additional artificial recharge were applied to the ASR Phase 1 sites (fig 2). This value is based on the amount of water that the water-treatment plant can return and an estimated likely number of days per year the plant will be operated (Michael Jacobs, city of Wichita, oral commun., 2013). Dividing the 2,300 ac-ft/yr uniformly between the six sites increased water levels in the recharge basins above land surface, and far above the water levels of surrounding model cells. This indicated that the amount of recharge applied to those sites could not flow out of the recharge basin model cells as quickly as it was added. Consequently, an average of the artificial recharge rates in each basin from the 2007 and 2008 stress period in the baseline scenario was added to the recharge basins in this scenario for each stress period from 1990 through 2006 (with no additional recharge added to the basins in 2007 and 2008), and whatever remained of the 2,300 ac-ft/yr was divided evenly among the four injection wells (table 6). 
Table 6. Simulated artificial recharge rates for the Phase 1 sites in the increased artificial recharge scenario.

\begin{tabular}{|c|c|c|c|c|c|c|}
\hline \multirow{3}{*}{$\begin{array}{l}\text { Year } \\
\text { (Stress } \\
\text { period) }\end{array}$} & \multicolumn{6}{|c|}{ Artificial recharge site } \\
\hline & RRW-1 ${ }^{1}$ & RRW-2 ${ }^{1}$ & RRW-3 ${ }^{1}$ & RRW-4 $4^{1}$ & RB-1 $^{2}$ & RB-2 $^{2}$ \\
\hline & \multicolumn{6}{|c|}{$\begin{array}{c}\text { Recharge rate in increased artificial recharge scenario (acre-feet } \\
\text { per year) }\end{array}$} \\
\hline 1990 & 515.7 & 515.7 & 515.7 & 515.7 & 54.7 & 182.6 \\
\hline 1991 & 515.7 & 515.7 & 515.7 & 515.7 & 54.7 & 182.6 \\
\hline 1992 & 515.7 & 515.7 & 515.7 & 515.7 & 54.7 & 182.6 \\
\hline 1993 & 515.7 & 515.7 & 515.7 & 515.7 & 54.7 & 182.6 \\
\hline 1994 & 515.7 & 515.7 & 515.7 & 515.7 & 54.7 & 182.6 \\
\hline 1995 & 515.7 & 515.7 & 515.7 & 515.7 & 54.7 & 182.6 \\
\hline 1996 & 515.7 & 515.7 & 515.7 & 515.7 & 54.7 & 182.6 \\
\hline 1997 & 515.7 & 515.7 & 515.7 & 515.7 & 54.7 & 182.6 \\
\hline 1998 & 515.7 & 515.7 & 515.7 & 515.7 & 54.7 & 182.6 \\
\hline 1999 & 515.7 & 515.7 & 515.7 & 515.7 & 54.7 & 182.6 \\
\hline 2000 & 515.7 & 515.7 & 515.7 & 515.7 & 54.7 & 182.6 \\
\hline 2001 & 515.7 & 515.7 & 515.7 & 515.7 & 54.7 & 182.6 \\
\hline 2002 & 515.7 & 515.7 & 515.7 & 515.7 & 54.7 & 182.6 \\
\hline 2003 & 515.7 & 515.7 & 515.7 & 515.7 & 54.7 & 182.6 \\
\hline 2004 & 515.7 & 515.7 & 515.7 & 515.7 & 54.7 & 182.6 \\
\hline 2005 & 515.7 & 515.7 & 515.7 & 515.7 & 54.7 & 182.6 \\
\hline 2006 & 515.7 & 515.7 & 515.7 & 515.7 & 54.7 & 182.6 \\
\hline 2007 & 702.8 & 795.8 & 815.2 & 884.9 & 53.5 & 168.9 \\
\hline 2008 & 685.3 & 769.5 & 765.1 & 808.2 & 56.0 & 196.4 \\
\hline
\end{tabular}

${ }^{1}$ Injection well

${ }^{2}$ Recharge basin 
For this hypothetical scenario, the chloride transport from the Arkansas River near the southern part of the well field is similar to that of the baseline scenario. The distance between the chloride fronts of this scenario and baseline scenarios at the end of the 2008 stress period averaged less than $20 \mathrm{ft}$ in the area near the southern boundary of the WWF. Because the distance between the chloride fronts was so small, the estimated rate of movement of the chloride front toward the southern part of the well field from the Arkansas River was the same in this scenario as it was in the baseline scenario (table 2).

In the Burrton area, the chloride front in layer 1 moved southeasterly toward the well field at a rate of about $430 \mathrm{ft} / \mathrm{yr}(30 \mathrm{ft} / \mathrm{yr}$ faster than in the baseline scenario), in layer 2 at about $140 \mathrm{ft} / \mathrm{yr}(10 \mathrm{ft} / \mathrm{yr}$ slower than in the baseline scenario), and in layer 3 at about $250 \mathrm{ft} / \mathrm{yr}(60 \mathrm{ft} / \mathrm{yr}$ slower than in the baseline scenario) (table 2). The eastward movement of the Burrton plume was slowed by the simulation of additional artificial recharge at the Phase 1 sites. Simulated water levels were higher around the Phase 1 sites because of the increased artificial recharge, which caused the hydraulic gradient between the plume and the Phase 1 sites to decrease, thereby reducing the groundwater-flow velocity and advective transport in that direction. In layer 1, the chloride front in the baseline scenario was as much as about $630 \mathrm{ft}$ farther east than in this scenario at the end of the 2008 stress period (fig. 29). In layer 2, the chloride front in the baseline scenario was as much as about $860 \mathrm{ft}$ farther east than in the increased artificial recharge scenario by the end of the 2008 stress period (fig. 30, table 2). In layer 3, the chloride front in the baseline scenario was as much as about $890 \mathrm{ft}$ farther east than in this scenario by the end of the 2008 stress period (fig. 31, table 2).

Simulated groundwater levels and storage volume in the BSA were higher in this scenario than in the baseline scenario (tables 4 and 5). On average, water levels in the index wells were $0.48 \mathrm{ft}$ higher in this scenario than in the baseline scenario, with the maximum difference of $4.81 \mathrm{ft}$ higher in IW-05A. The total storage volume in the BSA was 6,480 acre-ft greater in this scenario than in the baseline scenario at the end of the 2008 stress period.

The simulation of this scenario demonstrates the effect of increased artificial recharge at the Phase 1 sites on the transport of chloride from the Burrton plume. Parts of the simulated Burrton plume that came nearest to Phase 1 recharge sites did not move as far east toward the well field in this scenario as in the baseline scenario (figs. 29, 30, and 31). Simulated water levels near the Phase 1 sites increased to less than $10 \mathrm{ft}$ below land surface, which is above the regulatory limit set by KDHE in the city's underground injection permit. The water level at RB2 (fig. 2) increased above ground surface in the 1993 stress period and remained above ground through the 2008 stress period, indicating that the rate of water flowing into the cell where the site is located was greater than the rate that water could flow into the adjacent cells. However, water has historically been recharged at this site and the water infiltrated into the aquifer; consequently, the discrepancy between simulated and observed water levels indicate changes to the groundwater-flow model at recharge basins are needed. 


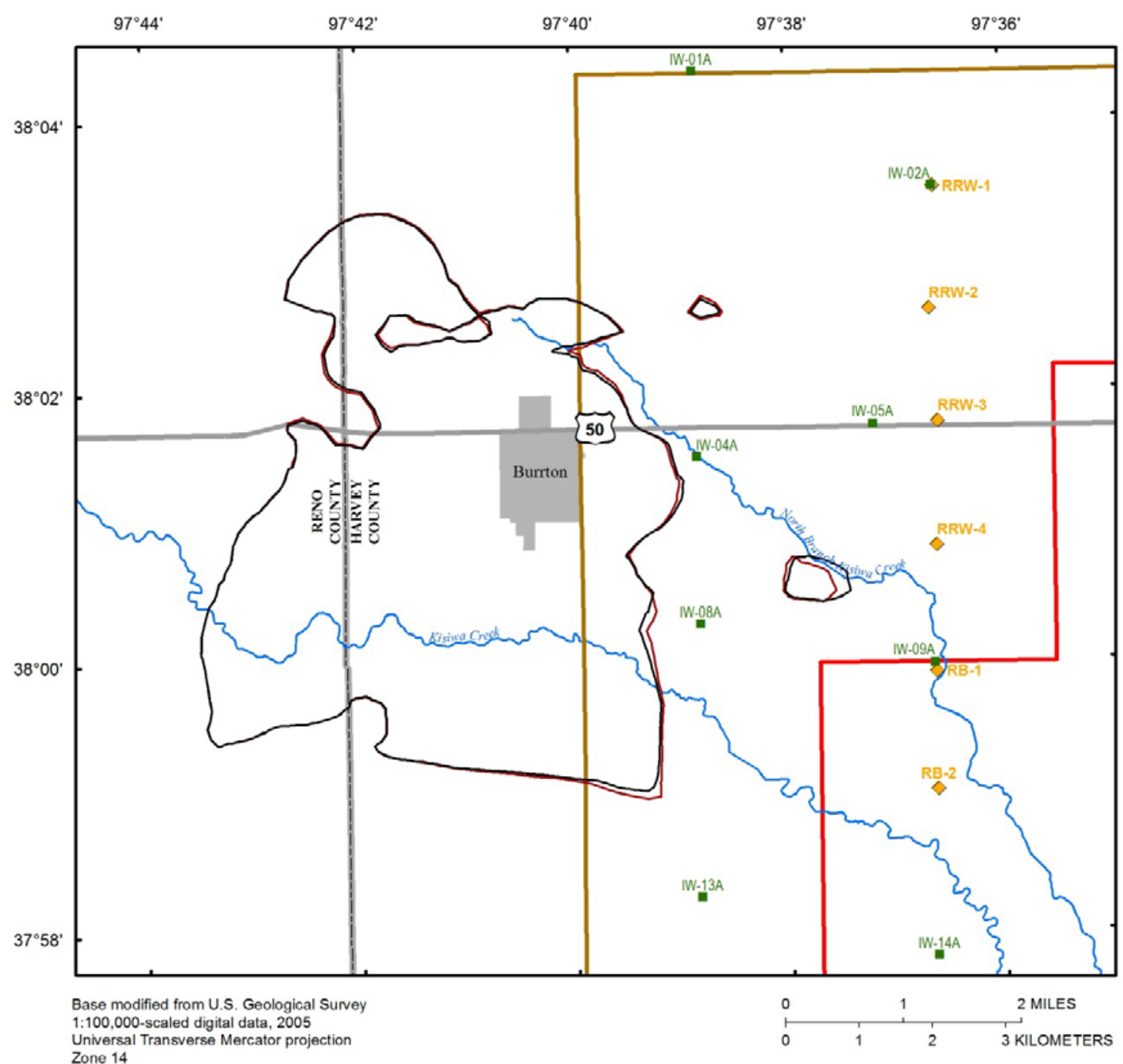

Universal Transverse Mercator projection

Zone 14

Horizontal coordinate information is referenced to the

North American Datum of 1983 (NAD83)

\section{EXPLANATION}

Central Wichita well field (WWF)

Basin storage area (BSA)

Simulated 250-mg/L-chloride fronts (2008)

Existing pumping (baseline)

Increased artificial recharge to the ASR

project phase 1 sites

- Index monitoring well

$\diamond \quad$ Phase I recharge site

Figure 29. Simulated 250-milligram per liter (mg/L)-chloride fronts near Burrton, Kansas for baseline and increased Phase 1 artificial recharge scenarios, end of 2008 stress period, model layer 1. 


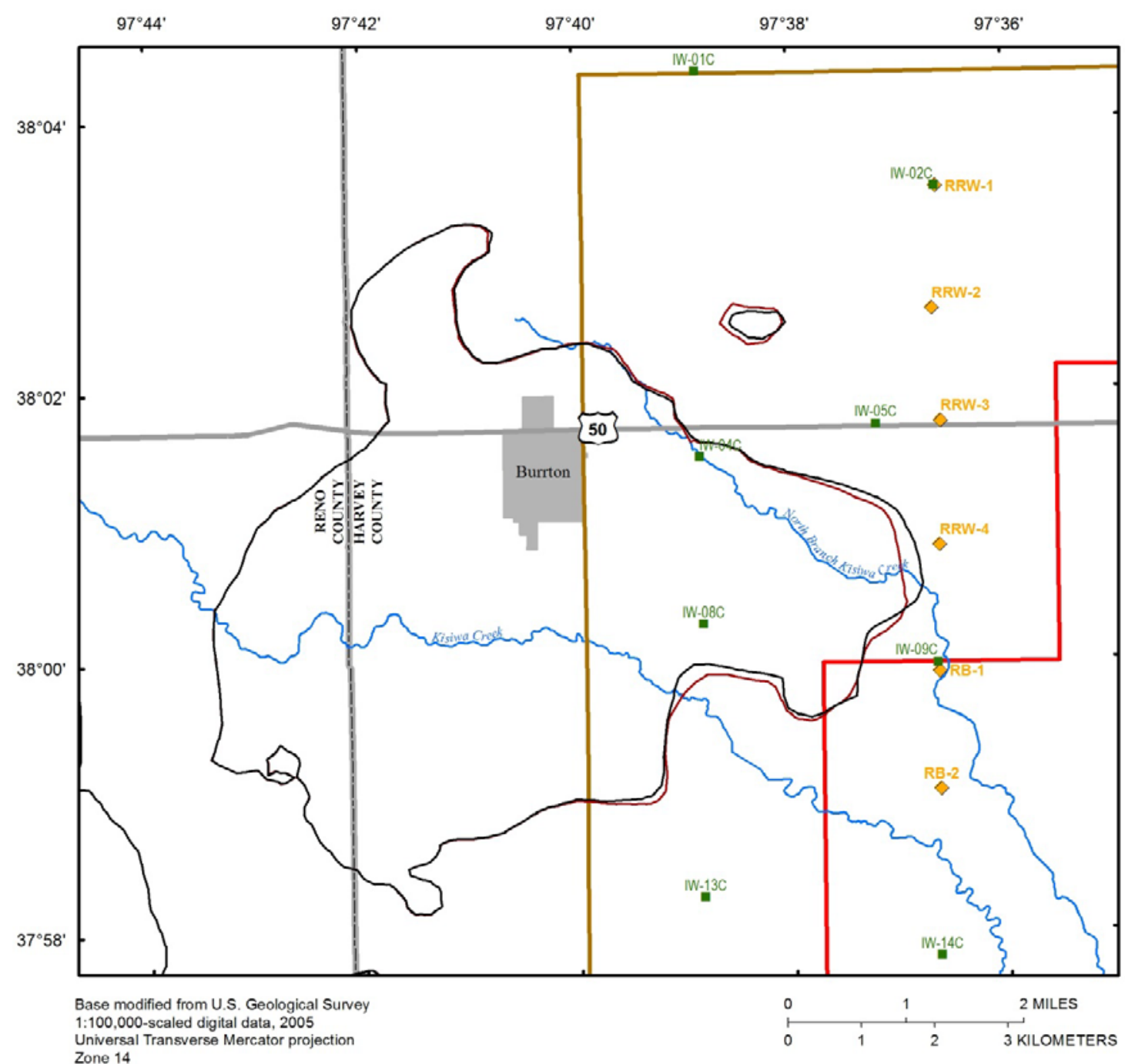

Universal Transverse Mercator projection

Zone 14

Horizontal coordinate information is referenced to the

North American Datum of 1983 (NAD83)

EXPLANATION

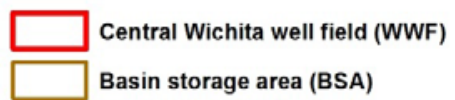

Simulated 250-mg/L-chloride front (2008)

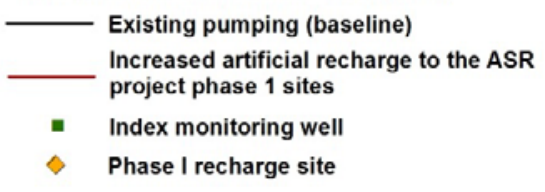

Figure 30. Simulated 250-miligram per liter (mg/L)-chloride fronts near Burrton, Kansas for baseline and increased Phase 1 artificial recharge scenarios, end of 2008 stress period, model layer 2. 


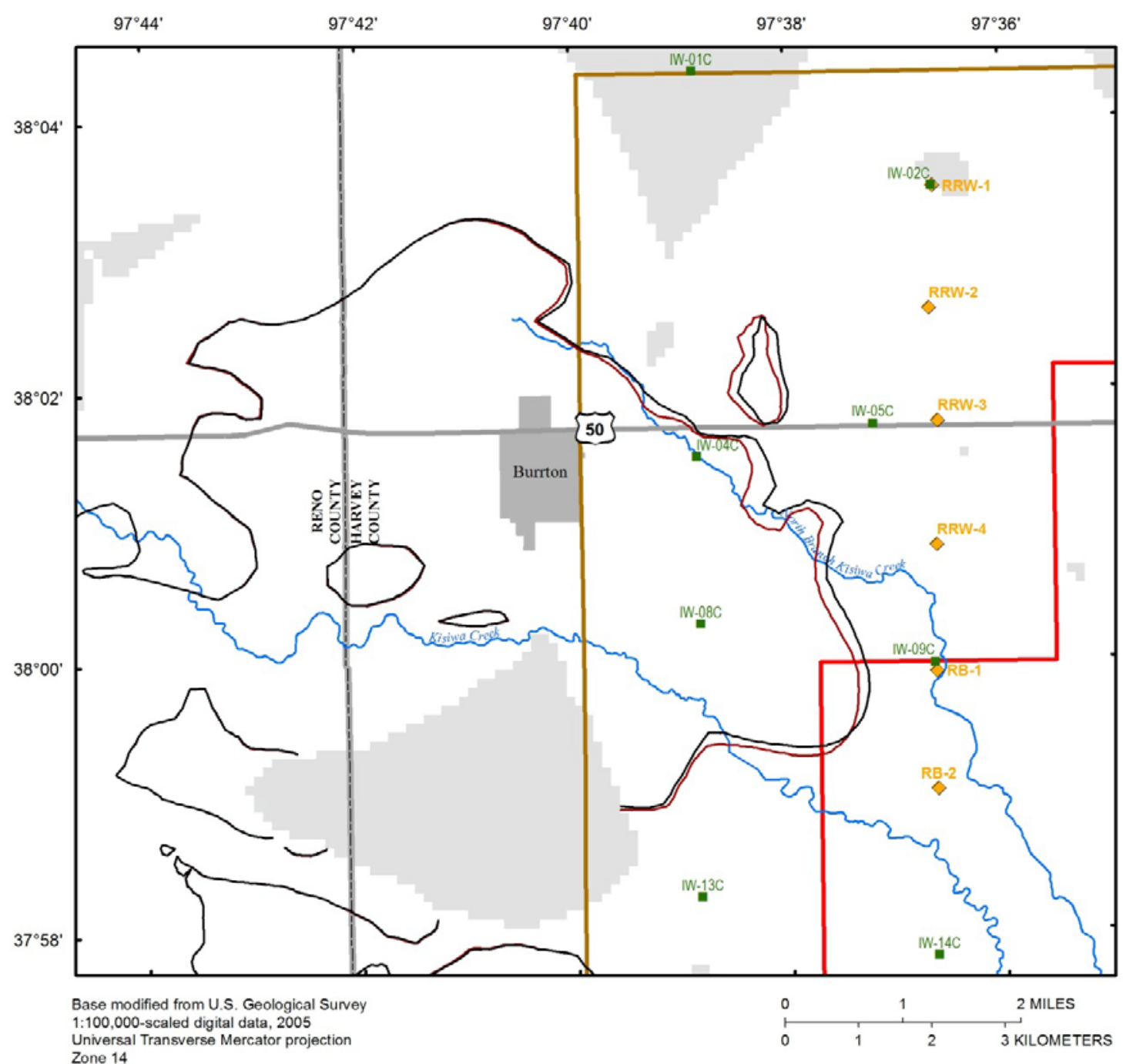

Universal Transverse Mercator projection

Zone 14

Horizontal coordinate information is referenced to the

North American Datum of 1983 (NAD83)

EXPLANATION

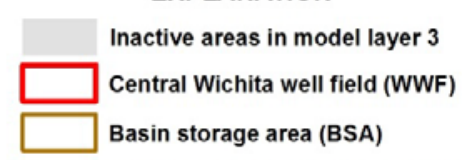

Simulated 250-mg/L-chloride fronts (2008)

- Existing pumping (baseline)

Increased artificial recharge to the ASR

project phase 1 sites

- Index monitoring well

$\diamond \quad$ Phase I recharge site

Figure 31. Simulated 250-milligram per liter (mg/L)-chloride fronts near Burrton, Kansas for baseline and increased Phase 1 artificial recharge scenarios, end of 2008 stress period, model layer 3. 


\section{Summary and Conclusions}

The Equus Beds aquifer is a primary water-supply source for the city of Wichita, Kansas. Water level declines because of municipal and agricultural pumping and periodic drought conditions have led to concern about the adequacy of the aquifer as a future water supply for Wichita. Chloride migration toward Wichita's central well field is another concern. Sources of chloride include oil-field brines that leaked from surface disposal pits and injection wells in the Burrton oil field area, municipal wastewater facility discharges, and mineralized water from the underlying Wellington Formation, and the high chloride waters from the Arkansas River to the southwest of the well field. In order to increase the volume of water stored in the aquifer and to protect the water quality from the chloride threats, in 2006 the city of Wichita began construction of the Equus Beds Aquifer Storage and Recovery project, to artificially recharge excess surface water flow from the Little Arkansas River into the aquifer for later recovery and to form a hydraulic barrier to retard movement of chloride in a brine plume near Burrton, Kansas.

In 2009, the USGS, in cooperation with the city of Wichita and as part of the Equus Beds Aquifer Storage and Recovery project, began a study to determine groundwater flow in the area between the Arkansas and Little Arkansas Rivers, which includes the Wichita well field and chloride transport from the Arkansas River and the Burrton oil field to the Wichita well field. A groundwater-flow model was developed using MODFLOW. Chloride transport was simulated for the Equus Beds aquifer using SEAWAT, a computer program that combines the groundwater-flow model MODFLOW-2000 and the solute-transport model MT3DMS. Chloride transport in the Equus Beds aquifer was simulated between the Arkansas and Little Arkansas Rivers near the Wichita well field. The chloride-transport model was used to simulate the period from 1990 through 2008 and the effects of five well pumping scenarios and one artificial recharge scenario. The chloride distribution in the aquifer for the beginning of 1990 was interpolated from groundwater samples from around that time, and the chloride concentrations in rivers for the study period were interpolated from surface water samples.

The SEAWAT model was used to compare chloride transport and groundwater flow between the existing-pumping and artificial-recharge scenario, four hypothetical well-pumping scenarios, and one hypothetical artificial-recharge scenario. The scenarios tested were (1) the existing 1990 through 2008 pumping and artificial recharge conditions, to serve as a baseline scenario for comparison with others; (2) no pumping in the model area, to demonstrate the chloride movement without the influence of well pumping; (3) double Wichita municipal pumping from the Wichita well field with existing irrigation pumping; (4) existing Wichita municipal pumping with no irrigation pumping in the model area; (5) double Wichita municipal pumping in the Wichita well field and no irrigation pumping in the model area; and (6) increasing artificial recharge to the Phase 1 Artificial Storage and Recovery project sites by 2,300 acre-ft per year.

In the existing pumping scenario, in the area between the Arkansas River and the southern boundary of the well field, the simulated chloride front moved north at an average rate of approximately $660 \mathrm{ft} / \mathrm{yr}$ in the shallow layer (layer 1), $780 \mathrm{ft} / \mathrm{yr}$ in the middle layer (layer 2), and $660 \mathrm{ft} / \mathrm{yr}$ in the deep layer (layer 3). The simulated chloride front moved toward the Wichita well field from the Burrton area at an approximate rate of $400 \mathrm{ft} / \mathrm{yr}$ in the shallow layer, $150 \mathrm{ft} / \mathrm{yr}$ in the middle layer, and $310 \mathrm{ft} / \mathrm{yr}$ in the deep layer.

In the no pumping scenario, chloride from the Arkansas River and the Burrton plume moved toward the Wichita well field. The chloride front from the Arkansas River near the southern part of the well field moved north toward the well field at an approximate average rate of $500 \mathrm{ft} / \mathrm{yr}$ in layer 1 (160 $\mathrm{ft} / \mathrm{yr}$ slower than in the baseline scenario), $570 \mathrm{ft} / \mathrm{yr}$ in layer $2(210 \mathrm{ft} / \mathrm{yr}$ slower than in the baseline scenario), and $510 \mathrm{ft} / \mathrm{yr}$ in layer 3 (150 ft/yr slower than in the baseline scenario). The simulated 
chloride front in the Burrton plume moved southeast toward the well field at a rate of approximately 520 $\mathrm{ft} / \mathrm{yr}$ in layer $1(120 \mathrm{ft} / \mathrm{yr}$ faster than in the baseline scenario), $70 \mathrm{ft} / \mathrm{yr}$ in layer $2(80 \mathrm{ft} / \mathrm{yr}$ slower than in the baseline), and $190 \mathrm{ft} / \mathrm{yr}$ in layer 3 (120 ft/yr slower than in the baseline scenario).

In the double Wichita municipal pumping, existing irrigation pumping scenario, chloride from the Arkansas River and from the Burrton plume moved toward the Wichita well field. The simulated chloride front from the Arkansas near the southern part of the well field moved north toward and into the well field at an approximate rate of $810 \mathrm{ft} / \mathrm{yr}$ in layer $1(150 \mathrm{ft} / \mathrm{yr}$ faster than in the baseline scenario), $870 \mathrm{ft} / \mathrm{yr}$ in layer 2 (90 ft/yr faster than in the baseline scenario), and $740 \mathrm{ft} / \mathrm{yr}$ in layer 3 (80 $\mathrm{ft} / \mathrm{yr}$ faster than in the baseline scenario). The simulated chloride front in the main body of the Burrton plume moved southeast towards the well field at a rate of approximately $350 \mathrm{ft} / \mathrm{yr}$ in layer $1(50 \mathrm{ft} / \mathrm{yr}$ slower than in the baseline scenario), $210 \mathrm{ft} / \mathrm{yr}$ in layer $2(60 \mathrm{ft} / \mathrm{yr}$ faster than in the baseline scenario), and $440 \mathrm{ft} / \mathrm{yr}$ in layer 3 (130 ft/yr faster than in the baseline scenario).

In the existing Wichita municipal pumping and no irrigation pumping scenario, chloride from the Arkansas River near the southern part of the well field and from the Burrton plume moved toward the Wichita well field. The simulated chloride front from the Arkansas River moved north at an approximate rate of $590 \mathrm{ft} / \mathrm{yr}$ in layer $1(70 \mathrm{ft} / \mathrm{yr}$ slower than in the baseline scenario), $710 \mathrm{ft} / \mathrm{yr}$ in layer $2(70 \mathrm{ft} / \mathrm{yr}$ slower than in the baseline scenario), and $620 \mathrm{ft} / \mathrm{yr}$ in layer $3(40 \mathrm{ft} / \mathrm{yr}$ slower than in the baseline scenario). The simulated chloride front of the main body of the Burrton plume moved southeast toward the well field at a rate of approximately $510 \mathrm{ft} / \mathrm{yr}$ in layer $1(110 \mathrm{ft} / \mathrm{yr}$ faster than in the baseline scenario), $100 \mathrm{ft} / \mathrm{yr}$ in layer 2 (50 ft/yr slower than in the baseline scenario), and $260 \mathrm{ft} / \mathrm{yr}$ in layer 3 (50 $\mathrm{ft} / \mathrm{yr}$ slower than in the baseline scenario).

In the double Wichita municipal pumping and no irrigation pumping scenario, chloride from the Arkansas River and the Burrton plume moved toward the well field. The simulated chloride front from the Arkansas River near the southern part of the well field moved north toward and into the well field at an average rate of approximately $770 \mathrm{ft} / \mathrm{yr}$ in layer 1 (110 ft/yr faster than in the baseline scenario), 850 $\mathrm{ft} / \mathrm{yr}$ in layer 2 (70 ft/yr faster than in the baseline scenario), and $710 \mathrm{ft} / \mathrm{yr}$ in layer $3(50 \mathrm{ft} / \mathrm{yr}$ faster than in baseline scenario). The simulated chloride front of the main body of the Burrton plume moved southeast at an average rate of approximately $500 \mathrm{ft} / \mathrm{yr}$ in layer $1(100 \mathrm{ft} / \mathrm{yr}$ faster than in the baseline scenario), $150 \mathrm{ft} / \mathrm{yr}$ in layer 2 (the same as the rate estimate in the baseline scenario), and $400 \mathrm{ft} / \mathrm{yr}$ in layer 3 (90 ft/yr faster than in the baseline scenario).

In the increased Phase 1 artificial recharge scenario, the chloride transport from the Arkansas River near the southern part of the well field was similar to that of the baseline scenario. The simulated chloride front moved at the same rate in the increased Phase 1 artificial recharge scenario as in the baseline scenario. In the Burrton area, the simulated chloride front moved southeast toward the well field at an approximate average rate of $430 \mathrm{ft} / \mathrm{yr}$ in layer $1(30 \mathrm{ft} / \mathrm{yr}$ faster than in the baseline scenario), $140 \mathrm{ft} / \mathrm{yr}$ in layer $2(10 \mathrm{ft} / \mathrm{yr}$ slower than in the baseline scenario), and $270 \mathrm{ft} / \mathrm{yr}$ in layer $3(60 \mathrm{ft} / \mathrm{yr}$ slower than in the baseline scenario). The eastward movement of the Burrton plume was slowed by the additional artificial recharge at the Phase 1 sites.

The average of simulated water levels from the end of the 2008 stress period in index monitoring wells in the Basin Storage Area was calculated for each scenario. Compared to the baseline scenario, the no pumping scenario was 5.05 feet higher, the double Wichita pumping with existing irrigation scenario was 4.72 feet lower, the no irrigation pumping with existing Wichita municipal pumping scenario was 2.49 feet higher, the double Wichita municipal pumping with no irrigation scenario was 1.53 feet lower, and the increased Phase 1 artificial recharge scenario was 0.48 feet higher.

The groundwater flow was simulated with a preexisting groundwater-flow model, which was not altered to calibrate the solute-transport model to observed chloride-concentration data. Therefore, in 
some parts of the model area, simulated and observed chloride concentration data match poorly. Most notably, chloride from the Arkansas River southwest of the well field moved northeast at a higher rate than the data indicate, and the simulated chloride front entered the most southern part of the well field in all scenarios simulated. Compared to the observed location of the chloride front interpreted from data collected in 2011, in the Arkansas River area the simulated chloride front moved from the river toward the well field about twice the rate of the chloride front interpreted from observed concentrations in layer 1 and about four times the rate of the chloride front interpreted from observed concentrations in layer 3. Achieving a better agreement between simulated and observed chloride data in the chloride-transport model may require changes to the groundwater-flow model. Future updates and recalibrations of the groundwater-flow and chloride-transport model will allow for changes in the groundwater-flow model parameters, including hydraulic conductivity, riverbed properties, and effective porosity, to accommodate the chloride-transport model in places where the chloride-transport model fit indicates problems with the groundwater flow.

Results of the modeling scenarios indicate that the Burrton chloride plume will continue moving toward the well field regardless of pumping in the area and that one alternative is to increase pumping from within the plume area to reverse the flow gradients and remove the plume. The modeling scenarios also indicate that the eastward movement of the Burrton plume could be slowed by additional artificial recharge at the Phase 1 sites. Decreasing pumping along the Arkansas River or increasing water levels in the aquifer near the river may retard the movement of chloride and may prevent further encroachment into the southern part of the well field area.

\section{References Cited}

Alkaeed, Othoman, Flores, Clariza, Jinno, Kenji, and Tsutsumi, Atsushi, 2006, Comparison of several references evapotranspiration methods for Itoshima Peninsula area, Fukuoko, Japan: Memoirs of the Faculty of Engineering, Kyushu University, v. 66, no. 1, p. 1-14. (Also available at http://civil.kyushuu.ac.jp/suiken/Lab/reserch/othoman.pdf)

Aucott , W.R., Myers, N.C., 1998, Changes in ground-water levels and storage in the Wichita well field area, south-central Kansas, 1940-98: U.S. Geological Survey Water-Resources Investigations Report 98-4141, 20 p. (Also available at http://pubs.er.usgs.gov/publication/wri984141.)

Bauder, T.A., Waskom, R.M., Sutherland, P.L., and Davis, J.G., 2011, Irrigation water quality criteria; Colorado State University Extension, Fact Sheet No. 0.506, accessed October 22, 2013 at http://www.ext.colostate.edu/PUBS/crops/00506.html

Bayne, C.K., 1956, Geology and ground-water resources of Reno County, Kansas: Kansas Geological Survey Bulletin 120, accessed October 6, 2011 at http://www.kgs.ku.edu/General/Geology/Reno/geog01.html.

Burns and McDonnell Engineering Consultants, 2008, Aquifer Storage and Recovery Project 2007 Accounting Report: Kansas City, Mo., Burns and McDonnell Engineering Consultants, [prepared for the Wichita Water and Sewer Department], [variously paged].

Burns and McDonnell Engineering Consultants, 2009, Aquifer Storage and Recovery Project 2008 Accounting Report: Kansas City, Mo., Burns and McDonnell Engineering Consultants, [prepared for the Wichita Water and Sewer Department], [variously paged].

Burrton Task Force, 1984, Proposed Burrton Intensive Groundwater Use Control Area: prepared for the Kansas State Board of Agriculture, Division of Water Resources, 103 p.

Cunningham, W.L., and Schalk, C.W., comps., 2011, Groundwater technical procedures of the U.S. Geological Survey: U.S. Geological Survey Techniques and Methods, book 1, chap. A1, 151 p. (Also available at http://pubs.er.usgs.gov/publication/ofr02293.) 
Desilva, Viraj, and Ary, Debra, 2011, Aquifer storage and recovery program remedies Wichita's groundwater problems: Journal of the American Water Works Association, v. 103, no. 6, p. 94-99.

Fetter, C.W., 1988, Applied hydrogeology ( $2^{\text {nd }}$ ed.): Columbus, Ohio, Merrill Publishing Co., 592 p. Halford, K.J., Hanson, R.T., 2002, User guide for the drawdown-limited, multi-node well (MNW) package for the U.S. Geological Survey's modular three-dimensional finite-difference ground-water flow model, versions MODFLOW-96 and MODFLOW-2000: U.S. Geological Survey Open-File Report 02-293, 33 p.

Hamon, W.R., 1961, Estimating potential evapotranspiration: Journal of the Hydraulics Division, American Society of Civil Engineers, v. 87, no. HY3, p. 107-120.

Hansen, C.V., 2007, Status of groundwater levels and storage volume in the Equus Beds aquifer near Wichita, Kansas, January 2003-January 2006: U.S. Geological Survey Scientific Investigations Report 2006-5321, 34 p. (Also available at http://pubs.er.usgs.gov/publication/sir20065321.) Hansen, C.V., and Aucott, W.R., 2001, Status of groundwater levels and storage volume in the Wichita well field area, south-central Kansas, 1998-2000: U.S. Geological Survey Water-Resources Investigations Report 00-4267, 27 p. (Also available at http://pubs.er.usgs.gov/publication/wri004267.)

Hansen, C.V., and Aucott, W.R., 2003, Status of groundwater levels and storage volume in the Equus Beds aquifer near Wichita, Kansas, January 2000-January 2003: U.S. Geological Survey WaterResources Investigations Report 03-4298, 36 p. (Also available at http://pubs.er.usgs.gov/publication/wri034298.)

Hansen, C.V., and Aucott, W.R., 2010, Status of groundwater levels and storage volume in the Equus Beds aquifer near Wichita, Kansas, January 2006 to January 2010: U.S. Geological Survey Scientific Investigations Report 2010-5231 , 47 p. (Also available at http://pubs.usgs.gov/sir/2010/5231/.)

Harbaugh, A.W., 2005, MODFLOW-2005, The U.S. Geological Survey modular ground-water model The ground-water flow process: U.S. Geological Survey Techniques and Methods, book 6, chapt. A16 [variously paged].

Harbaugh, A.W., Banta, E.R., Hill, M.C., and McDonald, M.G., 2000, MODFLOW-2000, the U.S. Geological Survey modular ground-water model - User guide to modularization concepts and the ground-water flow process: U.S. Geological Survey Open-File Report 00-92, 121 p.

Kansas Department of Agriculture, Division of Water Resources, 2007, Approval of application to appropriate water application file nos. 45567 through 45576, 46081, and 46578: Topeka, Kans., Kansas Department of Agriculture, Division of Water Resources.Kansas Geological Survey, 2011, County production: Kansas Geological Survey, accessed October 6, 2011 at http://www.kgs.ku.edu/PRS/petro/interactive.html.

Kelly, B.P., Pickett, L.L., Hansen, C.V., and Ziegler, A.C., 2013, Simulation of groundwater flow, effects of artificial recharge, and storage volume changes in the Equus Beds Aquifer near the city of Wichita well field 1935-2008: U.S. Geological Survey Scientific Investigations Report 2013-5042, 90 p. (Also available at http://pubs.er.usgs.gov/publication/sir20135042.)

Konikow, L.F., 2011, The Secret to Successful Solute-Transport Modeling: Groundwater, v. 49, no. 2, p. 144-159.

Konikow, L.F., Hornberger, G.Z., Halford, K.J., and Hanson, R.T., 2009, Revised multi-node well (MNW2) package for MODFLOW ground-water flow model: U.S. Geological Survey Techniques and Methods, book 30, chap. A6, 67 p. (Also available at http://pubs.er.usgs.gov/publication/tm6A30.) 
Lane, C.W., and Miller, D.E., 1965a, Geohydrology of Sedgiwick County, Kansas: Kansas Geological Survey Bulletin 176, 100 p. (Also available at http://www.kgs.ku.edu/General/Geology/Sedgwick/index.html.)

Lane, C.W., and Miller, D.E., 1965b, Logs of wells and test holes in Sedgwick County, Kansas: Kansas Geological Survey Special Distribution Publication 22, 175 p.

Langevin, C.D., Thorne, D.T., Jr., Dausman, A.M., Sukop, M.C., and Guo, Weixing, 2008, SEAWAT Version 4: A Computer Program for Simulation of Multi-Species Solute and Heat Transport: U.S. Geological Survey Techniques and Methods, book 6, chapt. A22, 39 p. (Also available at http://pubs.er.usgs.gov/publication/tm6A22.)

Lohman, S.W., and others, 1972, Definitions of selected ground-water terms-revisions and refinements: U.S. Geological Survey Water-Supply Paper 1988, 21 p. (Also available at http://pubs.er.usgs.gov/publication/wsp1988.)

McDonald, M.G., and Harbaugh, A.W., 1988, A modular three-dimensional finite-difference groundwater-flow model: U.S. Geological Survey Techniques of Water - Resources Investigations, book 6, chapt. A1, 576 p. (Also available at http://pubs.er.usgs.gov/publication/twri06A1.)

Myers, N.C., Haragadine, G.D., and Gillespie, J.B., 1996, Hydrologic and chemical interactions of the Arkansas River and the Equus Beds aquifer between Hutchinson and Wichita, south-central Kansas: U.S. Geological Survey Water-Resources Investigations Report 95-4191, 100 p. (Also available at http://pubs.er.usgs.gov/publication/wri954191.)

National Oceanic and Atmospheric Administration, 2008, Record of climatological observations Wichita, Kans.: National Climatic Data Center, accessed July 17, 2008, at http://www.ncdc.noaa.gov/oa/climates/stationlocator.html (Data is no longer at this URL; now available at $h t t p: / / w w w . n c d c . n o a a . g o v / c d o-w e b /$.

Pruitt, T., 1993, Arkansas River management improvement study-Modeling of chloride transport in the Equus Beds aquifer: U.S. Department of the Interior, Bureau of Reclamation Technical Report, 96 p.

Reed, T.B., and Burnett, R.D., 1985, Compilation and analyses of aquifer performance tests in eastern Kansas: U.S. Geological Survey Open-File Report 85-200, 125 p. (Available at http://pubs.er.usgs.gov/publication/ofr85200.)

Root, Ellen, Jones, Whit Schwarz, Bessie, Gibbons, Jack, 2004, Rainwater chemistry across the United States, accessed September 18, 2012 at http://www.people.carleton.edu/ bhaileab/environmentalgeology/RainWater.pdf.

Sawin, R.S., and Buchanan, R.C., 2002, Salt in Kansas: Kansas Geological Survey, accessed October 6, 2011 at http://www.kgs.ku.edu/Publications/pic21/pic21_1.html.

Schmidt, H.C.R., Ziegler, A.C., and Parkhurst, D.L., 2007, Geochemical effects of induced streamwater and artificial recharge on the Equus Beds aquifer, south-central Kansas, 1995-2004: U.S. Geological Survey Scientific Investigations Report 2007-5025, 58 p. (Also available at http://pubs.er.usgs.gov/publication/sir20075025.)

Schoewe, W.H., 1949, The geography of Kansas, part 2-Physical geography: Transactions of the Kansas Academy of Science, v. 52, no. 3, p. 261-333.

Sibson, Robin, 1981, A brief description of natural neighbor interpolation, Interpreting multivariate data: New York, John Wiley and Sons, p. 21-36.

Sophocleous, M.A., 1984, Groundwater-flow parameter estimation and quality modeling of the Equus Beds aquifer in Kansas, U.S.A.: Journal of Hydrology, v. 69, p. 197-222.

Spinazola, J.M., Gillespie, J.B., and Hart, R.J., 1985, Groundwater flow and solute transport in the Equus Beds area, south-central Kansas, 1940-79: U.S. Geological Survey Water-Resources 
Investigations Report 85-4336, 68 p. (Also available at

http://pubs.er.usgs.gov/publication/wri854336.)

Stramel, G.J., 1956, Progress report on the groundwater hydrology of the Equus Beds area, Kansas:

Kansas Geological Survey Bulletin 119, part 1, 59 p.

Stramel, G.J., 1962a, A review of the geology and hydrology of the Wichita well field: Wichita, Kans., city of Wichita Water Department, 29 p.

Stramel, G.J., 1962b, A preliminary review of artificial recharge potential in the area between

Hutchinson and Wichita, Kansas: Wichita, Kans., city of Wichita Water Department, 21 p.

Stramel, G.J., 1967, Progress report on the groundwater hydrology of the Equus Beds area, Kansas1966: Kansas Geological Survey Bulletin 187, part 2, 27 p.

U.S. Environmental Protection Agency, 2013, Secondary Drinking Water Regulations: Guidance for Nuisance Chemicals, accessed May 2, 2014, at URL

http://water.epa.gov/drink/contaminants/secondarystandards.cfm.

U.S. Geological Survey, 2014a, National Water Information System data available on the World Wide Web (USGS Water Data for the Nation), accessed May 2, 2014, at URL

http://nwis.waterdata.usgs.gov/ks/nwis/uv?cb_62614=on\&cb_00054=on\&format $=r d b \& p e r i o d=\& b e$ gin_date $=2010-01-01 \&$ end_date $=2013-12-3 \overline{1} \&$ site_no $=071 \overline{4} 4790$.

U.S. Geological Survey, 2014b, USGS water data for Kansas: U.S. Geological Survey National Water Information System, at http://waterdata.usgs.gov/ks/nwis

Walters, R.F., 1978, Land subsidence in central Kansas related to salt dissolution: Kansas Geological Survey Bulletin 214, 82 p. (Also available at

http://www.kgs.ku.edu/Publications/Bulletins/214/index.html.)

Warren, D.R., Blain, G.T., Shorney, F.L., and Klein, L.J., 1995, IRP_A case study from Kansas: Journal of the American Water Works Association, v. 87, no. 6, p. 57-71.

Whittemore, D.O., 2007, Fate and identification of oil-brine contamination in different hydrogeologic settings: Applied Geochemistry vol. 22 (10), 2099-2114.

Whittemore, D.O., 2012, Distribution and change in salinity in the Equus Beds aquifer in the Burrton Intensive Groundwater Use Control Area: Kansas Geological Survey Open-file Report 2012-1, 33 p.

Wichita, 2013, Wichita area future water supply: city of Wichita Utilities Department, accessed May 12, 2014, at

http://www.wichita.gov/Government/Departments/PWU/UtilitiesDocuments/WICHITA\%20AREA\%20 FUTURE\%20WATER\%20SUPPLY.pdf.

Williams, C.C., 1946, Ground-water conditions in Arkansas River valley in the vicinity of Hutchinson, Kansas: Kansas Geological Survey Bulletin 64, part 5, 72 p.

Williams, C.C., Lohman, S.W., 1949, Geology and groundwater resources of a part of south-central Kansas with a special reference to the Wichita municipal water supply: Kansas Geological Survey Bulletin 79, 455 p.

Zeller, D.E., ed., 1968, The stratigraphic succession in Kansas: Kansas Geological Survey, Bulletin 189, $81 \mathrm{p}$.

Zheng, C., and Wang, P.P., 1999, MT3DMS, A modular three-dimensional multi-species transport model for simulation of advection, dispersion, and chemical reaction of contaminants in groundwater systems, Documentation and user's guide: Vicksburg, Miss., U.S. Army Engineer Research and Development Center Contract Report SERDP-99-1, 202 p.

Ziegler, A.C., Christensen, V.G., and Ross, H.C., 1999, Baseline water-quality and preliminary effects of artificial recharge on groundwater, south-central Kansas, 1995-98: U.S. Geological Survey Water- 
Resources Investigations Report 99-4250, 74 p. (Also available at

http://pubs.er.usgs.gov/publication/wri994250.)

Ziegler, A.C., Hansen, C.V., and Finn, D.A., 2010, Water quality in the Equus Beds aquifer and the Little Arkansas River before implementation of large-scale artificial recharge, south-central Kansas, 1995-2005: U.S. Geological Survey Scientific Investigations Report 2010-5023, 143 p. (Also available at http://pubs.er.usgs.gov/publication/sir20105023.)

\section{Appendix 1. - Videos of the Simulated Chloride Fronts where Concentrations Reach 250 Milligrams per Liter, Equus Beds aquifer, Model Layers 1, 2, and 3, Stress Periods 1990-2008}

